\title{
Studies on gastrin
}

Citation for published version (APA):

Wesdorp, R. I. C. (1977). Studies on gastrin. [Doctoral Thesis, Maastricht University]. Rijksuniversiteit Limburg. https://doi.org/10.26481/dis.19770617rw

Document status and date:

Published: 01/01/1977

DOI:

10.26481/dis.19770617rw

Document Version:

Publisher's PDF, also known as Version of record

\section{Please check the document version of this publication:}

- A submitted manuscript is the version of the article upon submission and before peer-review. There can be important differences between the submitted version and the official published version of record.

People interested in the research are advised to contact the author for the final version of the publication, or visit the DOI to the publisher's website.

- The final author version and the galley proof are versions of the publication after peer review.

- The final published version features the final layout of the paper including the volume, issue and page numbers.

Link to publication

\footnotetext{
General rights rights.

- You may freely distribute the URL identifying the publication in the public portal. please follow below link for the End User Agreement:

www.umlib.nl/taverne-license

Take down policy

If you believe that this document breaches copyright please contact us at:

repository@maastrichtuniversity.nl

providing details and we will investigate your claim.
}

Copyright and moral rights for the publications made accessible in the public portal are retained by the authors and/or other copyright owners and it is a condition of accessing publications that users recognise and abide by the legal requirements associated with these

- Users may download and print one copy of any publication from the public portal for the purpose of private study or research.

- You may not further distribute the material or use it for any profit-making activity or commercial gain

If the publication is distributed under the terms of Article $25 \mathrm{fa}$ of the Dutch Copyright Act, indicated by the "Taverne" license above, 
Studies on gastrin 



\section{Studies on gastrin}

\section{Proefschrift}

ter verkrijging van de graad van Doctor in de

Geneeskunde aan de Rijksuniversiteit Limburg te

Maastricht op gezag van de rector magnificus

Prof.Dr. H.A. Tiddens en volgens besluit van

het College van Dekanen.

De openbare verdediging zal plaatsvinden op

vrijdag 17 juni 1977 des namiddags te 16.00 uur.

door

R.I.C. Wesdorp

geboren te Amsterdam 
Promotor

Co-Promotor

Co-Rieferenten
Prot.Dr. J.M Greep

: Prof. J.E. Fischer (Boston)

: Prot. Dr. A.J.C. Haex

Prof.Dr.P.J. Klopper

\section{Acknowledgements}

The clinical and experimental studies were performed at the Departments of Surgery and Medicine and at the Surgical Physiology Laboratory of the Massachusetts General Hospital and Harvard Medical School in Boston (U.S.A.).

The author gratefully acknowledges all persons who contributed to the realization of these studies. 
Women inspire us with the desire to do masterpieces, and always prevent us from carrying them out.

The picture of Dorian Gray, Oscar Wilde

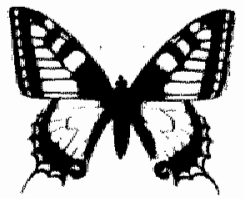

To Leondra, Anouschka Dimitri and Mischa 
The "Studies on gastrin" are based on the following published and to be published papers:

1. R.I.C. Wesdorp - J.E. Fischer

Plasma Gastrin and Acid secretion in patients with peptic ulceration. The Lancet II, 857-859, 1974.

2. H.A. Falcao - R.I.C. Wesdorp - J.E. Fischer

Gastrin levels and gastric acid secretion in anephric patients and in pattients with chronic and acute renal failure.

Journal of Surgical Research, 18: 107-111, 1975.

3. R.I.C. Wesdorp - J.E. Fischer

"Assay of Gastrin" in "Hormones in Human Plasma" Ed.

H.N. Antoniades, published by Harvard Medical Press, Boston, pp. 657-678, 1976.

4. A.I.C. Wesdorp - C.A. Wang - J.E. Fischer

Plasma and parathyroid tumor tissue gastrin and hyperparathyroidism.

The American Journal of Surgery, 131, 60-63, 1976.

5. R.I.C. Wesdorp - J.M. Funovics - H. Hirsch - J.E. Fischer

Characteristics of release of duodenal gastrin.

The American Journal of Surgery 133, 280-284, 1977.

6. J. Dretler - R.I.C. Wesdorp - J.E. Fischer - P.B. Soeters - A.M. Ebeid In vitro release of gastrin from isolated perfused antrum.

In press in The American Journal of Surgery, 1977.

7. R.I.C. Wesdorp - H.A. Falcao - P.B. Banks - J. Martino - J.E. Fischer Gastrin and gastric acid secretion in renal failure.

Submitted for publication. 


\section{Contents}

\section{Introduction}

- Historical notes and molecular heterogeneity

- Outline of investigations

Chapter I - Radioimmunoassay of gastrin

- Production of antisera

- Labeling of gastrin

- Assay technique

- Separation of bound and free antigen

- Specificity of Assay

- antibody specificity

- nature of gastrin used for labeling

- effect of environment

- incubation damage

- Sensitivity and Precision of Assay

- References

Chapter II - Physiology of gastrin

- Sites of gastrin production

- Rellease of gastrin in vivo

- Release of gastrin in vitro

- Release of duodenal gastrin

- Actions of gastrin

- Metabolism of gastrin

- References

Chapter III - Clinical aspects of gastrin

- Zollinger-Ellison Syndrome (Gastrinoma)

- Plasma and Parathyroid tumor tissue gastrin and hyperparathyroidism

- Gastrin and acid secretion in peptic ulceration

- Gastrin and acid secretion in renal failure

- References 



\section{Introduction}

\section{Historical notes and molecular heterogeneity}

In 1905 John S. Edkins, then a lecturer in physiology at St. Bartholomew's Medical College in London, reported to the Royal Society that he had found that extracts of hog gastric pyloric mucosa stimulated gastric secretion when injected intravenously into anesthetized cats (1). He named this stimulatory agent gastrin. The existence of this substance was debated for more than forty years, because contamination with histamine clouded the issue.

It was after 1938, when Komarov (2), at that time working at McGill University in Montreal, distinguished gastrin from histamine by precipitation with trichloroacetic acid and 1942, when Uvnäs (3) demonstrated that vagal impulses released gastrin, that the role of gastrin in stimulating gastric acid secretion was established.

Another 20 years were to pass before in 1964, Gregory and Tracy succeeded in isolating and purifying hog antral gastrin I and II (4) and with the help of Kenner and coworkers in determining its structure and later synthetizing gastrin I and II $(5,6)$. Both forms were found to be polypeptides with a molecular weight of about 2100 , containing 17 aminoacid residues ( $G-17)$, the difference between the two being a sulfated tyrosine molecule at the 12-position in gastrin II, a change which does not alter its physiologic activity. Gastrin heptadecapeptides or G-17 have been purified from antral mucosa of several species, including man, hog, dog, cat, sheep and $\operatorname{cow}(7,8)$ and found to differ by only one or two aminoacid substitutions.

All the biological actions of G-17 in all species appear to residue in the C-terminal tetrapeptide Try-Met-Asp-Phe. $\mathrm{NH}_{2}$, which is about one tenth as potent as G-17 (9). G-17 shares this C-terminal tetrapeptide with cholecystokinin and caerulein (10). The C-terminal aminoacid is blocked by an amide group and deamidation of $\mathrm{G}-17$ almost completely abolishes its physiologic activity. A pyroglutamyl group constitutes the amino terminus of the gastrin molecule.

This is thought to have a protective function, preventing destruction of circulating gastrin by serum aminopeptidases. The residues 1-13 do not appear to have any physiological function at the present time, except for enhancing the potency of the tetrapeptide, and protection of the tetrapeptide from inactivation by the liver (11).

In 1970, Yalow and Berson reported two immuno-reactive components of plasma (gastrin (12). One component had the characteristics of G-17 with a molecular weight of 2114 , the other component was more basic, had a molecular weight of approximately 7000 and was called "Big Gastrin" (BG). Subsequently, Gregory and Tracy (13) isolated a sulphated and unsulphated form of BG from Zollinger-Ellison Syndrome tumor tissue (BG I and II) and determined its aminoacid sequence (14). The aminoacid composition and sequence of $B G$ is shown in table $\|$, in which the different molecular forms of gastrin are abbreviated according to the number of aminoacid residues. $\mathrm{BG}$ or $\mathrm{G}-34$ consists of $\mathrm{G}-17$ plus an additional 17 aminoacid residues 


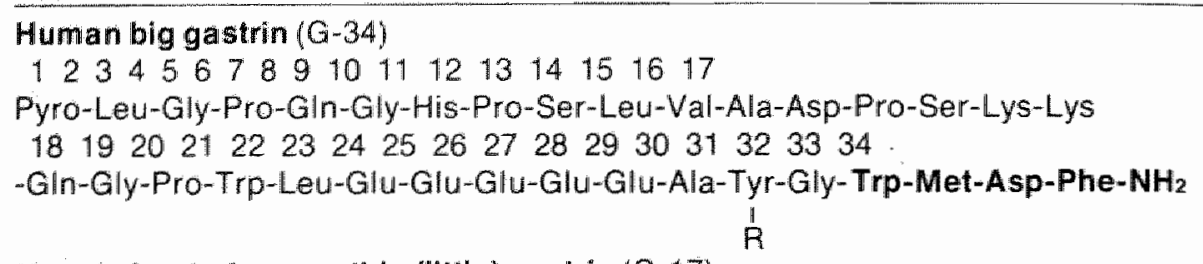

Human heptadecapeptide (little) gastrin (G-17)

$\begin{array}{llllllllllllllllll}1 & 2 & 3 & 3 & 4 & 5 & 6 & 7 & 8 & 9 & 10 & 11 & 12 & 13 & 14 & 15 & 16 & 17\end{array}$

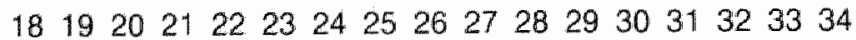

Pyro-Gly-Pro-Trp-Leu-Glu-Glu-Glu-Glu-Glu-Ala-Tyr-Gly-Trp-Met-Asp-Phe-NH2 $\stackrel{1}{\mathrm{R}}$

Human minigastrin ( $G-13$ )

$\begin{array}{llllllllllllll}1 & 2 & 3 & 4 & 5 & 6 & 7 & 8 & 9 & 10 & 11 & 12 & 13\end{array}$

$222324252627282930 \quad 313233 \quad 34$

Leu-Glu-Glu-Glu-Glu-Glu-Ala-Tyr-Gly-Trp-Met-Asp-Phe-NH2

!

Pentagastrin

3031323334

t-Boc-B-Ala-Trp-Met-Asp-Phe- $\mathrm{NH}_{2}$

Table 1. The chemically identified human gastrins in which gastrims are abbreviated according to the number of aminoacid residues that they contain. Numbering is froin amino(N)-terminal to carboxy(C)-terminal.

The symthetic pentapeptide or pentagastrin is illustrated as well.

covalently linked to the $\mathrm{N}$-terminus of $\mathrm{G}-17$ by a lysy!-glutaminyl bond that can be split by trypsin in G-17 with a quantitative recovery of immunoreactivity. Yalow and Berson's fractionation studies $(15,16)$ resulted in isolation of an even larger molecular form, what they called "Big-Big-Gastrin" (BBG), and which is found to comprise $1-2 \%$ of serum immunoreactive gastrin in patients with ZES and probably is a major component of fasting plasma gastrin (17). However $B B G$ has not been characterized chemically or biologically yet.

Also isolated from ZES tumor tissue by Gregory and Tracy (18) is a smaller form of gastrin known as "Mini"' gastrin which has 13 aminoacid residues (G-13). $\mathrm{G}-13$ is the $\mathrm{C}$-terminal tridecapeptide fragment of the bigger forms of gastrin (table l). The non-sulphated forms usually predominate in all three human gastrins (G-13, G-17 and G-34) in the proportion of 2/1 (14). Stadil and Rehfeld (19) isolated still another molecular form, what they called Component-I, and which is supposed to have a molecular size like pro-insulin.

Pentagastrin which is used for gastric acid stimulation studies is a synthetic analogue of the $\mathrm{C}$-terminal tetrapeptide, containing 5 aminoacid residues (table l).

Little is known about the significance of gastrin molecular heterogeneity and the biological effects of the different gastrins. It is known that there is difference in catabolism and potency of the different molecular forms: the bigger molecules have a longer half-life and are less potent than the smaller forms, an 
observation which could explain why bigger gastrin molecules predominate in determinations of basal plasma gastrin.

In fasting human plasma, G-34 and BBG predominate, while stimulation by feeding leads to an increased release of $\mathrm{G}-17$ and $\mathrm{G}-34$, but the concentration of $B B G$ does not appear to change on feeding and at the present time there is no information concerning its biological activity.

The gastrin secreting cells (G-cells) are found to be specialized endocrine cells, which belong to the so called "APUD-cell-family" as first described by Pearse in $1968(20)$.

The APUD-cells derive their name from the initial letters of their first three and mast important properties namely a high content of Amine, the capacity for amine Precursor Uptake and the presence of aminoacid Decarboxylase for the conversion of the aminoacid precursors to amines.

These APUD-cells have common cytochemical and ultrastructural characteristics, clearly related to the synthesis of polypeptides and amines and are widely distributed in the body. According to Pearse they originate from the embryonal neuroectoderm and migrate to the developing gut.

With advanced cytochemical techniques and immunofluorescence studies we are now only just beginning to recognize the magnitude of the gut as an endocrine organ, as we know now that a spectrum of endocrine cells stretches from oesophagus to rectum. From the gastro-intestinal hormones synthetized and secreted by these cells, gastrin is one of the first isolated and synthetized, but apart from its molecular heterogeneity, relatively little is known about the physiological and clinical significance of gastrin. It is the most potent stimulator of gastric acid secretion and probably has a trophic effect on intestinal mucosa, but only in the Zollinger-Ellison Syndrome there is a direct relationship between high gastrin levels, high acid secretion and peptic ulceration.

\section{Outline of investigations}

The main purpose of the present study is to provide additional clinical and experimental data as a contribution to unravel the physiological and clinical significance of gastrin.

Schematically, this thesis is devided into four chapters

In Chapterl, the development of the gastrin-radioimmunoassay is described and more specific the characteristics of the assay, as it was developed in the laboratory of Surgical Physiology of the Massachusetts General Hospital in Boston.

In Chapter III, Physiology of gastrin, the actions, sites of production and the relaese of gastrin in vivo are reviewed, while in an adapted perfusion set-up the release of gastrin in vitro from isolated rat antra is studied and the characteristics discussed. In acute experiments in dogs, the characteristics of release of duodenal gastrin are studied and compared with the characteristics of antral gastrin release.

Chapter III, Clinical aspects of gastrin, will deal very briefly with the ZollingerEllison Syndrome as an introduction to a clinical study concerning plasma and parathyroid tumor tissue gastrin in hyperparathyroidism. Furthermore, in two prospective clinical studies the role of gastrin in peptic ulceration and in different forms of renal failure is studied.

Chapter IV will present a general discussion and summary of the data presented in these studies on gastrin. 


\section{Labeled} hormone

(F)

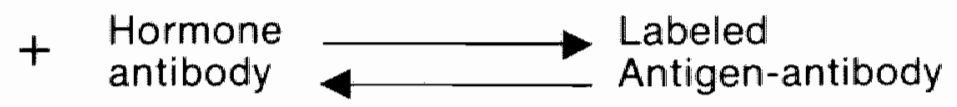

(B)

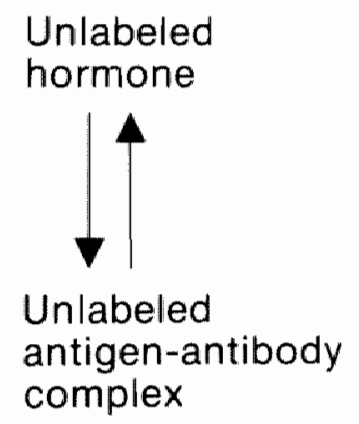




\section{Chapter I}

\section{Radioimmunoassay of gastrin}

Since biologic assays are not sensitive enough to measure physiologic basal concentrations of gastrin in peripheral serum $(21,22)$, the availabillity of purified human and porcine and later of synthetic gastrin rapidly stimulated the development of radioimmunoassays for gastrin in the early sixties.

The principle of the assay, as first reported by Berson and Yalow (23) for the measurement of insulin in 1959, is based on the reversible binding of a labeled hormone to its specific antibody and the ability of the unlabeled hormone to compete in this reaction and to displace the labeled antigen from antibody (Figure 1).

The reaction results in the formation of a labeled antigen-antibody complex. If unlabeled hormone is added, it competes for the fixed amounts of antibody and forms an unlabeled antigen-antibody complex, thereby reducing the amount of available antibody bound to labeled hormone. The more unlabeled hormome added, the less labeled hormone will be bound to the antibody and vice versa. After incubation of a mixture of labeled hormone, specific antibody and unlabeled hormone, in known standard sollutions or unknown samples, the labeled antigen-antibody complex (B-bound) is separated from the unbound or free labeled hormone (F-free).

The radioactivity in each fraction is counted in a gamma counter and the ratio of the bound to free labeled hormone ( $B / F$ ratio) is expressed as a function of the concentration of unlabeled hormone. A low ratio indicates that a small amount of labeled hormone is bound to the antibody and a large amount of hormone is present in the original unknown plasma. A high B/F ratio indicates the opposite.

Comparison of the $B / F$ ratio with a standard dose-response curve gives the exact result, usually in nanograms or picograms/ml. The unknown samples are prepared in the same diluent of hormone free plasma containing the same concentrations of antibody and labeled hormone as present in the standard solutions and incubated simultaneously and under the same conditions as the standard solutions, known as the standard curve.

\section{Production of antisera}

In the development of the gastrin radioimmunoassay, the production of appropriate antisera has been the limiting factor. Owing to its small size (M.W. 2114), the gastrin heptadecapeptide (G-17) is only weaklly antigenic. Until recently, it was considered that a molecular weight of at least 3000 was necessary for a protein to be antigenic. The demonstration that small. unconjugated peptides for example, oxytocin (24) could st mulate antibody production "has shown that this is not necessarily so. However, the antigenety of small peptides can be enhanced by covalent coupling to a larger protein molecule (25), coating with latex particles (26) or carbon (27) or by the use of crude preparations in which impurities may act as a carrier for the antigen. 
Another potential problem with antigastrin antibodies is the cross reactivity with another intestinal hormone, cholecystokinin $(\mathrm{CCK})$, which shares a common carboxyterminal tetrapeptide with gastrin (10). It has been shown, that this $\mathrm{C}$-terminal tetrapeptide that contains all the physiologic properties of gastrin, is the most important antigenic part of the gasirin molecule $(25,28,29)$ as well.

At the present time, two techniques have been used with equal success. Firstly, the method reported by McGuigan (30) in 1968. He had produced rabbit antiserum to synthetic human $\mathrm{G}-17$, containing the residues 2-17 ( $\mathrm{SHG} 2-17$ ) conjugated to bovine serum albumin (BSA) by means of carbodiimide. The absence of the pyroglutamyl group resulting in a free and potentially reactive aminoacid was used to allow conjugation of BSA to the N-terminal of SHG 2-17. The complex SHG 2-17/BSA in Freund's adjuvant was given by footpad injection. The produced antiserum was sensitive enough to measure gastrin levels below $100 \mathrm{pg} / \mathrm{ml}$ and did demonstrate minimal cross reactivity with CCK and caerulein, which shares the $\mathrm{C}$-terminal tetrapeptide with gastrin (31). In the second technique, reported by Yalow and Berson (32), immunogenicity of gastrin is improved by the uise of a crude preparation. They used crude porcine gastrin-1 to raise antibodies in guinea pigs and highly purified porcine G-17-1 to label with 125 . Their sensitive and specific radioimmunoassay had a $90 \%$ cross reactivity with $\mathrm{SHG}$, what made this assay less specific than McGuigan's. Another disadvantage is its inconsistency in raising antibodies $(33,34)$ in contrast to the SHG 2-17/BSA complex.

It is often stated that production of good antisera for radioimmunoassay depends on fortune, green fingers etc..

However, favourable results with the SHG 2-17/BSA antigen have been found by us (35) and other investigators (36-40) and with the use of this antigen given with Freund's adjuvant in intervals of 2-3 months, this seems a certain procedure for getting a gastrin antiserum.

The timing of subsequent immunizations is best judged by following antibody titers. When titers in an animal decline, reimmunization is suggested. However, it should be noted that each animal produces antiserum of different potency and specificity, which makes the comparison of values from different laboratories difficult.

Another problem is that, as we know now, gastrin is present in blood in different molecular forms, G-13, G-17, G-34 and sometimes BBG (15-17), and although the different forms seem to show no immunochemical differences with SHG-17, it is not known which forms of gastrin are measured with one"s antiserum. Now that Prof. Wünsch (personal communication) has succeeded in synthetizing G-34, a specific antiserum against SHG-34 can be raised.

The antiserum used in our laboratory is obtained similar to the method described by McGuigan (30):

Five mg of synthetic human gastrin residues 2-17 (SHG 2-17, Imperial Chemical Industries, dissolved in 2,4 dimethylformamide are added to approximately $2.2 \times 10^{6} \mathrm{cpm}$ of previously labeled $11252-17 \mathrm{SHG}$, and mixed with $10 \mathrm{mg}$ bovine serum albumin in $0.33 \mathrm{ml} 0.5 \mathrm{M} \mathrm{pH} 7.4$ potassium phosphate buffer. 1 Ethyl-3-(3-dimethylaminopropyl)-carbodiimide, $42 \mathrm{mg}$, is added and the reaction allowed to proceed for 20 hours at $20^{\circ} \mathrm{C}$ (room temperature). After 
dialysis for 24 hours, approximately 9.3 moles of $2-17$ SHG are coupled per mole of bovine serum albumin. This preparation is injected with an equal volume of Freund's adjuwant into the toe pads of four rabbits.

Freund's adjuvant is a $4: 1$ mineral oil Arlacel-A emulsion containing killed Mycobacterium butyricum (10 $\mathrm{mg} / 100 \mathrm{ml})$ which enhances antibody formation (41).

A booster injection of the same antigen material was given in the same manner 6 months later (due to not enough SHG), and the rabbits bled after a further 7 days via the central ear artery. All four rabbits produced antibodies with two of them being of a very high titer. The serum of one of the four rabbits is used as antibody in a final dilution of $1: 150,000$. The antibody is stored in small aliquots at $-70^{\circ} \mathrm{C}$.

\section{Labeling of gastrin}

Either ${ }^{125}$ or ${ }^{131} /$ is generally used to label peptide hormones, because they are readily available in pure form, react effectively with tyrosine residues, can be counted in a gamma counter with excellent efficiency and have appropriate half lives and energies of emission. Radio-iodination in most and in our laboratory is accomplished by a modification of the technique "originally introduced by Hunter, Greenwood and Glover in 1962 (42) in which $1 \mathrm{ug} \mathrm{SHG}$ $1-17$ is added with $100 \mathrm{Ll} \mathrm{pH} 7,0.5 \mathrm{M}$ phosphate buffer to $2 \mathrm{mCl}$ carrier free ${ }^{125}$ (Cambridge Nuclear Corporation) in $8 \mathrm{ulNaOH}$. Chloramine-T is used as oxidizing agent and the reaction is allowed to proceed for 60 seconds. Sodium bisulfite $(2.5 \mathrm{mg} / \mathrm{ml})$ in $\mathrm{pH} 7.40 .5 \mathrm{M}$ phosphate buffer is used for reduction of excess chloramine. The resultant product is then applied at $4^{\circ} \mathrm{C}$. to a G-10 sephadex column of $12 \mathrm{ml}$ capacity with a drip rate of approximately $1 / 20$ seconds. The labeled peptide appears in the void volume Estimated specific activity is $250 \mathrm{mCi} / \mathrm{mm}$.

However, in spite of the simplicity of the technique, difficulties are often experienced, as expressed by one inventor of the method after 10 years in the field: "You can have a go to the technique as published in the certain knowledge that it works more often than not" ". (43)

\section{Assay-technique}

The assay is carried out in our laboratory in a total volume of $500 u$ using $10 \times 75 \mathrm{~mm}$ disposable glass tubes. The incubation components are $50 \mathrm{ul}$ of the plasma sample to be assayed (i.e., the unknown plasma sample or the standard-curve plasma sample), 250 ul $0.02 \mathrm{M}$ Barbital buffer $\mathrm{pH} 8.2,2000 \mathrm{cpm}$ $1251 \mathrm{SHG} 1-17$ in 100 ul Barbital buffer and 100 ull $1: 30,000$ rabbit antigastrin antibody making a final antibody dilution of $1: 150,000$. The mixture is incubated for 4 days at $4^{\circ} \mathrm{C}$. While Yalow and Berson (32) also use an incubation period of 4 days, McGuigan (28) incubates 48 hours and Hansky (36) only 24 hours. Stadil and Rehfell (44) comparing an incubation time of 24,48 , 72 and 96 hours at $5^{\circ} \mathrm{C}$, found no difference in binding of $1251 \mathrm{SHG}-17-1$ to gastrin antiserum after 48 hours of incubation. However, after 24 hours of incubation, a less steep dose response curve was obtained.

In similar experiments in our laboratory (unpublished data) most efficient 
binding occurred after 96 hours.

At the end of the incubation period, separation is achieved by adding 200 ul dextran - 40 (Pharmacia) coated charcoal, and allowing equilibration for 15 minutes on ice. The charcoal is a $5 \mathrm{gm} \%$ charcoal, $0.5 \mathrm{gm} \%$ dextran-40 in Barbital buffer pH 8.2, preparation.

The bound and free samples are then separated by centrifuging at 3000 rpm for 20 minutes in the cold. Both bound and free samples are counted in the gamma counter.

Determinations are carried out in triplicate, with triplicate "damage" tubes. The "damage" represents the so-called non-specific binding of $125 \mathrm{SHG} 17-\mathrm{I}$ with non-specific plasma constituents. The damage tubes contain the same incubation components, except for antibody, for which $100 \mathrm{ul}$ of Barbital buffer $0.2 \mathrm{M} \mathrm{pH} 8.2$ is substituted.

Standard curves are obtained by adding increasing known amounts of SHG $1-17(15-1000 \mathrm{pg} / \mathrm{mal})$ to human plasma, which has been rendered gastrin-free by washing with dextran coated charcoal.

The standard curve is then plotted as a function of the B/F ratio to the $\log ^{10}$ of the standard gastrin concentrations (figure 2). Such a plot describes a sigmoid curve, which approximates a straight line in the middle portion. Values for each unknown sample are read visually from the standard curve.

The concentrations of gastrin are expressed as picograms per milliliter to facilitate comparison with others and previous work. Levels above $1000 \mathrm{pg} / \mathrm{mll}$ can be measured after dilution of the plasma sample with degastrinized plasma. The slope of the standard curve reflects the sensitivity of the assay, the sharper the slope, the greater the potential sensitivity. The middle part of the curve

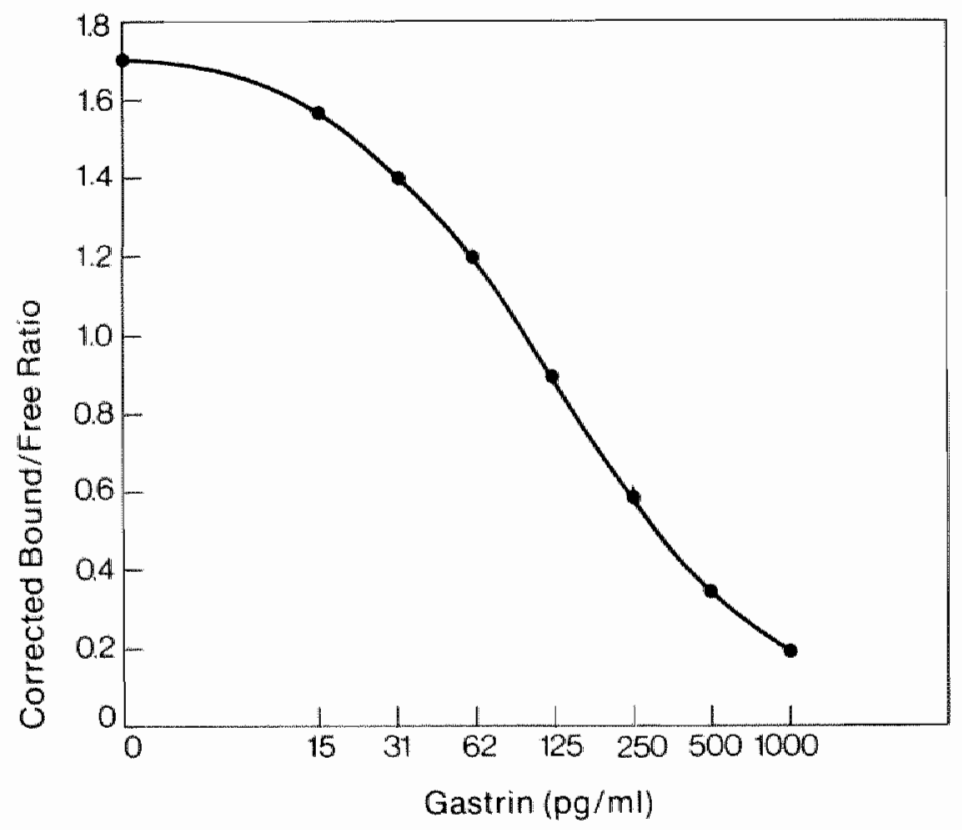

Figure 2. The gastirin radio-immunoassay standard curve SHG 1-17 is shown after dilution with known degastrinized human plasma. Values for the unknown are read from the curve. 
$(40-640 \mathrm{pg} / \mathrm{ml}$ ) represents the most sensitive part of the immunoassay for clinical purposes. The curve can be shifted to right or left by varying the incubation components.

The coefficient of variation for the assay using this technique is $5 \pm 1.3 \%$. By this assay, gastrin can be accurately measured from $16-1000 \mathrm{pg} / \mathrm{mll}$.

\section{Separation of bound and free antigen}

Since at the low concentrations of hormones usually assayed, the complexes do not spontaneously precipitate, it is necessary to find some means of separating the antibody-bound $(B)$ and free radiaactive $(F)$ hormone.

A variety of methods is available for separation of bound from free radioactive gastrin:

1. High voltage paper electrophoresis was first employed by Berson and Yalow (22) for the separation of bound and free labeled insulin. The separation uses a low ionic strength buffer ( $25 \mathrm{~V}$ per $\mathrm{cm}, 0.02 \mathrm{M}$ Veronal buffer $\mathrm{pH} 8.4,2$ to 3 hours, $4^{\circ} \mathrm{C}$ ) in which free labeled gastrin (added to plasma) does not absorb to Whatman 3 MM paper, but migrates immediately in front of serum al bumin whereas antibody-bound gastrin migrates only slightly from the site of application.

2. Chromato-electrophoresis (32), where free labeled gastrin absorbs to Whatman WB-2 resin paper at the site of application and antibody-bound gastrin migrates with the serum proteins. An advantage of this technique is that it can distinguish free-radioiodine from bound and free-labeled gastrin.

3. Absorption to anion-exchange-resins of free-labeled gastrin is the method routinely used by Yalow \& Berson $(32,45)$ and Stadil and Rehfeld (44). The resin. $20 \mathrm{mg}$ of Rohm and Hass Amberlite resin CG-4B 200 to 400 mesh, is suspended in $0.002 \mathrm{M}$ Veronal buffer to a concentration of $100 \mathrm{mg} / \mathrm{ml} ; 0.2 \mathrm{ml}$ is added to each incubation mixture. Absorption of free-labeled gastrin to resin takes placie almost immediately, but antibody-bound is excluded.

Following centrifugation at $3000 \mathrm{rpm}$ for 15 minutes, the supernatant contains the antibody-bound hormone and the resin contains the free hormone.

4. Sephadex G-75 filtration (32) in which the antibody-bound gastrin appears with the void volume and the free gastrin is retarded. However, the method lends itself only to handling of a relatively small number of samples and is: therefore, not very useful in routine radioimmunoassay (46).

5. Precipitation of the antibody-bound gastrin with poly-ethylene glycol is reported only by Stadil and Rehfeld (44). After centrifugation, the supernatant contains the free hormone.

6. The double antibody method advocated by McGuigan (30), in which a second antibody directed against rabbit antigastrin antibodies, i.e. goat antirabbit gamma-globulin, is added to the incubation mixture to precipitate the antibodybound radioactive complex. The goats are injected four times at 2 to 3 months intervals with $50 \mathrm{mg}$ of rabbit gamma globulin in complete Freund's adjuvant. Two weeks after the second and each subsequent immunization. 150 to $300 \mathrm{ml}$ of blood is obtained by jugular venapuncture. After a $35 \%$ ammonium-sulphate fractionation is prepared, the precipitated fraction is dissolved in $0.15 \mathrm{M} \mathrm{NaCl}$ $0.01 \mathrm{M}$ potassium phosphate $\mathrm{pH} 7.4 \mathrm{in}$ a volume which is equal to one-half of the original serum volume. The solution is extensively dialyzed at $4^{\circ} \mathrm{C}$ against the same saline-phosphate buffer to remove the ammonium sulphate. The amount of 
dilution of goat-antirabbit-globulin is determined by quantitative immunoprecipitation analysis. The goat-antirabbit-gamma-globulin is added to each tube after 24 hours in four fold antibody excess. After further incubation for 24 hours at $4^{\circ} \mathrm{C}_{\text {u }}$ the tubes are centrifuged at 500 rpm for 20 minutes.

Ganguli and Hunter (47) reported a double antibody method, using nonimmune rabbit serum as carrier and a commercial antirabbit gamma globulin serum by Wellcome Reagents, England. The latter was directly added to the incubation mixture for an incubation period of 24 hours at $4^{\circ} \mathrm{C}$. An advantage of the double antibody technique is that it is universally applicable, since the separation is independent of the nature of the hormonal antigen. Among its disadvantages are the running of suitable controls to account for damage of labeled homone during the incubation period for the first reaction and non-specific inhibition of the second antibody reaction (45).

7. Ethanol-precipitation method of Heding as reported by Jeffcoate in his study of the specificity of gastrin antisera (26).

8. Charcoall has been extensively used as a substance to separate "bound from free" "labeled hormone. This very simple and reliable method, originally proposed for the Vitamin-B12 assay by Miller (48), depends on the relatively complete absorption of the free-labeled hormone with little or no absorption of the bound hormone. Herbert, et al $(49,50)$, who first described the use of charcoal in radioimmunoassays, made use of dextran with a molecullar weight somewhat between that of the antigen and antibody, added in excess to prevent the antigen-antibody complex from being absorbed. They claimed that dextran acted as a molecular sieve, excluding the complex while permitting the free hormone absorption. However, if the radioimmunoassay mixture is sufficiently rich in protein, the use of dextran thas been found unnecessary, since the protein will coat the charcoal as effectively $(5 \pi-53)$. Only at a very low protein concentration did dextran improve the quality of the separation (53).

In our own studies dextran-40-coated charcoal (unpublished data) proved to be a little more efficient than uncoated charcoal and the resin method, in separating bound and free.

Criteria for suitability of a separation-method should be completeness of separation, reproducibility and simplicity. It should allow for simultaneous handling of as many as hundreds of separation. From the three most used methods, being the chromato-electrophoresis $(32,44)$, double-antibody precipitation $(25,47,54)$ and charcoal absorption $(35,41)$, the charcoal separation is the simplest method.

\section{Specificity of assay}

In general, the specificity of the radioimmunoassay is dictated by two factors:

1. Antibody specificity

2. Nature and homogeneity of the labeled gastrin.

Other factors which may intrude upon this specificity are:

3. Effect of environment, including temperature.

4. Incubation damage (plasma). 


\section{Antibody specificity}

The antibody specificity is the ability of antibodies directed against the antigen to distinguish the antigen from all other proteins. Important are the species specificity and cross reactivity with other hormones. In this respect, the $\mathrm{C}$-terminal tetrapeptide amide of gastrin is the most important part of the gastrin molecule. It represents not only all the physiological properties of gastrin, but is also the major antigenic portion. Furthermore, it was found that this particular tetrapeptide of gastrin was common to gastrin molecules from all species in which the primary structure of gastrin had been identified (55).

Mutt and Jorpes (56), however, demonstrated that the C-terminal tetrapeptide of gastrin was identical to that of a corresponding portion of CCK and the less important caerulein. Antibodies produced after immunization with this C-terminal tetrapeptide coupled to bovine-y-globulin did bind intact gastrin molecules, but was, as expected, not species-specific and showed a $100 \%$ cross reactivity with CCK.

Antibodies obtained after immunization with the more potent SHG 2-17 conjugated to bovine serum allbumin (BSA) showed a greater sensitivity, very little cross reactivity with CCK and pentagastrin, but were not species-specific.

Jeffcoate, using the same immunization technique reported no displacement of labeled gastrin by $10^{5} \mathrm{ng} / \mathrm{ml}$ pentagastrin and $10^{3} \mathrm{ng} / \mathrm{ml} \mathrm{CCK}$ (25).

Interesting was the finding of McGuigan (29), that these antibodies showed only a very slight binding with labeled SHG 1-13, and that SHG 1-13 did not inhibit the binding of labeled SHG 2-17 with these antibodies. So there was only very little antibody specificity for the peptide SHG 1-13. A possible explanation is that the $\mathrm{C}$-terminal tetrapeptide residues represent an exposed position on the surface of the gastrin molecule (28). Coupling SHG 1-13 to bovine serum albumin, McGuigan (57) succeeded in producing very specific antibodies which demonstrated a high degree of binding of SHG $1-17$ and SHG $1-13$, and no cross reactivity with $C C K$ or the $C$-terminal gastrin tetrapeptide.

The antiserum used by Yalow and Berson obtained after immunization of guinea pig with a very potent, but crude porcine gastric preparation is somewhat species-specific, binding better to porcine than human-like

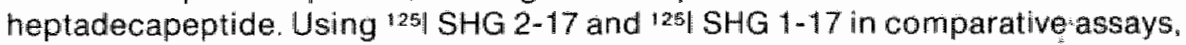
they found that 125 SHG 2-17 bound much less well than ${ }^{125}$ SHG 1-17. The antiserum showed no significant cross reactivity with $\mathrm{C}$-terminal tetrapeptide. SHG 1-13, pentagastrin or $C C_{K}$, although CCK cross reacted to a greater extent than pentagastrin, whereas McGuigan's rabbit antiserum exhibited the same reactivity for pentagastrin and CCK.

By using a crude porcine gastrin preparation for immunization, the antiserum will contain antibodies to contaminate as well as to gastrin. But as long as the labeled gastrin is highly purified (porcine gastrin), this will not interfere with the specificity of the antigen-antibody reaction (32).

Although the cross reactivity of CCK with gastrin antibodies in the antiserum used by most laboratories $(28,32,35,36,44,47,54)$ is too low to interfere with plasma gastrin measurement it might conceivably interfere in assays of tissue extracts containing high $\mathrm{CCK}$ and low gastrin concentrations. 
should be the same as for endogenous plasma gastrin. However, immunoreactive gastrin consists of components with different molecular sizes $\{9,14,58$, 59). With most antisera, it seems that G-13, G-17 and G-34 are immunochemically identical (16). The exact immunoreactive components of gastrin measured by one's assay are not precisely known. Specific antisera raised against the synthetic different molecular forms of gastrin will give us an answer about the physiological and possibly clinical significance of these different forms in the near future.

\section{Nature of Gastrin used for labeling}

As emphasized previously, the gastrin used forlabeling should be as pure as possible and the labeled gastrin should have a high specific activity. Most laboratories use SHG 1-17 (Imperial Chemical Industries) as a standard for labeling, but occasionally the SHG 1-17 is impure or at least is not recognized by antibodies previously raised to gastrin.

When new gastrin has been obtained, the identity of the SHG 1-17 should be checked against the antibody so that other peptides, which occasionally are received with or in place of SHG 1-17 are not labeled. Yalow and Berson (32) once reported a six-fold difference between two preparations of SHGI, the stronger being only $23 \%$ as potent immunochemically as Gregory PG I, while the other SHG I had 80\% immunochemically potency of Gregory PG I (60). These investigators suggest that as a stable standard is not yet available, SHG I should be referred with the very stable native PG-I (61), which is available from the Medical Research Council of England.

The labeling of gastrin is the most troublesome and variable aspect of the gastrin radioimmunoassay. Although ${ }^{125}$ has a lower specific activity than ${ }^{131}$ ( $18 \mathrm{mCl} / \mathrm{ug}$ compared with $125 \mathrm{mCi} / \mathrm{ug}$ ) most laboratories use 125 for labeling of gastrin because ${ }^{125}$ / has a higher counting efficiency and a longer half-life (60 days) (62). ${ }^{125}$ SHG 1-17 deteriorates, even in frozen state, and new labeled gastrin should be made every 2-3 weeks, as falsely high gastrin values result if this is not done. The ${ }^{125}$ can also be of poor quality, the SHG $1-17$ impure or the purification of labeled gastrin inefficient, all of which tend to make the label poor.

The radio-iodination method of Hunter and Greenwood (42) using chloramine-T as an oxidizing agent is at present the preferred and most widely used technique.

The labeling takes place in a small volume with carrier free ${ }^{125}(2 \mathrm{mC})$ and small quantities of gastrin $(1 \mathrm{ug})$. In a few seconds, $85-90 \%$ of iodine is bound to gastrin and after 60 seconds, the reaction is stopped with sodium metabisulfate and the unchanged 125 is separated by gel-filtration.

\section{Effect of environment}

The incubation conditions of the standards and unknowns should be identical for any factor that might affect the immunochemical reaction.

Like all antigen-antibody reactions, the gastrin immunoassay is sensitive to $\mathrm{pH}$ differences, although small changes in $\mathrm{pH}$ are relatively well-tolerated.

The optimum pH is thought to be between 8 and 9 (44).

In our own studies (unpublished data), the optimum pH was $8.2-8.4$.

Investigating the non-specific interference of sodium chloride, albumin, 
glucose, urea and serum protein it was found that the gastrin immunoassay was remarkably stable $(44,63)$. Only sodium chloride in a concentration of greater than $17 \mathrm{mM}$ per incubation mixture interfered. Albumin in a range of 0 to $64 \times 10^{13} \mathrm{mM}$, glucose 0 to $4.4 \mathrm{mM}$, urea up to $13.3 \mathrm{mM}$ and serum protein up to 500 uM did not change the standard curve. In fact, inclusion of protein is required to prohibit non-specific and variable absorption of labeled and unlabeled gastrin to glass.

Heparinized plasma (heparin 100 USP units/ml) has no effect on the immunoassay of gastrin (64). When using the double antibody technique, EDTA is required for incubation (64). Although gastrin itself is heat restistant, the assay is exquisitely temperature sensitive, as more antigen is bound at $4^{\circ} \mathrm{C}$ than at $10^{\circ}$ or $30^{\circ} \mathrm{C}(44)$. A packed refrigerator in which poor circulation allows the temperature to rise from 4 to $10^{\circ}$ will almost certainly produce poor results with the assay. The heat stability of gastrin can be used in boiling the plasma for $5-10$ minutes to precipitate contaminating proteins, often the cause of a high "damage"."

\section{Incubation Damage}

Certain substances in plasma may denature, destroy or alter gastrin and labeled gastrin so that it becomes unreactive with antiserum or otherwise unavailable to antiserum. These altered products may bind to normal serum proteins. This non-specific binding or incubation damage average a $5-10 \%$ $(53,60,63)$ and can be reduced with boiling. Occasionally a damage as great as $50 \%$ is observed in plasma of patients with renal failure (65). Thus, although boiling of plasma is not recommended routinely, it may be helpful for an occasional sample that shows extensive incubation "damage".

\section{Sensitivity and Precision of Assay}

The sensitivity of an immunoassay, being defined as the smallest quantity or concentration of substance that can be detected reliably by the assay (66), is (largely) dependent on the energy of the antigen-antibody reaction (45) and is reflected in the slope of the standard dose response curve. The sharper the slope, the greater the potentiall sensitivity of the assay.

In their kinetic studies, Berson and Yalow (45) showed that the change in $B / F$ with change in hormone concentration is greatest when the hormone concentration is small compared to the antibody concentration and further that the arntiserum should be used in a dilution that will bind about $50 \%$ of the smallest adequate quantity of llabeled hormone in the absence of unlabeled hormone, in order to increase the sensitivity.

At the moment, the sensitivity of most assays varies between 5 to $25 \mathrm{pg} / \mathrm{ml} / 30$, $32,35,36,44,47,54$ ) and is sufficient to measure physiologic fasting gastrin levels, which are seldom less than $20-30 \mathrm{pg} / \mathrm{ml}$.

Precilision of the assay, defined as the variation in estimation of the hormone can be expressed as the coefficient of variation, of multiple gastrin determinations in the same serum samples and varies between 5 and $10 \%$ for the different laboratories $(32,35,36,47)$. For optimal precision, samples containing high gastrin concentrations should be diluted so that they produce inhibition in the 
most precise portion on the curve. Besides this intra-assay precision, interassay precision can be evaluated by replicate measurements of different sera over a certain period.

\section{References}

\section{Edkins, J.S.}

On the Chemical Mechanism of Gastric Secretion.

Proc.Roy.Soc.Biol. 76:376, 1905.

\section{Komarov, S.A.}

\section{Gastrin.}

Proc.Roy.Soc.Exp.Biol.Med. 38:514,1938.

\section{Uvnäs, $B$.}

The Part Played by the Pyloric Region in the Cephalic Phase of Gastric Secretion.

Acta Phys.Scand Suppl. 4,13:1,1942.

\section{Gregory, R.A. and Tracy, H.S.}

The Constitution and Properties of Two Gastrins Extracted from Hog Antral Mucosa I. The Isolation of Two Gastrins from Hog Antral Mucosa II. The properties of Two Gastrins Isolated from Hog Antral Mucosa.

Gut 5:103,1964

5 Gregory H., Hardy P.M., Jones D.S., Kenner G.W. and Sheppard R.C.

The Antral Hormone Gastrin I: Structure of Gastrin.

Nature (London) 204:931,1964.

6 Anderson J.C., Barton M.A., Gregory R.A., Hardy P.M., Kenner G.W., MacLead J.K., Preston J., Sheppard R.A. and Marley J.S.

The Antral Hormone Gastrin II. Synthesis of Gastrin.

Nature (London) 204:433, 1964

7 Bentley P.H., Kenner G.W., Sheppard R.C.

Structure of human gastrin I and II.

Nature 209:583,1966.

8 Kenner G.W., Sheppard R.C.

Gastrins of various species.

Frontiers in Gastrointestinal Hormone Research Ed. Andersson published by

Almqvist and Wiksell, Stockholm, 1973.

9 Gastrin Heterogeneity.

Editorial in British Medical Journal 112,1975

10 McGuigan J.E.

Immunologic Studies of Gastrin.

New Engl.J.Med. 283:137,1970.

11 Temperley J.M., Stagg B.H. and Wyllie J.H.

Disappearance of Gastrin and Pentagastrin in the Portal Circulation.

Gut $12: 372,1971$

12 Yalow R.S. and Berson S.A.

Size and Change Distinctions between Endogenous and Human Plasma Gastrin in Peripherall Blood and Heptadecapeptide Gastrins.

Gastroenterology 58:609,1970.

13 Gregory R.A. and Tracy H.J.

Isolation of Two "Big Gastrins" from Zollinger-Ellison Tumor Tissue.

The Lancet II:297, 1972 .

14 Gregory R.A. and Tracy H.J.

The Chemistry of gastrins: Some recent advances. 
In International Symposium on Gastrointestinal Hormones.

Ed. J.C. Thompson, University of Texas Press, pp. $13,1975$.

15 Yalow R.S. and Berson S.A.

And now "Big, Big" Gastrin.

Biochem.Biophys. Res.Commun. 148:391, 1972.

16 Yalow R.s. and Wu N:

Additional Studies on the Nature of Big, Big Gastrin.

Gastroenterology 65:19,1973.

17 Straus E. and Yalow R.S.

Studies on the distribution and degradation of heptadecapeptide, Big and

Big Big Gastrin.

Gastroenterology 66:936,1974.

18 Gregory R.A. and Tracy H.J.

Isolation of two Mini-gastrins from Zollinger-Ellison tumor tissue.

Gut 15:683,1974.

19 Rehfeld J.F.

Three components of gastrin in human serum. Gell-filtration studies on the molecular size of immuno-reactive serum gastrin.

Biochem.Biophys.Acta 285:364,1972.

20 Pearse A.G.E.

Common cytochemical and ultrastructural characteristics of cells producing polypeptide hormones (The APUD series) and their relevance to thyroid and ultimobranchial C-cells and calcitonin.

Proc.Roy.Soc.Biol. 170:71,1968.

21 Wilken B.J., Hunt D.G., Lowe C.F., Billups W.A., Turner M.D. and Hardy J.D.

Sensitivity, range ande rellability of a method for the bioassay of gastrin.

J.Clin.Res. 9:551,1969.

22 Wilson S.D., Mathison ل.A., Schulte W.J. and Ellison E.H.

The role of bioassay in diagnasis of ulcerogenic tumors.

Arch. of Surg. 97:437,1968.

23 Yalow R.S. and Berson S.A.

Assay of Plasma Insulin in Human Subjects by Immunologic Methods.

Nature (London) 184:1648,1959.

24 Gilliland P.F. and Prout T.E.

Immunologic Studies of Octapeptides II, Production and Detection of

Antibodies to Oxytocin.

Metabolism 14:918,1965.

25 McGuigan J.E.

Antibodies to the Carboxy-terminal Tetrapeptide of Gastrin.

Gastroenterology 53:697,1967.

26 Jeffcoate S.L.

Radioimmunoassay of Gastrin, Specificity of Gastrin Antisera.

Scand. J. Gastroent. 4:457,1969.

27 Boyd G.W. and Peart W.S.

The Production of High Titre Antibody Against Free Angiotension.

Lancet II:129, 1968.

28. McGuigan J.E.

Studies of the Immunochemical Specificity of Some Antibodies to Human

Gastrin.

Gastroenterology 56:429,1969.

29 Stremple J.F., Abramoff P, Van Oss C.J., Wilson S.D. and Ellison E.H.

Antibodies to Synthetic Human Gastrin 1.

Lancet II:1180,1967.

30 McGuigan J.E.

Immunochemical Studies with Synthetic Human Gastrin. 
Gastroenterology 54:1005, 1968

\section{McGuigan J.E.}

Binding of Caerulein by Antibodies to Human Gastrin I.

Gastroenterology 56:858,1969.

32 Yalow R.S. and Berson S.A.

Radioimmunoassay of Giastrin.

Gastroenterology $58: 1,1970$.

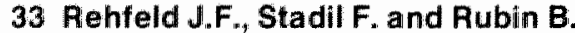

Production and Evaluation of Antibodies for the radioimmunoassay of gastrin. Scand J.Clin. Lab.Invest. 30:221, 1972.

\section{Jaffe B.M. and Walsh J.H.}

Gastrin and related peptides in "Methods of Hormone radioimmunoassay Ed. by Jaffe and Behrman: published by Academic Press, New York pp. 251, 1974.

35 Wesdorp R.ll.C. and Fischer J.E.

"Assay of Gastrin" in "Hormones in Human plasma".

Ed. H.N. Antoniades, published by Harvard Medical Press, Boston, pp.657-678, 1976.

\section{Hansky J. and Cain M.D.}

Radioimmunoassay of gastrin in Human serum.

Lancet II:1388,1969.

37 Feurle G., Ketterer $\mathbb{H}$., Becker H.D. and Creutzfeldt W.

Circadian serum gastrin concentrations in control persons and in patients with ulcer disease.

Scand.J.Gastroent. 7:177,1972.

38 Wyllie J.H., Boulos P.B., Lewin M.R., Stagg B.H. and Clarck C.G.

Plasma gastrin and acid secretion in man following stimulation by food, meat extract and insulin.

Gut 13:887,1972.

\section{Buchanan K.D.}

In "Radioimmunoassay methods". Ed. Kirkham \& Hunter, published by Churchill Livingstone, London, pp.172,1971..

\section{Stadil F.}

Gastrin and Insulin hypoglycemia.

Scand.J.Gastroent.vol.9, suppl. 23:1,1974.

\section{Freund $\mathrm{J}$.}

The Effect of Paraffin Oil and Mycobacteria on Antibody Formation and Sensitization.

Am. J.Clin.Pathol 21:645,1951.

42 Hunter W.M. and Greenwood F.C.

Preparation of lodine-131 labeled Human Growth Hormone of High Specific Activity.

Nature 194:495,1962.

\section{Greenwood F.C.}

Radio-iodination of peptide hormones: Procedures and problems. In

"Principles of competitiwe protein-binding assays". Ed. Odell \& Daughaday published by J.B. Lippincott, Philadelphia \& Toronto, pp. 288-296,1971.

44 Stadil F. and Rehfeld J.F.

Determination of Gastrin in Serum.

Scand.J.Gastroent. 8:101,1973.

45 Berson S.A. and Yalow R.S.

Immunoassay of Protein Hormones. In "The Hormones" Ed. G. Pincus, K.V. Thimann, E.B. Astwood, published by Academic Press, New York pp. $557,1964$.

\section{Yalow R.S.}

Separation Methods. In "Protein and Polypeptide Hormones", 
Ed. M. Margoulies, published by Exerpta Medica Foundation, Amsterdam.

pp. 627,1969 .

47 Ganguli P.C. and Hunter W.M.

Radioilmmunoassay of Gastrin in Human Plasma.

J. Physiol. 220,499,1972.

48 Miller O.N.

Determination of Bound Vitamin $B_{12}$.

Arch.Biochem. Biophys. 68:255,1957.

49 Herbert V., Lau K.S., Gottlieb C.W. and B\#eicher S.J.

Coated Charcoal Immunoassay of Insulin.

J.Clin. End. and Metab. 25: 1375.1965.

50 Herbert $V$.

Coated Charcoal Separation of Free-Labelled Hormone from Hormone Bound to Antibody. In "Protein and Polypeptide Hormones", Ed. M. Margoulies, published by Exerpta Medica Foundation, Amsterdam, pp. 55, 1969.

51 Ekins R.P.

In "Proteins and Polypeptide Hormones", Ed. M. Margoulies, published by Exerpta Medica Foundation, Amsterdam, pp. 633,1969.

52 Palmeiri G.M.A., Yalow R.S. and Berson S.A.

Absorbent Techniques for the Separation of Antibody-Bound from Free

Peptide Hormones in Radioimmunoassay.

Horm. Metab.Res. 3:301,1971.

53 Binoux M.A. and Odell W.D.

Use of Dextran-Coated Charcoal to Separate Antibody-Bound from Free Hormone: A critique.

J.Clin. End. and Metab. 36:303, 1973.

54 Charters A.C., Odell W.D., Davidson W.D. and Thompson J.C.

Gastrin: Immunochemical Properties and Measurement by Radioimmunoassay. Surgery $66: 104,1969$.

55 Gregory R.A.

Memorial Lecture: The llsolation and Chemistry of Gastrin.

Gastroenterology 51:953,1966.

56 Mutt V. and Jorpes J.E.

Isolation of Aspartylphenylalanine Amide from Cholecystokinin-

Pancreozymin.

Biochem. Biophys. Res. Commun. 26:392,1967.

57 McGuigan J.E.

Antibodies Specific for Gastrin Without Immunological Cross Reactivity with

Cholecystokinin-Pancreozymin.

Gastroenterology 58:975,1970.

58 Isenberg J.I., Walsh J.H. and Grossman M.D.

Zollinger-Ellison Syndrome.

Gastroenterology 140,1973.

59 Rehfeld $J_{\text {F }}$. and Stadil $F$.

Gel Filtration Studies on Immunoreactive Gastrin in Serum from

Zollinger-Ellison Patients.

Gut 14:369,1973.

60 Berson S.A. and Yalow R.S.

Radioimmunoassay in Gastroenterology.

Gastroenterology 62:1061,1972.

61 Yalow R.S. and Berson S.A.

Further Studies on the Nature of Immunoreactive gastrin in Human Plasma.

Gastroenterology 60:215,1971.

62 Freedlander A.E.

Practical and Theoretical Advantages for the Use of 1251 in Radioimmunoassay. 
In "Protein and Polypeptide Hormones" Ed. M. Margoulies published by Exerpta Medica Foundation. Amsterdam, pp. 351,1969.

63 Stadil F. and Rehfeld J.F.

Determination of gastrin in serum. An evaluation of the reliability of a radioimmunoassay.

Scand.J Gastroent. 8:101,1973.

64 McGuigan d.E. and Trudeau W.L.

Studies with Antibodies to Gastrin.

Gastroenterology 58:139,1970.

65 Dent R.I., Hirsch H., James $H_{\text {.J. }}$. and Fischer J.E.

Hypergastrinemia in Patients with Acute Renal Faillure.

Surgical Forum $\times \times 111312,1972$.

66 Ekins R.P.

Problerms of Sensitivity with Special Reference of Optimal Conditions. In "Proteins and Polypeptide Hormones" "Ed. M. Margoulies published by Exerpta Medica Foundation, Amsterdam, pp. 672,1969. 


\section{Chapter II}

\section{Physiology of gastrin}

\section{Sites of gastrin production}

The cells that contain gastrin are called G-cells and are mainly found in the pyloric glands of the antrum of the stomach (1) and the proximal duodenum (2) These cells are found to be most abundant in the mid portion of the pyloric gland and can be identified by immunohistochemical technics (3) and by their typical appearance on electron microscopy $(4,5)$. G-cells have a flask shape with a broad base and a narrow neck that extends to the mucosal surface. At the base of the cell which is often adjacent to a capillary, gastrin containing granules of moderate electron density are stored (2). The mucosal surface of the cells have microvillit that may contain receptors for stimulation and inhibition of the $\mathrm{G}$-cells by intraluminal contents (2).

As mentioned before, these G-cells are specialized endocrine cells which fit the cytochemical and ultrastructural characteristics of the APUD-cell series. In the late sixties, the APUD-concept has been developed by Pearse in London (6) and postulates that such cells differ from normal endocrine cells and originate from the embryonal neuroectoderm to migrate wery early to the developing gut. While agreement with this concept is not universal, the hypothesis is supported by cytochemical and ultrastructural findings and may be helpful in a better understanding of the mechanism of the release and interaction of the digestive hormones. In the past few years 15 different neuroendocrine APUD cells have been identified in the digestive tract, establishing the gut as a major endocrine organ.

In normal human subjects the amount of $\mathrm{G}-17$, which constitutes more than $90 \%$ of antral gastrin, is in the order of 5 to 50 ug per gram of mucosa $(7,8)$. G-34 and other molecular variants of gastrin represent less than $10 \%$ of antral gastrin content in contrast to duodenal gastrin, which consists mainly of $\mathrm{G}-34$ $(8,9)$.

In man, the concentration of gastrin in proximal duodenal mucosa is between 0.1 and 0.5 that of antral mucosa (9). Because of the greater bulk of duodenal mucosa, it is estimated that human duodenum may contain as much gastrin as human antrum (1) whereas in other species such as the dog, total duodenal gastrin is only a small percentage of antral gastrin (10).

After antrectomy and gastroduodenostomy, the increase in plasma gastrin in response to feeding is almost as great as before antrectomy in man (11), but is greatly decreased in the dog (12). The highest concentrations of intestinal gastrin are found in the proximal duodenum, with progressively lower concentrations in the remainder of the duodenum and jejunum (, 9). The gastrin extracted from human duodenum contains a higher fraction of G-34 than antral mucosa (8). The acid-secreting portion of the stomach contains less than $2 \%$ as much gastrin as the antrum, while very small amounts of gastrin have been extracted from human pancreas by some investigators, but others have found none. Similarly, by use of immunohistochemical methods some investigators have been able to identify $G$-cells in normal pancreas and others have not. Those who demonstrate gastrin 
containing cells find the hormone in delta cells (13). However the normal pancreas does not contain enough gastrin to make a substantial contribution to serum gastrin.

\section{Release of gastrin in vivo}

The physiologic stimulus for gastrin release in vivo is by food. This is achieved by three main mechanisms. First, a direct action on the G-cells by contents of the stomach bathing the microvilli on the luminal surface of the G-cells. This is considerably affected by the chemical nature of the stimulus and the only chemicals in food that are known to cause release of gastrin are calcium (14) and the digestion products of protein.

In the dog, undigested protein is ineffective, but light peptic digestion makes it as effective as complete hydrolysis to aminoacids (15), while gastrin is also released by alcohol and some animoacids (16).

In man, high protein meals, casilan (milk protein derivate) and the aminoacid glycine, the only aminoacid tested (17), are potent releasers of gastrin, whereas pure fat and carbohydrates are poor releasers. Unlike what is observed in the dog, alcohol was found to be a poor stimulant of gastrin in man (16). The second mechanism, is by mechanical distension of antrum (18) or fundus (19). This has been shown experimentally in dogs to result in the release of gastrin and thence to gastric acid secretion (20). Distension of the stomach stimulates acid secretion in man (21), but whether this action is accompanied by release of gastrin is uncertailn.

The effect of mechanical distension on gastrin release in the dog is probably mediated by local reflexes and can be blocked by atropine $(18,22)$. The importance of mechanical distension is that chemical stimulants seem to require such a background for maximal effectiveness (20).

The third mechanism is through vagal excitation which stimulates acid secretion both by releasing gastrin from the $\mathrm{G}$-cells and by direct action on the parietal cells. In the dog, vagal excitation by shamfeeding $(23,24)$ or by insulin hypoglycemia (25) causes release of gastrin that is abolished by vagotomy and blocked by atropine and therefore presumably vagal and cholinergic In man, the existence of a cholinergic mechanism for gastrin release has not yet been established, since shamteeding causes only release of gastrin in patients with duodenal ulcer (26), but this is not blocked by atropine. However, shamfeeding is not followed by gastrin release in healthy individuals (27) Species variation is clearly exemplified in the dog, where Olbe has shown that shamfeeding measured by the acid secretion from a Pavlow pouch, was enhanced by subtreshold amounts of gastrin (28) and markedly diminished by antrectomy (29). This contribution, however does not seem to be a major one in man, as the direct vagal stimulation of the oxyntic population has been shown to be the major mechanism of acid secretion in shamfeeding $(30,31)$ A still unexplained feature of vagall release of gastrin in man is that instead of being blocked by atropine as seen in the dog (32), stimulated gastrin release in response to feeding and insulin is enhanced by atropine $(33,34)$. Given a cholinergic basis for the vagal release of gastrim, this could just reflect a resistance to the atropine "block" (35). More about the role of the nervus vagus on gastrin release has been learned by observing the effect of vagotomies in their different forms on gastrin release. In man, truncal wagotomy does not abolish the release of gastrin in response to insulin (36) as it does in the dog. 
Therefore, release of gastrin by insulin in man is at least in part non-vagal and non-cholinergic. The mechanism by which insulin releases gastrin after vagotomy is not known, but the increase in circulating epinephrine may play a part since it has been shown that epinephrine can release gastrin (37, 38), an effect which is blocked by alphablockers in pheochromocytoma patients and by beta-blockers in normal individuals (39).

Gastrin release may be affected by other stimuli.

Acetylcholine is a powerful relleaser of gastrin when applied to the antral mucosa (40), as well as to the duodenall mucosa (41). Ingested calcium releases endogenous gastrin (14), while calcium is also a powerful blood born stimulus. This has been shown to correlate significantly with gastrin release in hyperparathyroidism $(42,43)$, all though it is not clear how much of a role calcium has in the release of gastrin in healthy individuals.

Locally applied anesthetic drugs inhibit stimulated gastrin release from isolated antrum in the dog (44), while they have no effect on its motility. in man and in the dog gastrin release is inhibited by the very acidity it stimulates $(45,46)$. All stimulants for gastrin release are inhibited by this negative feedback mechanism. Antrall acidification is perhaps the most powerful inhibitor of gastrin release both in the dog (47) and in man (48).

It apparently acts directly on the $\mathrm{G}$-cell because its effect persists after local anaesthetics have blocked the mucosal nerves (49). A pH of about 1.0 is needed for maximal suppression, but even at $\mathrm{pH} 2.5$ gastrim release in response to a test meal is reduced by about $80 \%$ in normal human subjects $(50)$. It is often assumed that putting acild or alkali into the fasting stomach will cause a fall or rise in plasma gastrin, but direct observations give little support to this assumption $(20,51)$. Acid inhibits the action of stimulants for gastrin release, and alkali prevents such inhibition, but acid and alkali have little or no effect on unstimulated, resting gastrin levels.

This feedback mechanism is of major clinical importance in patients whose acid secretory response is either diminished or abolished. In the gastritis that results from the presence of parietal cell antibodies (52), the lack of a physilological feedback mechanism is presumably responsible for the gradual increase of the $G$-cell population (7), an elevation of fasting plasma gastrin levels and an increased capacity to release gastrin in response to stimuli such as food (53). Their elevated fasting gastrin is composed mainly of $G-34$ and G-17 in about the same proportions as seen after feeding in normal subjects (22).

Putting acid into the stomach of hypochlorhydric patients causes a sharp decrease in their elevated serum gastrin (54),

Hormonal regulation is the second principle mechanism regulating gastrin release. The four peptides of the secretin family (secretin, glucagon, GIP and VIP) have been shown to inhibit stimulated release of gastrin (55-58).

VIP acquires an added clinical significance in that context, because of its association with the WDHA syndrome in which watery diarrhea, hypokalemia and either hypo- or achlorhydria are the major symptoms $(59,60)$. Still another hormone that inhibits gastrin release is calcitonin (61), which seems to have a regulatory function in the release, and possibly the catabolism of gastrin (62) 


\section{Release of gastrin in vitro}

In vivo studies involving gastrin release are handicapped by a series of technical problems, not the least of which is the feedback mechanism by which acid produced by the gastrin-stimulated parietal cells inhibits further antral release of gastrin. Several techniques have been derived in vivo to isolate the antrum from inhibiting mechanism. These techniques include antral exclusion and a variety of other complicated physiological techniques $(46,63,64)$. Clearly, it would be desirable to devise a physiological preparation in which reliable and reproducible release of gastrin from the gastric antrum or any other part of the small bowel could be obtainedin order to further investigate its physiology.

An isolated perfusion techniquie, used for catecholamine studlies (65) has been adapted for this purpose. The following experiments, we bellieve, suggest that an isolated perfused antrum preparation may be very useful in the elucidation of some of the physiology of gastrin. It is well documented that in vivo instillation of acetylcholine into an isolated antral pouch gives an immediate release of gastrin $(46,66)$. In these perfusion studies, acetylcholine, gllycine and calcium apparently also causes an immediate release of gastrin in vitro.

\section{METHODS}

\section{Isolated Antral Perfusion}

Sixty fasting female Sprangue-Dawley rats $(200-250 \mathrm{gm})$ were killed by cervical fracture and their gastric antra quickly removed, washed in Krebs-Ringers-A solution, everted, and placed in the perfusion chamber.

The perfusion chamber was a glass chamber $(30 \times 15 \mathrm{~mm})$ with a capacity of $2 \mathrm{ml}$, much of which was occupied by the perfused tissue. Perfusion was carried out (Figure 3) from several reservoir bottles, each of which contained an oxygenated Krebs-Ringers-A solution (67) either as a control perfusion solution, or with the releasing agent to be tested. A large series of solutions may thus be used and are connected to the perfusion chamber by a series of switching valves. From the reservoir bottles, the solutions were first allowed to flow through glass-jacketed heat exchange systems, the outer jackets of which were perfused at a constant temperatur of $40^{\circ} \mathrm{C}$ before perfusing the antral tissues. Regulation of flow rate was carried out by a four or two channell perfusion pump (Polystaltic Pump, Buchler Instruments) generally at a rate of $30 \mathrm{ml} / \mathrm{hr}(0.5 \mathrm{ml} / \mathrm{min})$. Effluent samples were collected every two minutes $(1 \mathrm{ml})$. After an initial perfusion (12 minutes) with oxygenated Krebs-Ringers-A solution to establish a basal level of gastrin efflux, the valves were turned to allow the testing substance in the same Krebs-Ringers-A solution to perfuse the isolated tissue. After a stimulatory interval of 22 minutes, the chamber was again perfused with the basal solution to re-establish the baseline level of secretion. Perfusions were carried out with $50 \mathrm{mM}$ acetylcholine $(+0.1 \mathrm{mM}$ eserine), $50 \mathrm{mM}$ glycine or with $10 \mathrm{mM}$ and $30 \mathrm{mM}$ calciumchloride added to the KrebsRingers-A solution. Control perfusions were carried out with $0.1 \mathrm{mM}$ eserine and with Krebs-Ringers-A solution without an added substance.

Each perfusion was repeated on at least six different antra. In order to test the ability of the perfused tissue to release gastrin repeatedly, we restimulated the 


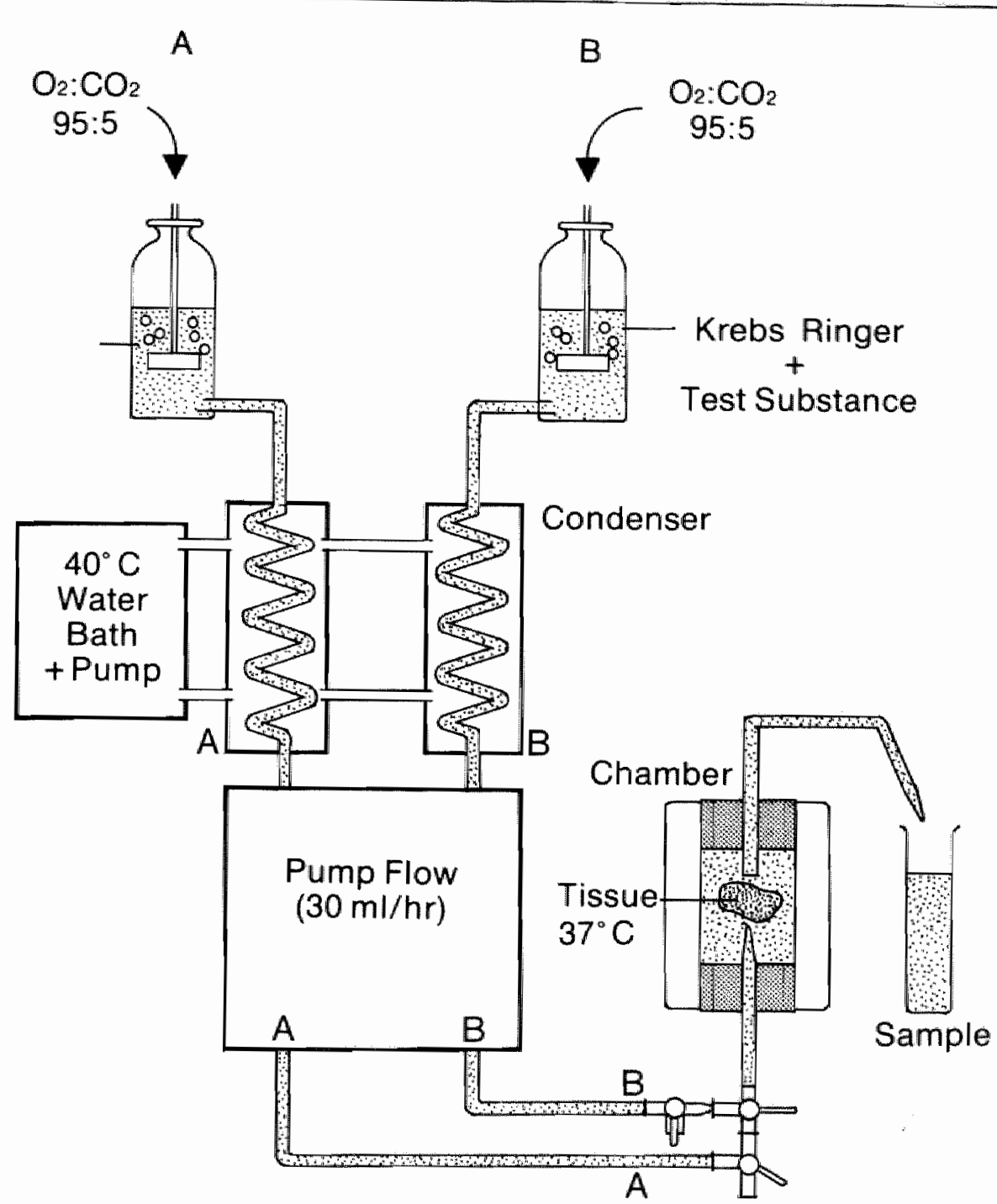

Figure 3. Experimental apparatus. From theoreservoir botlles, the Krebs-Ringers-A solution with or without test substance flows through a glass-jacketed heat exchanging system. Fegulation of the various flows into the perfusion chamber is carried out by a peristaltic pump at a rate of $30 \mathrm{ml} / \mathrm{hr}$. Samples are collected for consecu tive 2 minutes intervalls. After a suitable collection period using control solution, the valves are changed so that the test solution may be inlused. At the end of the lest period, valwes are again changed so that the control inf usion pertuses the chamber again. This anables a series of perfusions to be carried out without interirupting the fllow of perlusing solution. 
tissue after a 10 minute rest in four instances. Effluent samples were stored at $-20^{\circ} \mathrm{C}$ before assayed.

Gastrin radioimmunoassay was performed using antibodies that had been produced in rabbits after repeated immunization with synthetic human gastrin, conjugated to BSA as previously described (40). Dextran coated charcoal was used to separate labeled gastrin bound to antibody from free labeled gastrin. Each sample was assayed in triplicate on at least two separate assay determinations.

\section{Results}

Upon perfusion of unminced antirum with $50 \mathrm{mM}$ acetylcholine $(+0.1 \mathrm{mM}$ eserine), the gastrin level in the effluent increased within 2 minutes to four times the basal level and dropped rather sharply (figure 4). A smaller second peak appeared after 20 minutes $(10 \mathrm{ml})$. When switched to the Krebs-Ringers-A solution, the gastrin concentrations returned to the basal level. The large standard error can be explaimed by the variation between basall levels of different perfusions, with basal levels varying between $70-300 \mathrm{pg} / \mathrm{ml}$.

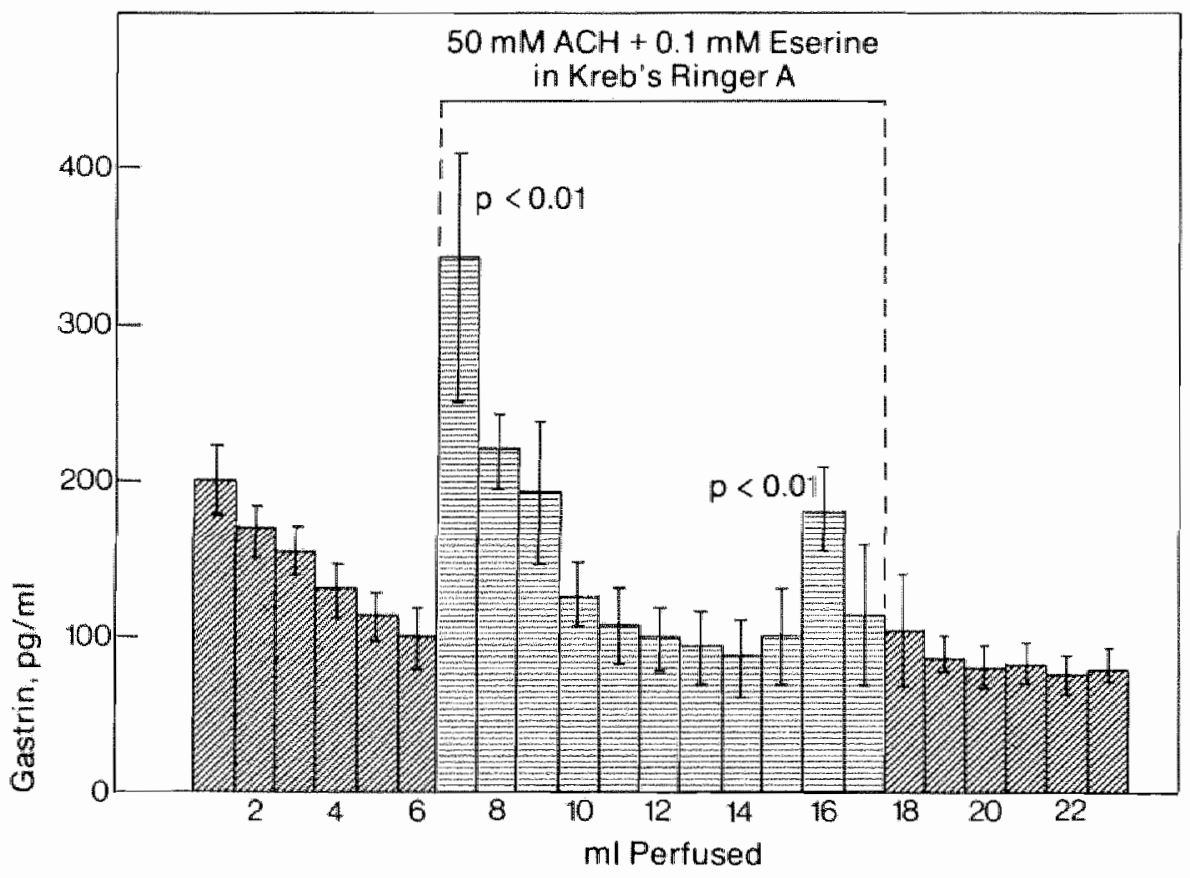

Figure Mean effuent gastrin lewels \pm S.E. A. following the infusion of $50 \mathrm{mM}$ acetylcholime \pm $0.1 \mathrm{mM}$ eserine in Krebs $\sim$ Ringers $-A$ solution. The means are the result of 9 different pertusions of unminced rat antra. After an initial 12 minutes period of perfusion with Krebs-Ringers-A solution, perfusion with a test solution is carried out tor 22 minutes after which Krobs-Aingers-A is allowed to perfuse the antrum eqgain.

Glycine, a known local stimulator of gastrin release, elicited a smaller reaction from the antral tissue. During perfusion with $50 \mathrm{mM}$ glycine, gastrin levels reached 2 times the basall level in 4 minutes after which they gradually decreased (figure 5). No second peak was seen. However, a consistent feature 


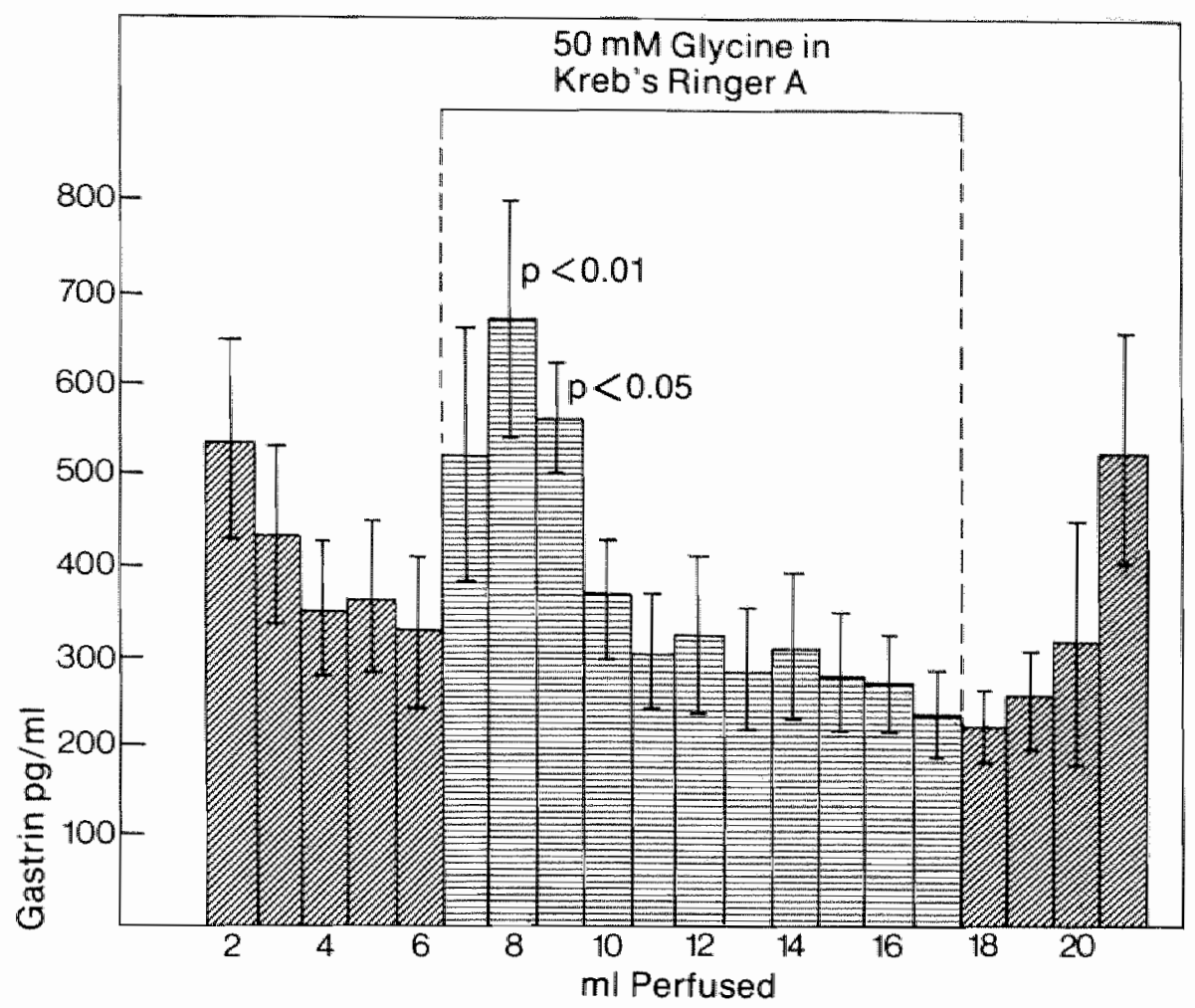

Figure 5. Mean effiuent gastrin levels ( 1 S.E.M.) following perfusion of unminced rat antrum in Krebs-Aingers-A solution with $50 \mathrm{mM}$ glycine. After an initial 12 minutes perf usion with Krebs-PingersA to establish a baseline, glycine is perfused for a 22 minutes period. Note that after the term ination of glycine perfusion and when the antra are perfused with Krebs-Ringers-A, a high sporitaneous affluent persists, as if the tissue were darnaged by glycine. Results represent mean \pm S. E M. for 6 indiwidual rat antra.

during perfusion with glycine was increased spontaneous leakage of gastrin, even after the perfusate had been changed back to Krebs-Ringers-A solution. This may, however, represent a delayed second peak, although this occured after changing back to the control solution.

Upon perfusion with $10 \mathrm{mM}$ or $30 \mathrm{mM}$ calcium-chloride-containing KrebsRingers-A solution, gastrin levels in the effluent increased within 4 minutes to twice the basal level, similar to perfusion with $50 \mathrm{mM}$ glycine (Figure 6). There was no apparent difference between the effect of high and low concentration of calcium-chloride. No secondary release of gastrin was seen.

Six control experiments with $0.1 \mathrm{mM}$ eserine alone, as well as Krebs-Ringers-A solution without an added substance, failed to increase effluent gastrin (Figure 7). In four other experiments, the ability of the tissue to release gastrin at various intervals was tested by restimulating the tissue after a 10 minute rest period after the initial release by acetylcholine. As shown in Figure 8, large amounts of gastrin are again released, confirming a stable reproducible model. 


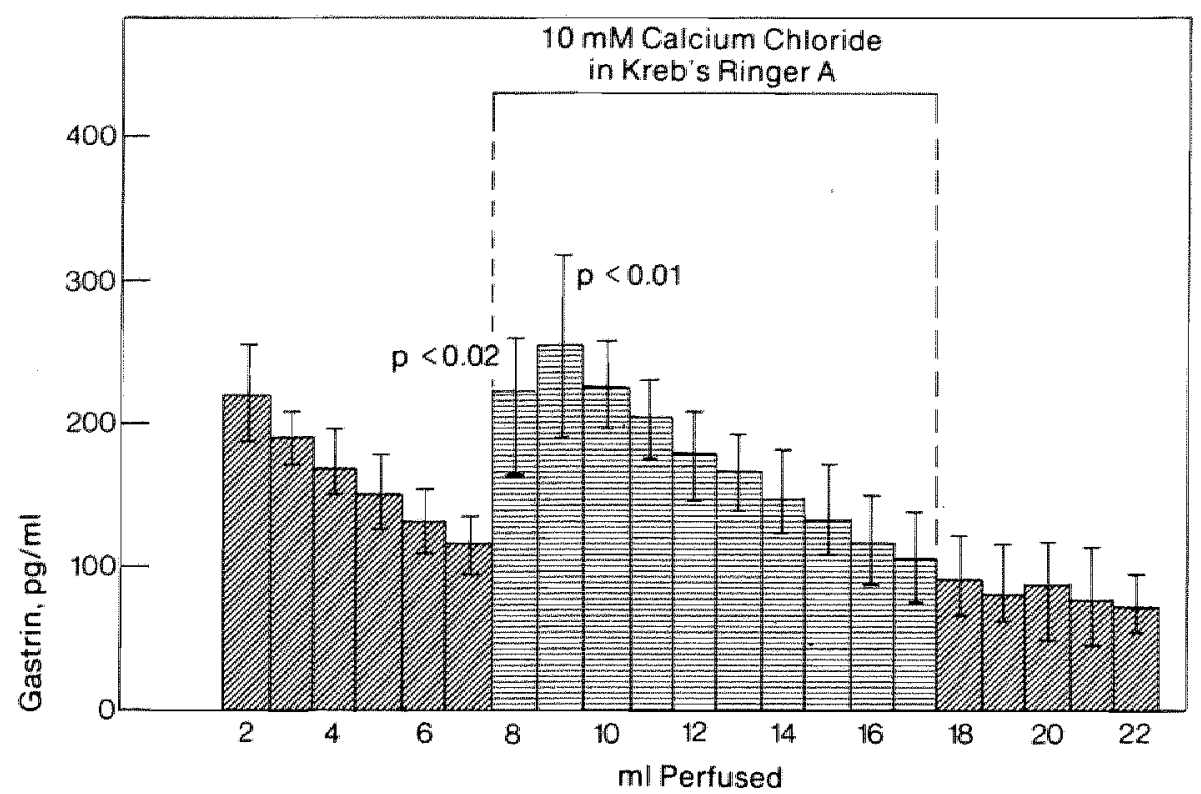

Figure 6. Mean effluent gastrin levels ( S.E.M.) following 6 perfusions of unminced gast ric antra with $10 \mathrm{~mm}$ calcium chlloride in Krebs-Ringers-A. After the initial 12 minutes perfusion to establish a baseline $10 \mathrm{mM}$ calcium is perfused for 22 minutes. Only one peak was seen.

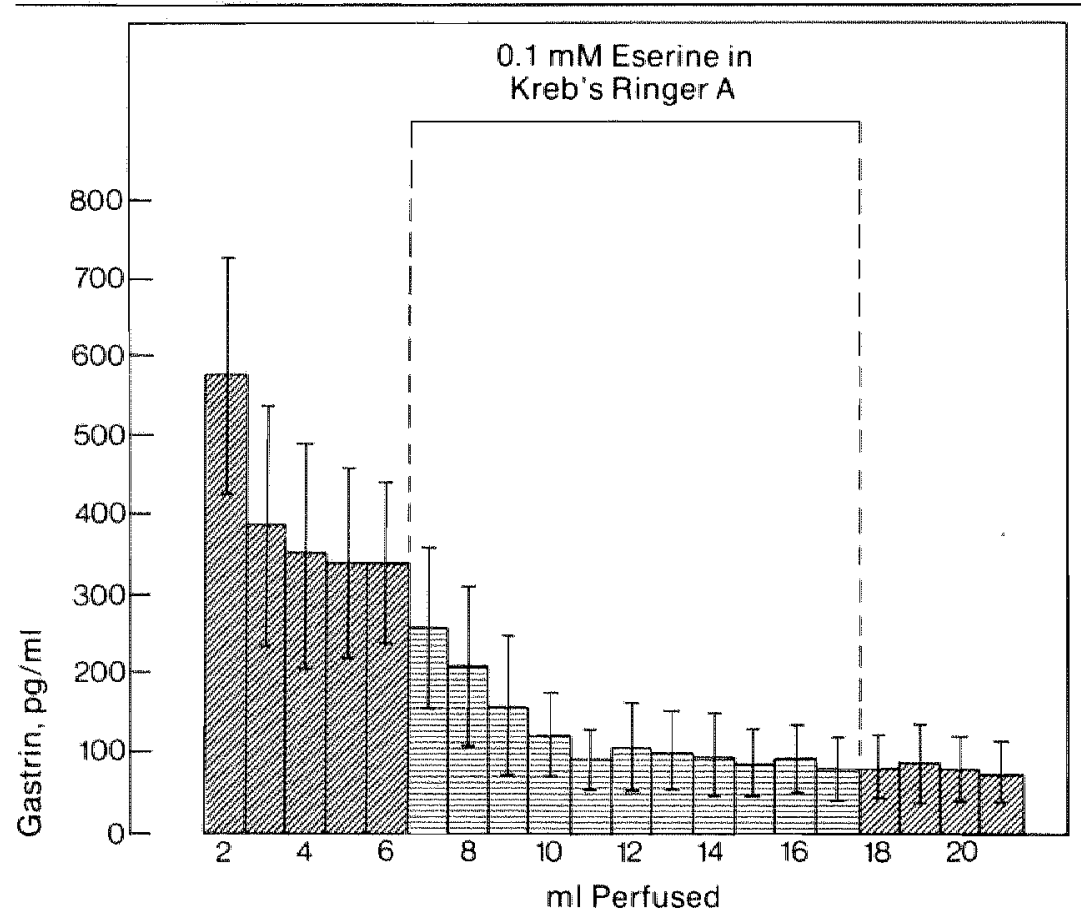

Figure 7. Mean effluent gastrin levells ( 1 S.E.M.) following 6 control perfusion of unminced rat antrum in Krebs.Finger-A solution with $0.1 \mathrm{mM}$ eserine. After an initial 12 minutes control infusion, $0.1 \mathrm{mM}$ eserine in Krebs-Ringers-A solution was allowed to perfuse 6 individual antra for 22 minutes. 


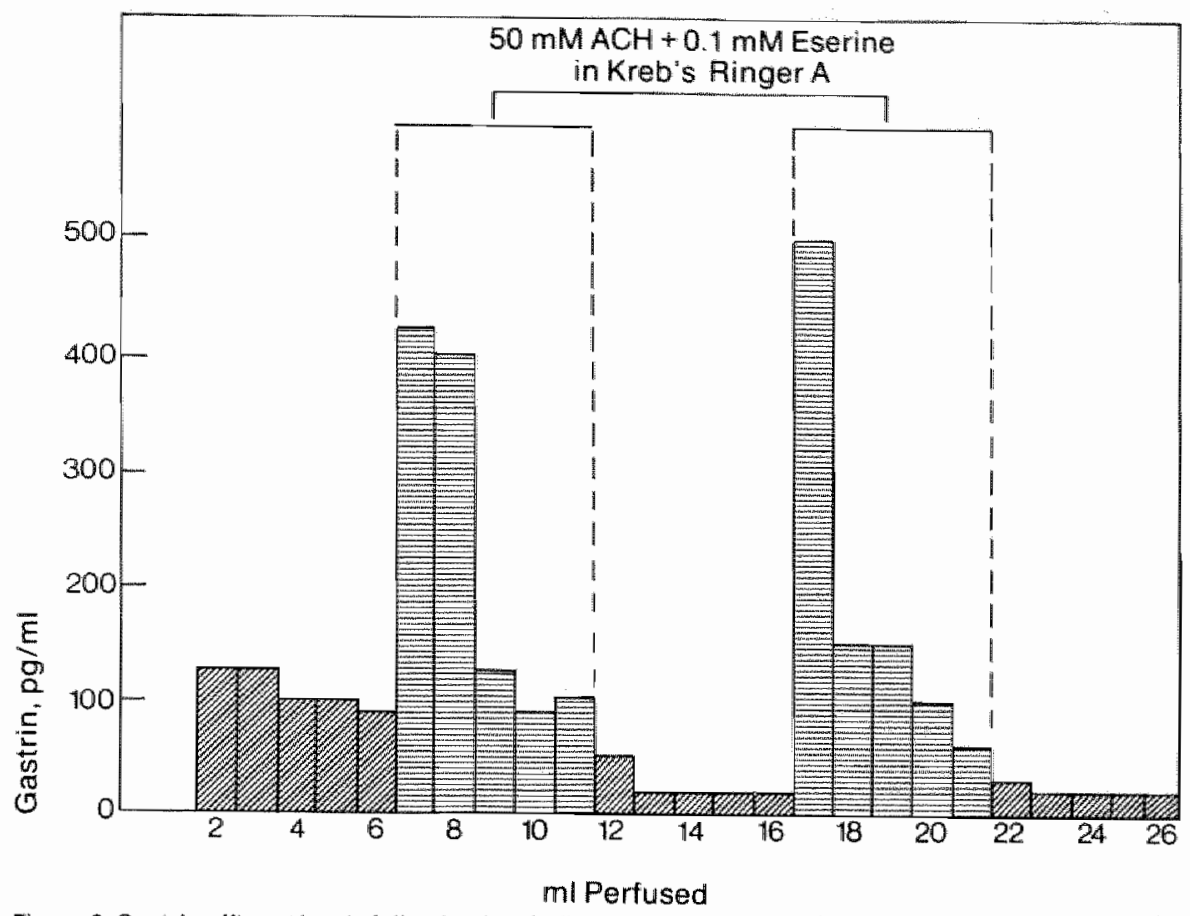

Figure 8. Gastrin effluent levels following two individual 10 minutes perfusion periods of an unminced rat antrum with $50 \mathrm{mM}$ acetylcholine $\pm 0.1 \mathrm{mM}$ eserine in Krebs-Ringers-A. Note the large second peak suggesting that repeated stimullation brings about a new release of gastrin in almost equal amounts.

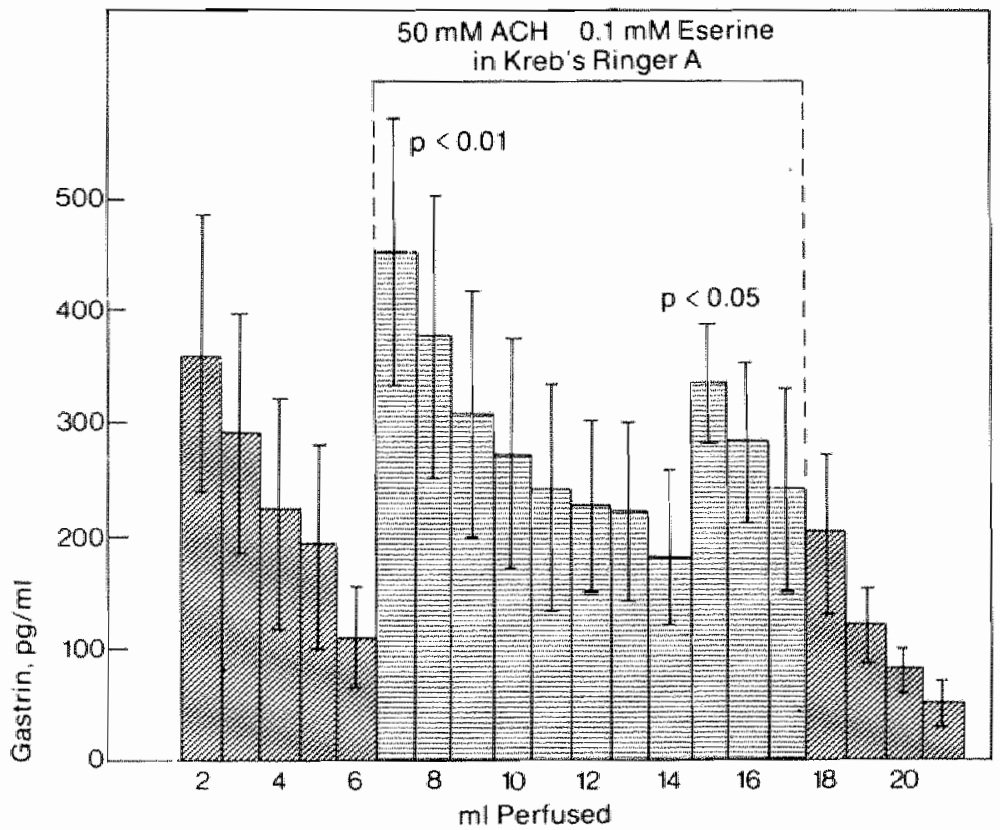

Figure 9. Mean effluent gastrin levels $( \pm$ S. E.M.) following 6 different perf usions of minced rat antra in Krebs-Ringers-A solution. 
biphasic release of gastrin. After the initial release of gastrin from the isolated perfused antrum, there was inevitable a secondary peak, smaller than the first, suggesting secondary release of gastrin. In order to better demonstrate this phenomenon, the isolated antrum was minced, allowing better contact between antral gastrin-containing cells and the perfusion fluid. However, as can be seen in Figure 9, the primary release of gastrin was the same as upon perfusion of unminced antrum, although the secondary release was greater and lasted for a longer period of time. Secondary release of gastrin was again seen only after perfusion with acetylcholine in the minced preparation.

Gastric antra were assayed after perfusion and compared with 12 gastric antra which had been perfused without stimulation for ten minutes. There was great individual variation between antra. No consistent difference between "pre and post" infusion antra was detected.

\section{Discussion}

The results of this study confirm the results of those previously reported in vivo studies in which antral gastrin release was strongly stimulated by bathing the antral mucosa with acetylcholine $(46,66)$ and to a lesser extent by local stimulation with glycine (68) and calcium solutions (14). In these experiments, the potency of acetylcholine is considerably greater than that of glycine and the two calcium-chloride containing solutions.

The apparent biphasic release of gastrin from the isolated antrum perfused with acetylcholine has been reported in one in vivo preparation (46). Other polypeptide hormones have demonstrated a secondary release with continuing stimulation, but not after a single stimulus $(69,70)$.

One can only speculate on the meaning of the secondary release of gastrin. It may well be that the two peaks elicited from the isolated perfused rat antrum represent different pools of stored gastrin, the first being more available and the second being less available, but ultimately finding its way to the surface of the cell. Alternatively, the first peak may represent stored gastrin, the secondary peak newly synthetized gastrin. In support of this concept is that perfusion with glycine and the two calcium solutions have shown only a monophasic release. The only substance which results in a biphasic release of gastrin appears to be the physiological releaser, acetylcholine, and it is not unreasonable to assume that perharps here synthesis is stimulated as well. This is in accordance with the finding of a glucose-induced biphasic release of insulin in vitro $(70)$, which is enchanced by adding acetylcholine. A similar biphasic release of insulin is obtained from isolated pancreas following vasoactive intestinal peptide infusion (71).

After antrum is minced, allowing more of the antral cells to come into contact with the perfusing solution, it is of interest that the initial peak remains the same, but secondary release is increased, suggesting that perhaps the second pool may not be on the surface, but deeper in the cells. Synthesis may take place inicells not as readily available.

That eserine failed to release gastrin suggests that cholinergic nerves are not involved in gastrin release or at least in this preparation, where such nerves, if necessary, are no longer viable.

This preparation simplifies the study of antral gastrin release, doing away with many of the inhibiting feedback mechanisms, and may be profitably applied to the study of other endocrine organs as well. 


\section{Release of duodenal gastrin}

Duodenal gastrin makes a considerable contribution to the basal circulating levels of this hormone in man. Gastrin containing G-cells have been demonstrated in the duodenum (2). The concentration of gastrin in the duodenal mucosa of man has been variously reported as being equal to (1) or less than (9) the concentration in the antral mucosa.

Cllinical studies following Billroth I and Billroth II gastrectomy with vagotomy demonstrated significantly higher basal and post-prandial plasma gastrin levels after Billroth I as compared with Billroth II gastrectomy, suggesting a major contribution of duodenal gastrin to basal and post-prandial plasma gastrin values (11). Recently, it has been shown that intraduodenal application of a testmeal in patients with duodenal ulcer and after Billroth I gastrectomy resulted in an increase of plasma gastrin and gastric acid secretion (72).

The characteristics of release of duodenal gastrin may be similar to or different from the characteristics of antral gastrin, which have been extensively

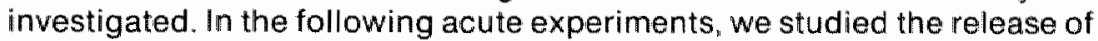
duodenal gastrin in dogs. The results demonstrate distinct differences in characteristics of duodenal gastrin release as opposed to antral gastrin release.

\section{Materials and methods}

Thirteen healthy mongrel dogs, weighing between $15-22 \mathrm{~kg}$ and previously conditioned for 2 weeks, were fasted for 18 hours. Under pentobarbital general anaesthesia, a precise mucosal antrectomy (73) was performed to exclude the contribution of antral gastrin (Figure 10). A transverse incision was made on the greater curvature of the stomach from the pylorus to beyond the antral-fundus border, which was defined circumferentially with $\mathrm{pH}$-sensitive paper. The mucosa was separated from the submucosa (figure 10 and 11), while the nerves of Latarjet were carefully preserved. A stout tie was placed around the pylorus to prevent blood from entering the duodenum. The superior mesenteric vein was cannulated with a thin, theparin filled silastic catheter for intermittent blood sampling, and the orifice placed opposite the entrance of the gastroduodenal vein (figure 12).

For perfusion-studies, two soft Foley catheters were placed in the duodenum: a small no 8 (French) with its tip in the duodenal bulb and a large no.36 (French) Foley for drainage with its tip at the ligament of Treitz to collect the efferent bile and pancreatic secretions. Dogs were allowed to equilibrate for one hour. Infusions of $5 \%$ dextrose/saline at $50 \mathrm{cc} / \mathrm{hr}$ were carried out throughout the experiment and blood pressure, arterial blood gases and urine output monitored.

Baseline samples were taken both before and after induction of anaesthesia, and in general agreed well.

Three general types of stimulation were administered: "vagal" stimulation with either insulin or 2-deoxy-D-glucose, lacal perfusion with various solutions known to release antral gastrin and distension.

Stimulation with a given stimulus was performed in randomized order on at least 6 different occasions while blood samples were taken from the gastro- 

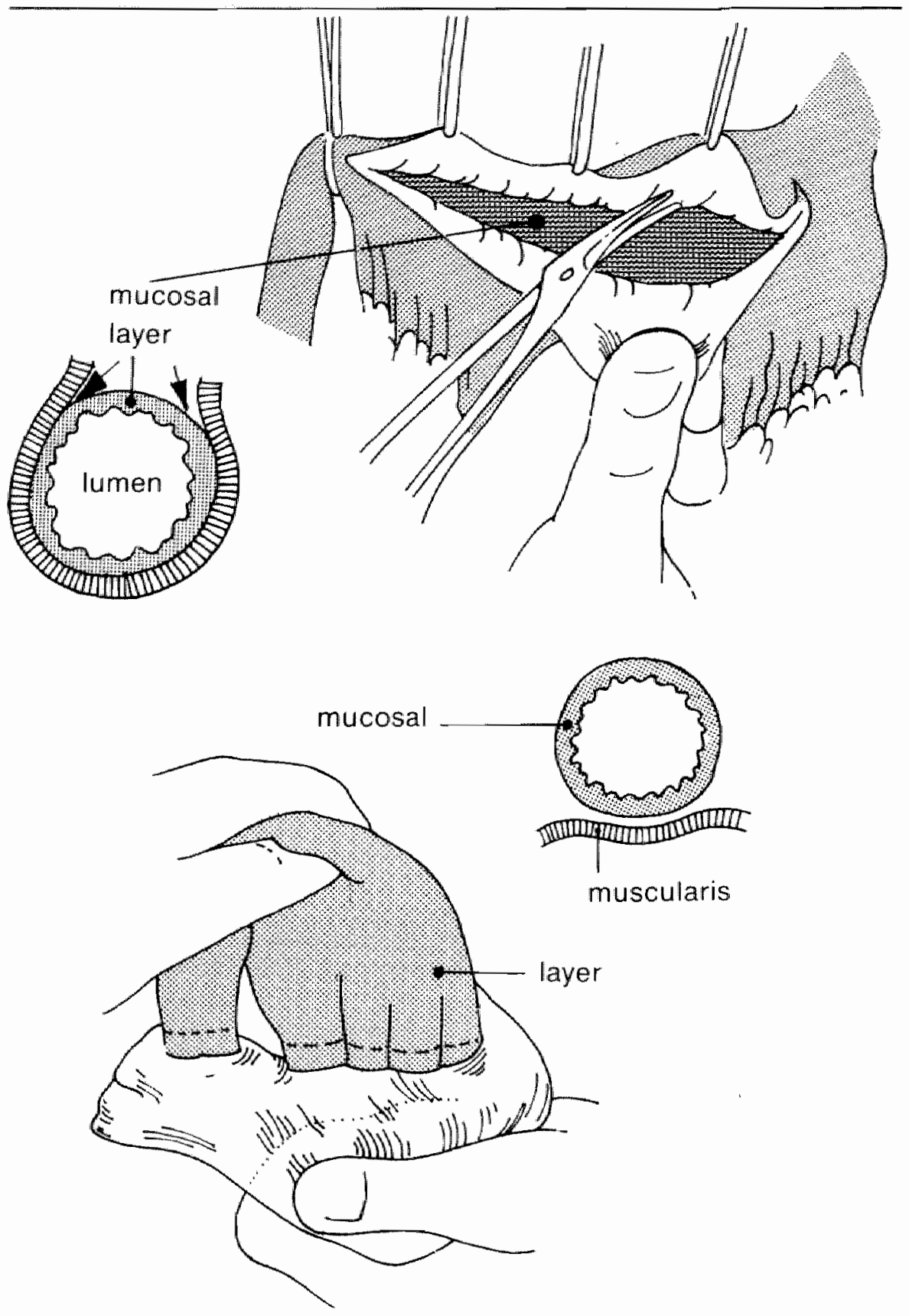

Figures $10+11$. Experimental Preparation.

A mucosal antrectomy of all antral mucosa is carried out. Note that the serosa is not incised entirely into the duodenum. The limitations of the antral mucosa are then clefined by pH paper to make certain that a complete mucosal antrectomy has been cartied out. 


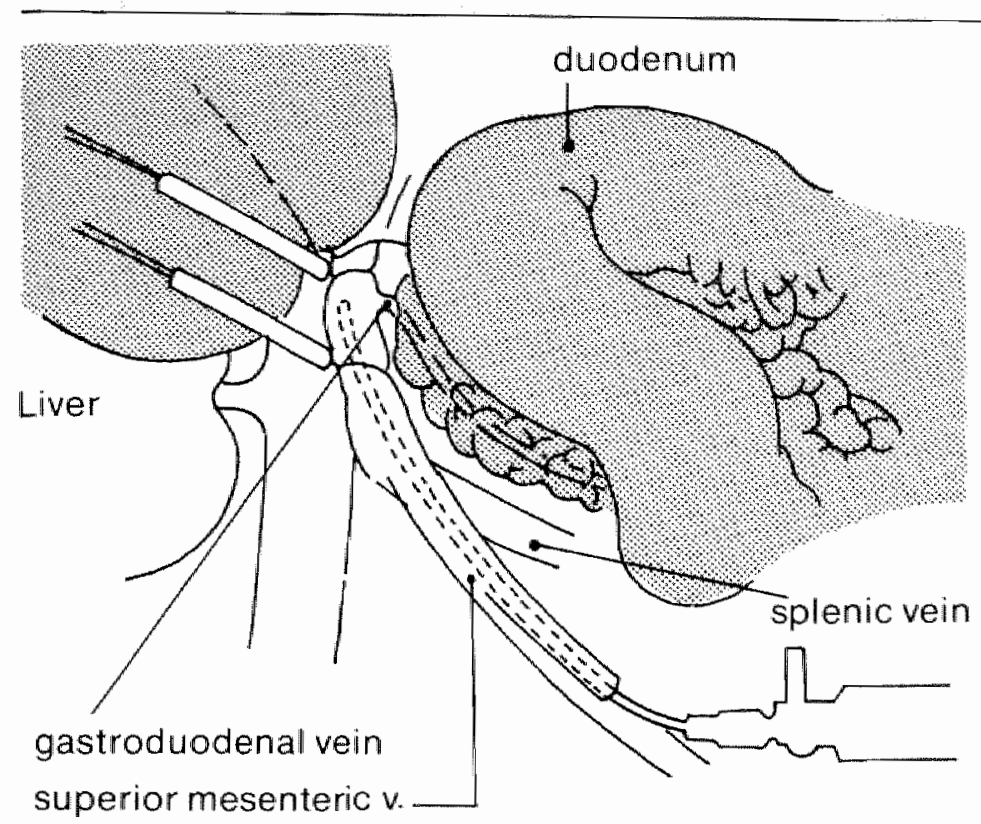

Figure 12. Cannulation of the Superior Mesenteric Vein with a fine silastic catheter as carried out in these experiments. The opening of the catheter is opposite the entrance of the gastroduodenal vein into the portal vein.

duodenal vein at $0,5,15,30,45,60$ and 90 minutes. A one hour rest period was taken between the different test periods, during which the plasma gastrin returned to basal levels.

1. Vagal stimulation was carried out with either 2-deoxy-D-glucose, $100 \mathrm{mg} / \mathrm{kg}$ bodyweight, intravenously as a bolus or with insulin hypoglycemia 0.5 units $/ \mathrm{kg}$ bodyweight, also given intravenousty as a bolus. During insulin hypoglycemia, samples for blood sugar were taken from the femoral vein at times when plasma samples for gastrin determination were collected from the gastroduodenal vein.

2. Locall perfusions were carried out for one hour with a Roller-pump at $60 \mathrm{cc} / \mathrm{hr}$ with $1 \%$ acetylcholine $(\mathrm{ACH})$ at either $\mathrm{pH} 7$ or acidified to $\mathrm{pH} 1.5$, with $0.4 \mathrm{M}$ glycine $(\mathrm{pH} 7)$, or physiological saline $(\mathrm{pH} 7)$. Perfusions were carried out so as not to increase pressure in the duodenum.

3. Distension was simulated with a thin wall latex balloon filled with saline at $37^{\circ} \mathrm{C}$ while intraduodenal pressure was monitored continuously by means of a strain gauge transducer (Sanborn $267 \mathrm{AC}$, Waltham, Massachusetts) and recorder (Sanborn 7700). Air was completely removed from the balloon and tubing and connections were flushed with saline to serve as a transmitter of pressure. Serial blood samples were obtained from the gastroduodenal vein (in attempts to measure possible release of gastrin), while intraduodenal pressure of 20,40 and $120 \mathrm{~cm}$ of water were maintained over a 20 minute period. Blood samples were obtained at $0,2,5,10,15$ and 20 minutes, and at 10 minutes intervals thereafter. Between every distension period, there was a 30 
minute rest period during which the balloon was deflated and plasma gastrin samples taken.

Blood samples were centrifuged immediately and stored at $-20^{\circ} \mathrm{C}$ before radioimmunoassay. Gastrin radioimmunoassay was performed using antibodies produced in rabbits after repeated immunization with SHG 2-17 conjugated to bovine serum albumin as previously described (40).

Statistical comparison of the results was carried out by use of uncorrelated Student t test. In the text, data are given as mean \pm SEM. The level of significance indicates a $p$ value of less than 0.05 .

\section{Results}

One hour after mucosal antrectomy, plasma gastrin levels fell significantly from $55 \pm 8.7 \mathrm{pg} / \mathrm{mll}$ to $17 \pm 2 \mathrm{pg} / \mathrm{mll}$ (figure 13 ).

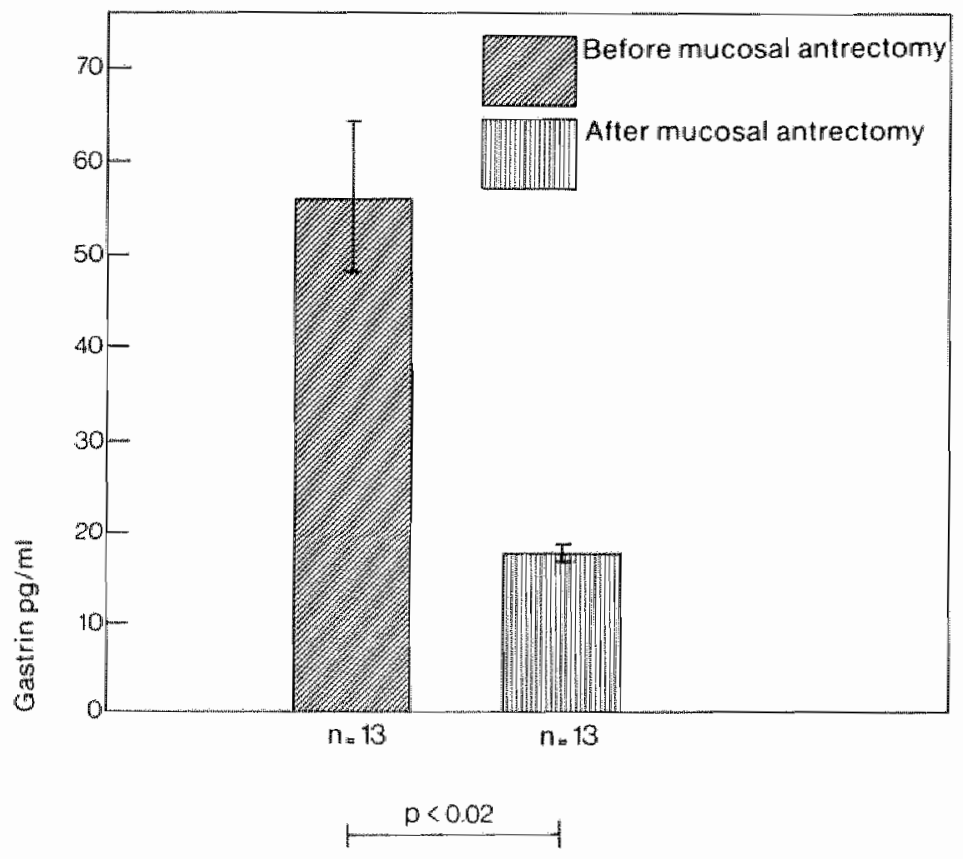

Figure 13. Plasma gastrin before: and after mucosal antrectomy. The decrease in basal plasma gastrin in these animals indicates a sigmificant contribution by amtral gastrin in these dogs. Riesults are given as mean \pm S. E. M. $(n=13) p<0.02$

Vagal stimulation - No measurable release of gastrin could be demonstrated after stimulation with 2-deoxy-D-glucose, while there was significant increase in the mean plasma gastrin level 45 minutes after stimulation with insulin hypoglycemia (figure 14). Blood sugars of less than $50 \mathrm{mg} / 100 \mathrm{ml}$ were obtained in response to all insulin hypoglycemia stimulations. 


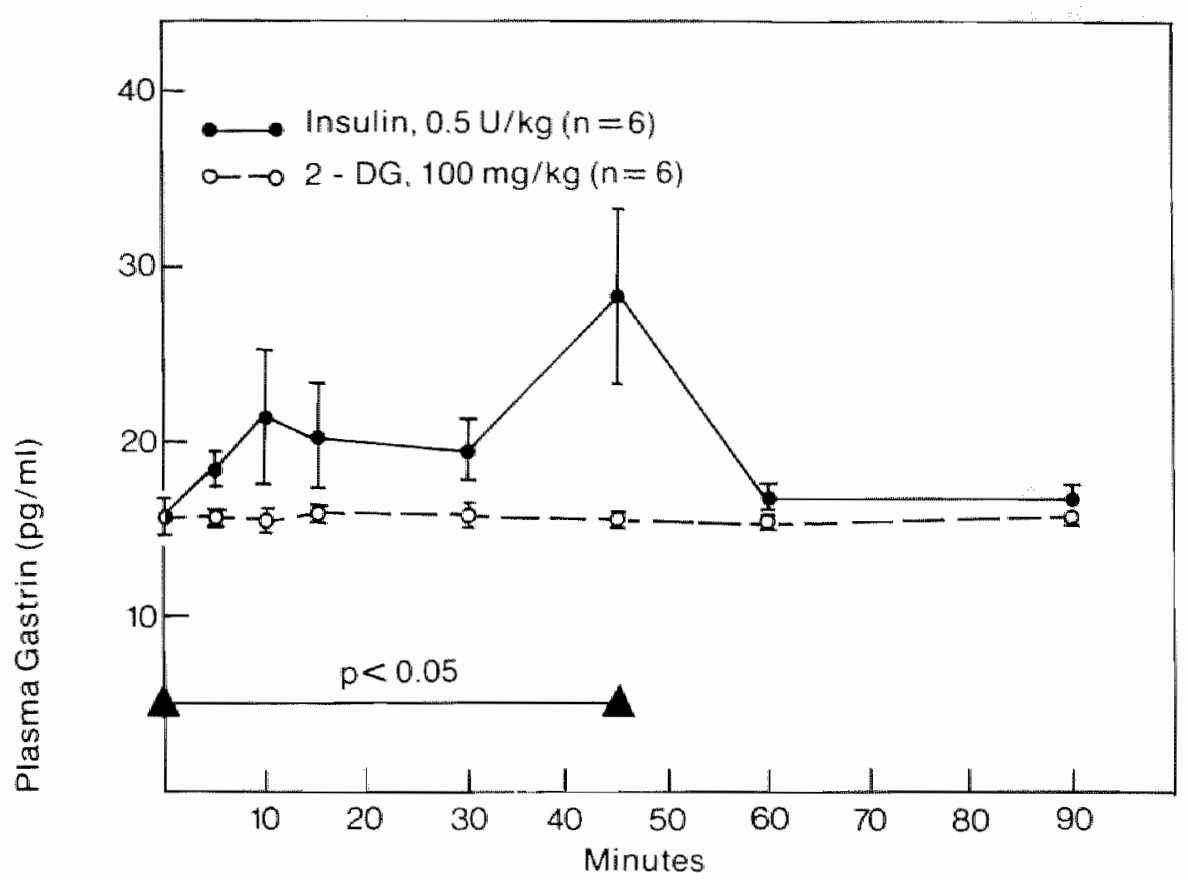

Figure 14. Release of gastrin with wagal stimulation. Unsulin hypoglycemia 0.5 units/kg or 2-deoxy-Dglucose $100 \mathrm{mg} / \mathrm{kg}$ were given in a bolus ower 5 minutes. Samples were taken as indicated. The sample taken at 45 minutes is significantly elevated. Note that $2-$ deoxy $-\mathrm{D}-\mathrm{glucose}$ failed to increase pliasma gestrin in the glastroduodenal vein.

Local perfusion - Perfusion of the duodenum with physiological saline solution buffered to $\mathrm{pH} 7$ did not release duodenal gastrin, nor did $0.4 \mathrm{M}$ glycine solution, a known local stimulator of antral gastrin release. During local perfusion with $1 \% \mathrm{ACH}$, there was a significant release of gastrin 5 minutes after the application of $\mathrm{ACH}$ at $\mathrm{pH} 7$ which persisted at 15 and 45 minutes (Figure 15). No measurable increase in the plasma gastrin occured following perfusion with $1 \% \mathrm{ACH}$ acidified to $\mathrm{pH} 1.5$.

Pressure stimulation - No measurable amounts of gastrin were released during distension of the duodenum with an intraduodenal pressure of $20 ; 40$ or $120 \mathrm{~cm}$ of water (Figure 16).

\section{Discussion}

Gastrin containing G-cells have been demonstrated in the duodenum of man and laboratory animals by radioimmunoassay, bioassay and by radioimmunofluorescence as well $(1,2,8,74-79)$. However in man, relatively large amounts of gastrin are present in the duodenum (1), as compared with the dog (10), with a concentration in proximal duodenal mucosa of between 0.1 and 0.5 that of antral mucosa (22).

Recent clinical studies have suggested a major contribution of duodenal gastrin to basal and post-prandial plasma gastrin values $(9,11,80,81)$. After Billroth-I gastrectomy (i.e. after partial gastrectomy with gastroduodenostomy) basal and post-prandial plasma gastrin levels are as great as before antrectomy and significantly higher than after Billroth-ll gastrectomy (gastrojejunostomy)(9). 


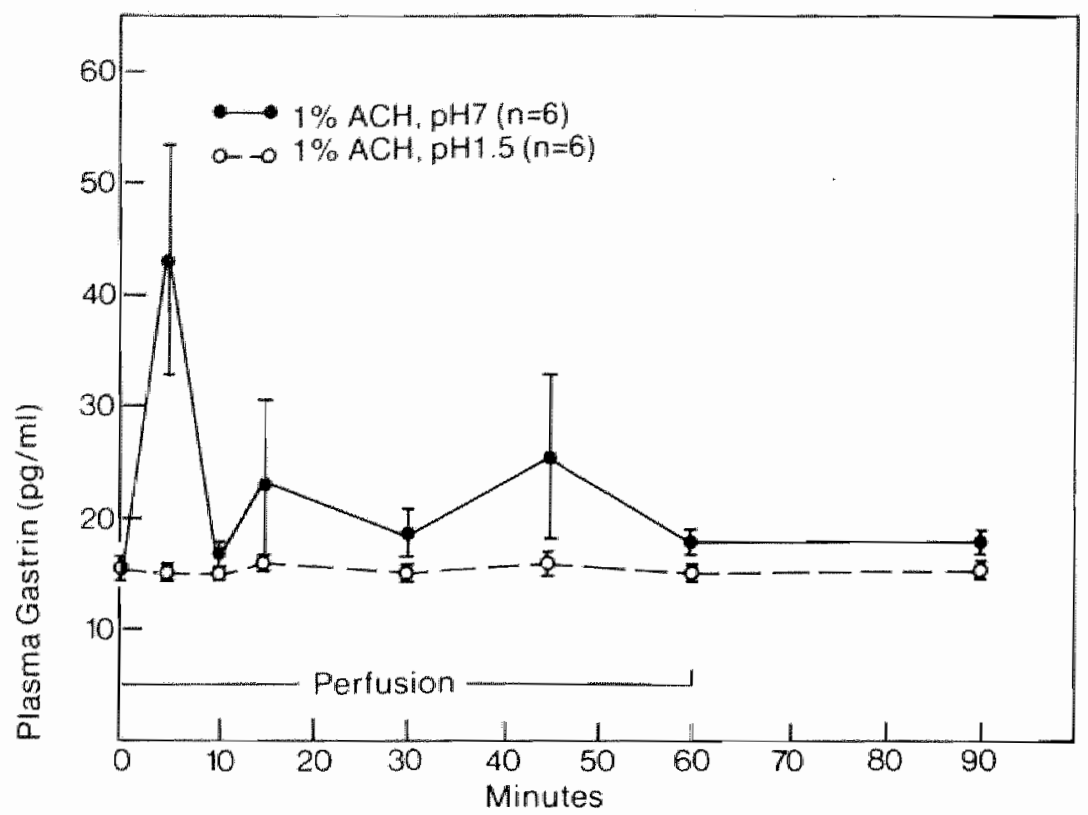

Figure 15. Duodenal perfusion with Acetylcholine at ph 7 and at pH 1.5. in which pertusion was carried out for one hour as shown. There was prompt release of gastrin at 5 minutes. When acetylcholine is perfused at pit 1.5, no elevation ing gastroduodenal vain gastrin could be detected.

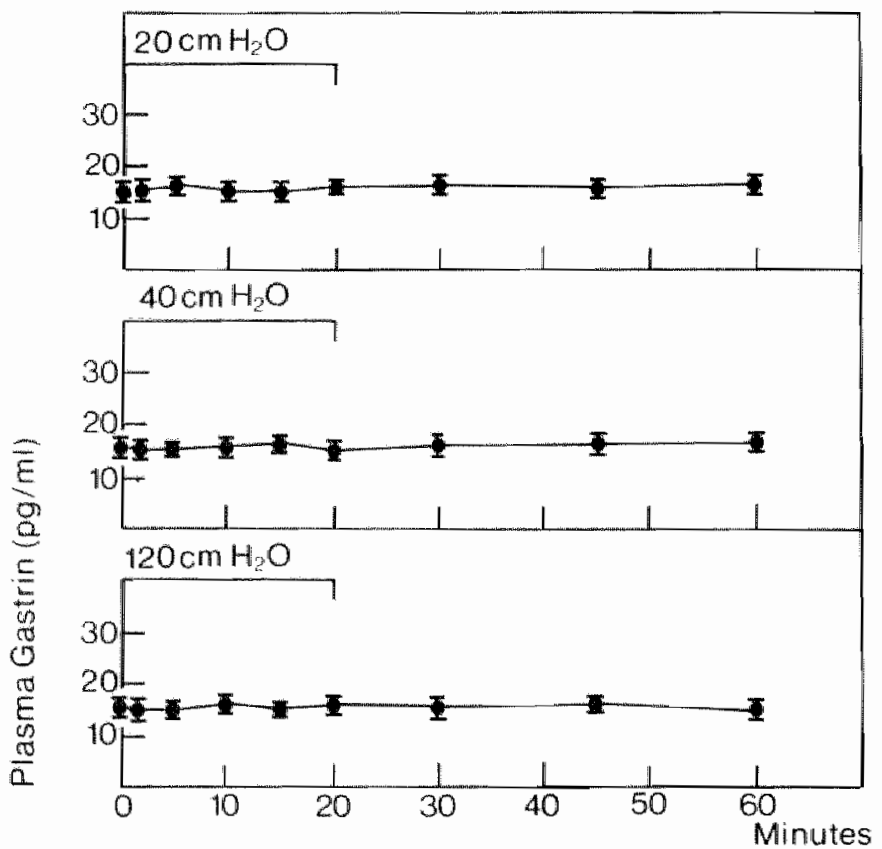

Figure 16. Balloon distension for 20 minutes at various pressures was carred out as described in the text in each of six dogs in randomized order. Following this, the animal was allowed to recower for 30 minutes, distension thereby being carried out at hourly intervals.

Note that there was no release of duodenal gastrin following balloon distension. 
This is in contrast to the dog where the increase in gastrin response to feeding is greatly decreased after antrectomy and gastroduodenostomy (12). Post-prandial plasma gastrin levels in duodenal ulcer patients with pyloric stenosis are reported to be considerably lower and with a later peak following meal stimulation than in patients with duodenal ulcer without stenosis of the pylorus (80). Korman, et al reported a significant rise in plasma gastrin levels following meal stimulation in patients following total gastrectomy and suggested that this was duodenal in origin (81). The characteristics of duodenal gastrin and its release have not been widely studied. Only, Becker and co-workers have shown a release of gastrin from a proximal, but not from a distal duodenal pounch, following perfusion with a $0.5 \% \mathrm{ACH}$ solution (82).

The present studies indicate that although the amounts of gastrin released from the canine duodenum are small, the characteristics of release of duodenal gastrin show some distinct differences from antral gastrin. While it would appear that duodenal gastrin is under cholinergic control, being released by insulin hypoglycemia, 2-deoxy-D-glucose failed to release duodenal gastrin. Battle, et al (83) recently reported similar characteristics for canine antral gastrin with release following insulin hypoglycemia, but not with 2-deoxy-D-glucose.

$\mathrm{ACH}$ at neutral $\mathrm{pH}$, but not $\mathrm{pH} 1.5$, resulted in prompt release of duodenal gastrin. This is similar to antral gastrin release, but the mechanism may be more complex.

In the stomach, an acid gastric $\mathrm{pH}$ is the most potent inhibitor of antral gastrin release and a neutral $\mathrm{pH}$ allows antral gastrin release. In the duodenum, however, the duodenal G-cells are generally surrounded by a neutral and sometimes alkaline milieu, thus perhaps allowing a constant low level release of duodenal gastrin as evidenced by the contribution of duodenal gastrin to basal levels. Acidification of the proximal duodenum results in release of secretin (84), and possibly other gastric acid and gastrin release inhibiting hormones $(74,85,86)$ which may have a direct effect on gastrin release. Thus, the faillure of $\mathrm{ACH}$ in acid to release gastrin from the duodenum could be due to failure of stimulation or to release of other hormones which in turn inhibited the release of duodenal gastrin. Further studies with direct measurements of plasma secretin levels and other hormones must be performed to clarify this mechanism. Duodenal perfusion with $\mathrm{ACH}$ falled to release cholecystokinin (82).

In contrast to the antral gastrin releasing mechanism, $0.4 \mathrm{M}$ glycine and distension, both of which are excellent releasers of antral gastrin in the dog (87), failled to release duodenal gastrin. The previously mentioned clinical studies made it likely that food, distension or perhaps some of the aminoacids could release duodenal gastrin in man. The failure for glycine and distension to do so in the dog mayreflect a species difference, the lack of an appropriate stimulus, or the smaller amount of gastrin present in the canine duodenum. These experiments, however, cannot be taken as excluding the role of distension of food in releasing duodenal gastrin, at least in man, or the conscious dog, as these experiments were performed under anesthesia. Failure to obtain release of duadenal gastrin (or intestinal) in the conscious dog by "food" "was reciently reported by Debas, et al (88), who perfused $15 \%$ liver 
extract into gastric fistulas in antrectomized dogs with gastroduodenal anastomoses. Serum gastrin was unchanged, suggesting that even in the conscious dog, duodenal gastrin may not be released by food.

The finding in this study are at variance with thase recently reported by Becker. et al (82). However the experimental techniques were quite dissimilar.

Whereas antral gastrin secreting mucosa was removed in this experiment, it was left intact but excluded from the experiment by "ligation of all venous anastomoses" between duodenum and antrum. something which in our opinion is difficult to achieve in view of the generous vascularity and complex anatomy of the area. Secondly, the pancreatic secretions were excluded in their experiments, but drained in these presently reported.

The results differ markedly as well, while Becker, et al do not indicate whether basal gastrin dropped after the experimental preparation was completed, basal levels dropped markedly following removal of antral mucosa in these experiments, suggesting a major contribution of antral gastrin in the dog. The basal levels reported by Becker, et al are 5-10 times obtained here, and may reflect technical differences in radioimmumoassay technique or a contribution by antral gastrin. Some contribution by antral gastrin is likely in Becker"s experiments as their basal values are similar to those reported by them in other experiments with intact antra $(89,90)$.

Recent experiments reported by the same group, using the same preparation, showed a significant drop in basal gastrin in a gastroduodenal vein when antrectomy followed venous disconnection (91).

We obtained no release following gllycine perfusion at neutral $\mathrm{pH}$. Becker and his co-workers reported some increase following glycine perfusion, which was considerably less than following $\mathrm{ACH}$ and simillar in magnitude to that obtained following proximall duodenal perfusion with saline, which resulted in no release in these experiments.

These findings do confirm the suggestion that canine duodenal gastrin is of less consequence than in man, and that total antrectomy in the dog abolishes the post-prandial gastrin reponse (82), a finding which would be in agreement with failure of glycine and distension, as shown here, to release duodenal gastrin, in spite of the presence of intact vagal innervation. Similarly, total gastrectomy in the dog all but abolishes serum gastrin reponse to feeding (90).

The molecular form of gastrin released in these experiments has not been identified in these studies. Recently, Malmstrom et al (9) have shown that G-17 and G-34 each made up half of the immunoreactive gastrin of the duodenum of man. The antibodies used in the experiments currently reported seem capable of recognizing both $\mathrm{G}-17$ and $\mathrm{G}-34$. We do not know, however, whether big-biggastrin is recognized by our antibody, and insufficient amounts of gastrin were present in the gastroduodenal plasma sample to accurately assay the molecular species released, by column-chromatography.

These findings suggest that in anesthetized dogs, only $\mathrm{ACH}$ at neutral pH or insulin hypoglycemia can release duodenal gastrin. Duodenal distension and $0.4 \mathrm{M}$ glycine, failed to release duodenal gastrin in these experiments. This is in contrast to the results of some clinical studies, and probably reflects species differences. In the anesthetized dog, some physiological stimuli effective for antral gastrin release do not result in release of duodenal gastrin. 


\section{Actions of gastrin}

Although gastrin is known to have quite a wide spectrum of pharmacological actions on the intestinal tract (92-94), there is less certainty about the physiological nature of such actions. No doubt exists, however, about the importance of gastrin stimulation of the acid secreting parietal cells. The stimulation of acid secretion is achieved, through a more intricate mechanism than was previously suspected $(32,94)$.

This involves a complex interaction on the three major receptors of the parietal cells, namely those of gastrin, $\mathrm{ACH}$ and histamine. It has been shown that blockade of either the $\mathrm{ACH}$ receptor (by atropine) (95) or the histamine receptor (by metiamide) (96) or other antagonists, also blocks the action of gastrin on the parietal cell receptor. The clinical importance of this observation is appreciated by observing the effectiveness of a highly selective vagotomy in reducing acid secretion in spite of the accompanying 2 to 3 foll increase of gastrin release $(32,97)$.

While injected or endogenous gastrin will "result" in the stimulation of pepsin secretion (93), this apparent stimulation of pepsin secretion seems to be secondary to the resulting acidity ( 98$)$.

Whereas the physiological importance of gastrin in the regulation of gastric acid secretion is soundly established, it is not always clear whether its other effects have a physiological or clinical importance.

Nonetheless, it is reasonable to consider physiological any gastrim effect obtained at the minimal dose needed to stimulate acid secretion. Alternatively, the peak gastrin response seen in a post-prandial situation, could similarly be used as a guide.

With such criteria, only pepsin secretion, the stimulation of gastric mucosal blood flow and its trophic action seem to satisfy these criteria (22).

The biological potentials of gastrin include actions $(82-94,99)$ such as the stimulation of water and electrolyte secretion from the stomach, pancreas, liver and small intestines, increased visceral blood flow, trophic actions, stimulation of the lower esophageal sphincter and stomach, relaxation of the pyloric sphincter and the release of other hormones such as insulin (100) and calcitonin (101), as well as VIP (102).

It is difficult to accept, therefore that gastrin's physiological role is confined to two or three functions. The study of the effect of gastrin on the lower esophageal sphincter (LES) is such an example. Gastrin has been known to stimulate the LES $(94,103)$. This has been regarded by some as physiological $(103,104)$ and has been denied by a number of other investigators (105-107) One point remains certain in that context, and this is the rarity of reflux esophagitis in the ZE - syndrome (108). This, however, could be attributed to a trophic effect of gastrin on the physiological sphincter $(109,110)$.

Marked hyperplasia of the gastric mucosa, the number of parietal cells and the capacity to secrete acid may be increased as much as six times normal (109),

Singlle doses of gastrin stimulate synthesis of DNA, RNA and protein and cause a burst of mitotic activity reaching a peak about 12 hrs after the injection (109). The clinical studies of hypergastrinemia syndrome are in fact, extremely useful in the study of gastrin's effect in man.

Among the effects of gastrin that are seen in the ZE-syndrome are the following: the above mentioned parietal cell hyperplasia, increased pancreatic secretion 
with increased basal and stimulated wolume and bicarbonate output $(112,113)$ and diarrhea which could result from a direct action of gastrin on intestinal water and electrolyte transport inhibition or secretion, but which is more likely the result of the steatorthea seen in the ZE patients (114), suggesting that increased circulating levels of gastrin result in these physiological activities.

\section{Metabolism of gastrin}

Most of the information available concerning metabolism of gastrin in wivo has been obtained in dogs, but enough is known about metabolism in man to suggest that there are no marked differences.

As mentioned before, gastrin metabolism is somewhat dependent on the size of the molecule. In dogs, the half life of infused $\mathrm{G}-17$ and $\mathrm{G}-34$ was measured and found to be 3 and 15 minutes respectively (115). In similar experiments, the half life of $\mathrm{G}-13$ in dogs was about the same as that of $\mathrm{G}-17$ (116).

Recently, the half lives of G-17, G-34 and BBG obtained from human tumor extract were determined and found to be approximately 3,9 and 90 minutes respectively (117).

A conscensus is that the larger forms of gastrin are less readily metabolized than the smaller and biologically more active molecules, and thus have a longer half life.

The kidneys are well established as a major site of accumulation and degradation of many peptide hormones including gastrin. Approximately $40 \%$ of exogenous synthetic human gastrin (118) and $30 \%$ of stimulated endogenous dog gastrin $(119,120)$ is extracted from the renal artery plasma in a single pass through the kidney. Very little gastrin appears in the urine, so that the peptide is presumably metabolized within the kidney.

An enzymatic activity has been described in perfused rat kidney that catalyzed cleavage of the C-terminall glycinamide from oxytocin and vasopressin (121). Another activity was found in rat kidney homogenates that cleaved the C-terminal dipeptide amide, Asp - Phe - $\mathrm{NH}_{2}$ from gastrin tetrapeptide (122). It is not known, if either one or both these enzymes are active against whole gastrin. In a clinical study, which is extensively discussed in chapter III, we, as well as others have reported increased plasma gastrin levels in patients with renal failure and in nephrectomized patients (123-125), what could account for the upper Gl ulceration and bleeding seen in uremic patients (124-126). However, the clearance of $\mathrm{G}-17$ is too rapid to be explained entirely by renall extraction, indicating that other organs participate in the metabolism of this form of gastrin.

The small intestine also seems to have a role in glastrin metabolism $(127,128)$. Jejuno-ileal bypass does not result in hypergastrinemia (129), while marked hypergastrinemic responses to feeding have been seen in patients with massive intestinal resection (127). Although it was not established whether these last patients had an abnormal metabolism or increased release of gastrin. The role of the liver in gastrin metabolism is still unsettled. Gastrin secreted by antral and intestinal G-cells must trawerse the liver before reaching the target organs. Negligible amounts of gastrin are transported in the lymphatic system (130). In a recent human study (131), no significant difference was found between gastrin concentrations measured in the umbilical vein and the antecubital vein, 
Which agrees with most other studies in that the liver seems to play a minor part in the nactivation of $\mathrm{G}-17$. And although the metabolism of $\mathrm{G}-34$ by the liver has not been studied directly, relative abundance of $\mathrm{G}-17$ and $\mathrm{G}-34$ in portal and hepatic vein does not differ (131). In contrast, the liver actively removes shorter. biologically active gastrin fragments from the portal circulation, including the tetrapeptide and pentagastrin (132).

The lung apparently has little effect in the catabolism of gastrin (133).

\section{References}

\section{Nilsson G., Yalow R.S. and Berson S.A.}

Distribution of gastrin in the gastrointestinal tract of human, dog, cat and hog in "Frontiers in Gastrointestinal Hormone Research" "Ed. Anderson published by Almquist and Wiksell, Stockholm, pp. 95,1973.

2 Creutzfeldt W., Creutzfeldt C. and Arnold R.

Gastrin producing cells in "Endocrinology of the Gut". Ed. Chey and Brooks, published by Charles B. Slack \|nc. N.J. pp. 35,1974.

3 McGuigan J.E. and Greider M.H.

Correlative immunochemical and light microscopic studies of the gastrin cell

of the antral mucosa.

Gastroenterology 60:223,1971

4 Solcia E., Vassallo G. and Sampietro R.

Endocrine cells in the antropyloric mucosa of the stomach.

Z. Zellforsch. Mikrosk.Anat. 81:474,1967.

5 Greider M.H., Steilnberg V. and McGuigan J.E.

Electron microscopic identification of the gastrin cell of the human antral mucasa by means of immunocy tochemistry.

Gastroenterology 63:572,1972.

\section{Pearse A.G.E.}

Cytochemical and Ultrastructural Characteristics of cells Producing

Polypeptide Hormones and their relevance to Gut Hormones.

In "Endocrinology of the Gut" Ed. by Chey and Brooks, published by Charles B.

Silack Inc. pp. 24,1974.

7 Creutzfeldt W., Arnold R., Creutzfeldt C.

Gastrin and $G$-cells in antral mucosa of patients with pernicious anemia, acromegaly and hyperparathyroidism in a Zollinger-Ellison tumor of the pancreas.

Eur.J.Clin.Invest. I:461, 1971.

8 Berson S.A., Yalow R.S.

Nature of immunoreactive gastrin extracted from tissues of gastrointestinal tract.

Gastroenterology 60:215, 1971 .

9 Malmstrøm J., Stadil F. and Rehfeld J.R.

Concentrations and component pattern in gastric, duodenal and jejunal

mucosa of normal human subjects and patients with duodenal ulcer.

Gastroenterology 70:697,1976.

10 Watson L.C., Reeder D.D., Becker H.D., Lagrae L. and Thompson J.C.

Gastrin concentrations in upper gastrointestinal mucosa in dogs.

Surgery $76: 419,1974$.

11 Stern D.H. and Walsh J.H.

Gastrin release in postoperative ulcer patients: evidence for release of duodenal gastrin.

Gastroenterology $64: 363,1973$. 
12 Sjödin L. and Nilsson $G$.

Plasma gastrin and gastric acid responses to test meals in dogs following resection of antrum and duodenal bulb.

Abstr. Vth World Congress of Gastroenterology. Mexico, pp. 133,1974.

13 Greider M.H. and McGuigan J.E.

Cellular localization of gastrin in the human pancreas.

Diabetes 20:389,1971.

14 Levant J.A., Walsh J.H. and Isenberg J.L.

Stimulation of gastric secretion and gastric release by single oral doses of calcium carbonate in man.

N.Engl.J.Med. 289:555,1974.

15 Dockray G.J. and Walsh J.H.

Aminoterminal gastrin fragment in serum of Zollinger-Ellison syndrome patients.

Gastroenterology 68:222,1975.

16 Korman M.G., Soveny C. and Hansky J.

Effect of food on serum gastrin evaluated by radioimmunoassay.

Gut 197:12,619,1971.

17 McGuigan J.E, and Trudeau W.L.

Studies with antibodies to gastrin: radioimmunoassay in human serum and physiological studies.

Gastroenterology 58:139,1970.

18 Debas H.T., Konturek S.J., Walsh J.H. and al.

Proof of a pyloro-oxyntic reflex for stimulation of acid secretion.

Gastroenterology 66:526,1974.

19 Debas H.T., Walsh J.A. and Grossman M.I.

Evidence for oxynto-pyloric reflex for release of antral gastrin.

Gastroenterology 68:687,1975.

20 Debas H.T., Csendes A., Walsh J.H. and Grossman M.ll.

Release of antral gastrin. In "Endocrinology of the Gut". Ed. Chey \& Brooks, published by Charles B. Slack Inc. pp.222,1974.

21 Bergegârdh $S$. and Olbe L.

Gastric acid response to distension of the stomach in man.

Acta Physiol Scand. 82:6A, 1971.

22 Walsh J.H. and Grossman M.I.

Gastrin (first of two parts)

New Eng.J.of Med. 292:1324,1975.

23 Nillsson G., Simon J., Yalow R.S. and Berson S.A.

Plasma gastrin and gastric acid responses to shamfeeding and feeding in dogs.

Gastroenterology 63:51,1972.

24 Tepperman B.L., Walsh J.H. and Preshaw R.M.

Effect of antral denervation on gastrin release by shamfeeding and insuin

hypoglycemia in dogs.

Gastroenterology 63:973,1972.

25 Csendes A., Walsh J.H. and Grossman M.I.

Effects of atropine and of antral acidification on gastrin release and acid secretion in response to insulin and feeding in dogs.

Gastroenterology 63:257, 1972.

26 Knutson U., Olbe L. and Ganguli P.C.

Gastric acid and plasma gastrin response to shamfeeding in duodenal ulcer patients before and after resection of the antrum and the duodenal bulb.

Scand.J.Gastroent. 9:351,1974.

27 Mingnon M., Calmiche J.P., Accary J.P. and Bonfils S.

Serum gastrin, gastric acid and pepsin response to shamfeeding in man.

Gastroenterology 66:856, 1974 . 
28 Olbe L.

Potentiation in shamfeeding response in Pavlov pouch dogs by subtreshold amounts of gastrin with and without acidification of denervated antrum. Acta Physiol.Scand. 61:224,1964.

29 Olbe L.

Effect of resection of gastrin releasing regions on acid response to shamfeeding and insulin hypoglycemia in Pavlow pouch dogs.

Acta Physiol. Scand. 62:169,1964.

30 Brooks F.P. and Lanciault G.

The role of the vagus nerve in gastrin release. In "Endocrinolagy of the Gut" Ed. by Chey \& Brooks, published by Charles B. Slack Inc. pp. 233,1974.

31 Maher J.W., Wickborn G., Woodward E.R., McGuigan J.E. and Dragstedt L.R.

The effect of vagal stimulation on gastric release and acid secretion. Surgery $77: 255,1975$.

32 Becker H.D., Reeder D.D. and Thompson J.C.

Vagal control of gastrin release.

In "Symporium on Gastrointestinal Hormones" Ed. by Thompson, published by University of Texas Press, pp.437,1975.

33 Wallsh J.H., Yalow R.S., Berson S.A.

The effect of atropine on plasma gastrin response to feeding.

Gastroenterology 60:16,1971.

34 Farooq O. and Walsh J.W.

Atropine enhaces serum gastrin response to insulin in man.

Gastroenterology 68:662,1975.

35 Smith C.L., Kewenter J., Conell A.M., Ardill J., Hayes R. and Buchanan K. Control factors in the release of gastrin by direct electrical stimulation of the vagus.

Am.J.Dig.Dis. 20(1):13,1975.

36 Stadil F. and Rehfeld J.F.

Gastrin response to insulin after selective, highly selective and truncal vagotomy.

Gastroenterology 66:7,1974.

37 Hayes J.R., Ardill J., Kennedy T.C. et al

Stimulation of gastrin release by catecholamines.

Lancet $1: 819,1972$.

38 Stadill F. and Rehfeld J.E.

Release of gastrin by epinephrine in man.

Gastroenterology 65:210,1973.

39 Thompson J.C., Rayford P.L., Ramus H.I., Fender R.H., and Villar H.V.

Patterns of release and uptake of heterogeneous forms of gastrin.

In "Symposium on Gastrointestinal Hormones" Ed. by Thompson,

published by University of Texas Press, Austin pp. 125, 1975.

40 Schofield B., Kende E.M., Tepperman B.C. and Tepperman F.S.

Release of gastrin from dog antral mucosa - in vitro - by acetylcholine.

In " Symposilum on Gastrointestinal Hormones". Ed. by Thompson, published by University of Texas Press, Austin pp.491,1975.

41 Wesdorp R.I.C., Funovics J.M., Hirsch H., Fischer J.E.

Characteristics of release of duodenal gastrin.

Surgical Forum XXVI, 383, 1975

42 Dent R.I., James H.J., Wang C.A., Deftos L.J., Talamo R. and Fischer J.E. Hyperparathyroidism, gastric acid secretion and gastrin.

Annals of Surgery $176: 3,660,1972$.

43 Wesdorp R.I.C., Wang C.A., Hirsch H. and Fischer J.E.

Plasma and parathyroid tumor tissiue gastrin and hyperparathyroidism. 
Am.J.Surg. 131:60,1976

44 Woodward E.R. and Shapiro $H$.

Effect of local anesthetics on the isolated antrum of the stomach in dogs.

Am.d. of Physial. 192(3):479, 1958.

45 Way L., Goldman L. and Dunphy J.E.

Zollinger-Ellison Syndrome. An analysis of 25 cases.

Am.J.Surg. 116:293,1968.

46 Jackson B.M., Reeder D.D., Thompson J.C.

Dynamic characteristics of gastrin release.

Arn.J. of Surg. 123,137,1972.

47 Csendes A., Walsh J.H. and Grossman M.I.

Effects of atropine and antral acidification on gastrin release and acid secretion in response to insulin and feeding in dogs.

Gastroenterology 63:257,1972.

48 Chayvialle J.A., Lambert R., Tonillon C. and Moussa F.

Antral acidification and gastrin release in man.

In "Symposium on Gastrointestinal Hormones". Ed. by Thompson,

published by University of Texas Press, Austin, pp.447,1975.

49 Redford M. and Schofield B.

The effect of local anesthesia of the pyloric antral mucosa on acid inhibition of gastrin mediated acid secretion.

J.Physiol. (London) 180:304,1965.

50 Waisn J.H., Richardson C.T. and Fordtran S.

$\mathrm{pH}$-Dependence of acid secretion and gastrin release in normal and ulcer subjects.

J.Clin.Invest. 55:462,1975.

51 Higgs R.H., Smyth R.O., Castell D.O.

Gastric alkalinization and effect on lower esophageal sphincter pressure and serum gastrin.

N.Engl.J.Med. 291:486,1974.

52 Hansky J.

Pathophysiology of gastrin.

In "Endocrinology of the Gut". Ed. Chey \& Brooks by Charles B. Slack Inc., New Jersey pp.304,1974.

53 Yalow R.S. and Berson S.A.

Further studies on the nature of immunoreactive gastrin in human plasma.

Gastroenterology 60:203,1971.

54 Yalow R.S., Berson S.A.

Radioimmunoassay of gastrin.

Gastroenterology 58:1,1970

55 Dreiling D.A. and Greenstein A.

Pancreatic function in patients with Zollinger-Ellison syndrome.

Med Chir.Dig $1: 1,1975$.

56 Grennlee H.B., Loughi E.H., Guerno J.H., Nelson T.S., El-Babri A.L. and Dragstedt L.R.

Inhibitory effect of pancreatic secretin on gastrin secretion.

Am.J. Physiol. 190:396,1957.

57 Said S.I.

Vasoactive Intestinal Peptide (VIP)

Gastroenterology 67:735,1974.

58 Villar H.V., Fender H.R., Rayford P.L., Ramus N.I. and Thompson J.C.

inhibition of gastrin release and gastric secretion by GIP and VIP.

In "Symposium on Gastrointestinal Hormones". Ed. by Thompson, published by University of Texas Press, Austin, pp.467,1975.

59 Bloom S.R., Polak J.M. and Pearse A.G.E. 
Vasoactive intestinal peptide and watery diarthea syndrome Lancet 11: 14,1973.

60 Said S.I. and Falloona G.R.

Elevated plasma and tissue levels of vasoactive intestinal peptide in the watery diarrhea syndrome due to pancreatic, bronchiogenic and other tumors.

N.Eng.J.Med. 293(4):155,1975.

61 Fahrenburg J., Hovnum I. and Rehfeld J.F.

Effect of calcitonin on serum gastrin concentrations and component pattern in man.

J.Clin. Endocrinol. Met. 41(1):249, 1975.

62 Becker H.D., Reeder D.D., Scurray M.T. and Thompson S.C.

Inhibition of gastrin release and gastric secretion by calcitonin in patients with peptic ulcer.

Am.J.of Surg. 127:71,1974.

63 Bedi B.S., Debas H.T., Gilespie G., et al.

Effects of Bile Salts on Antral Gastrin Release.

Gastroenterology 60:256,1971.

64 Nyhuys L.M., Chapman N.D. DeVito R.V. and Harkins $\mathbb{H}$. N.

An Experimental Study IIlustrating a New Concept.

Gastiroenterology 39:582,1960.

65 Baldessarini R.J. and Kopin I.J.

The Effect of Drugs on the Release of Norepinephrine-Hafrom Central Nervous System Tissues by Electrical Stimulation in Vitro.

J.of Farm. and Exp. Ther. 156:31,1967.

66 Robertson G.R., Langlois K., Martin G.G. et al.

Rellease of Gastrin in Response to Bathing the Pyloric Mucosa with

Acetylcholine.

Am.J.Physiol. 163:27, 1950.

67 Krebs H.A.

Body Size and Tissue Respiration.

Bioch. et Bioph. Acta 4:249, 1950.

68 Elwin C.E. and Nilsson G.

Comparison of the Effect on Gastric Acid Secretion of Some Protein

Compounds Releasing Gastrin.

Acta Physiol.Scand. 59:37,1963.

69 Kolts B.E... and McGuigan J.E.

Radioimmunoassay of Secretin: Serum Concentrations and Half Life in Man.

Gastiroenterology $66: 849,1974$.

70 Sharp R., Culbert S., Cook J. et al.

Cholinergic Modification of Glucose Induced Biphasic Insulin Release In Vitro.

The J. if Clin. Invest. $53: 710,1974$.

71 Sheballin M., Brooks A.M., Said S.I. et al.

The Insulinotropic Effect of Vasoactive Intestinal Peptide (VIP). Direct evidence from in vitro studies (abstract).

Gastroenterology 66:772,1974.

72 Fritsch W.P., Hausamen T.U. and Rick W.

Gastric and extra glastric gastrin release in normal subjects in duodenal ulcer patients and in patients with partial gastrectomy (Bill roth I).

Gastroenterology $74: 552,1976$.

73 Kirk R.M.

Mucosal antrectomy in the treatment of peptic ulcer.

Proc.Roy.Soc. of Med. 59:571,1966.

74 Brown J.C., Dryburgh J.R., Pederson R.A.

Gastric inhibitory polypeptide in "Endocrinology of the Gut". Ed. by Chey \&

Brooks, published by Charles B. Slack Inc. pp.76, 1974. 


\section{Uvnäs $B$.}

The presence of a gastric secretory excitant in the human gastric and duodenal mucosa.

Acta Physiol Scand. 10:97,1945.

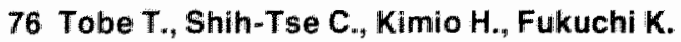

Distribution of gastrin in canine, cat and human digestive organs.

Am.J.of Surg. 132:581,1976.

77 Emăs S., Borg I., Fyro B.

Antral and duodenal gastrin activity in non-ulcer and ulcer patients.

Scand J.Gastroent. 6:39,1971.

\section{Lai K.S.}

Studies on gastrin 1I. Quantitative study of the distribution of gastrin-like activity along the gut.

Gut 5:334,1964.

79 Elwin C.E., Uwnäs B.

Distribution and local release of gastrin in" "Gastrin", Ed. by Grossman, published by University of California Press, pp.69, 1966.

80 Hayes J.R., Ardill J., Kennedy T.L. et al.

A duodenal role in gastrin release.

Gut 15:626,1974.

81 Korman $M_{\text {. }} G_{\text {, }}$, Soveny $C_{\text {, , Hansky I. }}$

Extragastric gastrin.

Gut 13:346, 1972.

82 Becker H.D., Reeder D.D., Thompson J.C.

Direct management of gastrin release from duodenum and jejunum in dogs.

Am.d.Physiol. 227:897,1974.

83 Battle W.S., Archer R., Slavi S.M., Ziaja B.A., Nyhus L.M., Bombeck C.T.

The effect of vagotomy on resting and stimulated serum gastrin levels. J.of Surg.Res. 16:346, 1974.

84 Boden G... Chey W.Y.

Preparation and specificity of antiserum to synthetic secretin and its use in a radioimmunoassay.

Endocrin. 92:1617,1973.

85 Said S.I., Makhlouf G.M.

Vasoactive intestinal peptide: Spectrum of biological activity in " Endocrinology of the Gut", Ed. by Chey \& Brooks, published by Charles B. Slack Inc.

pp.83,1974.

36 Villar H.V., Fender H.R., Rayford P.C., Bloom S.R., Ramus N.I. and Thompson J.C.

Suppression of gastrin release and gastric secretion by gastric inhibitory polypeptide (GIP) and vasoactive intestinal polypeptides (VIP).

Ann.Surgery 184:97, 1976.

\section{McGuigan J.E.}

On the distribution and release of gastrin.

Gastroenterology 64:497,1973.

88 Debas H.T., Slaff G.F., Grossman M.I.

Intestinal phase of gastric acid secretion; augmentation of maximal response of Heidenhain Pouch to gastrin and histamine.

Gastroenterology 68:691,1975.

89 Jackson B.M., Reeder D.D., Thompson J.C.

Dynamic characteristics of gastrin release.

Am.J.Surg. 123: 137, 1972 .

90 Miller J.H. Jackson B.M., Thompson J.C.

Effect of total gastrectomy and portal evisceration on circullating gastrin concentration. 
Surg. Forum 21:294,1970.

91 Villar H.V., Llanos O.L., Konturek S.J.

Release of antral and duodenal gastrin in response to an intestinal meal.

Gastroenterology 70:840,1976.

92 Gillespie I..E.

Gastrin in "Recent advances in Surgery". Ed. Taylor published by J\&A Churchill Ltd, London pp. 453,1969.

93 Grossman M.I.

Spectrum of biological actions of gastrointestinal hormones.

In Nobel Symposium 16: "Frontiers in Gastrointestinal Hormone Research".

Ed. Anderson published by Almquist \& Wiksell, Stockholm pp. 17.1973.

94 Makhlout G.M.

The neuroendocrine design of the gut.

Gastroenterology 67:159,1974.

95 Konturek S.J., Wysocki A. and Olesky J.

Effect of medical and surgical vagotomy on gastric response to graded doses of pentagastrin and histamine.

Gastroenterology 54:392,1968.

96 Gibson $R_{x,}$ Hirschowitz B.I. and Hutchinson $G_{\text {. }}$

Actions of metiamide, on $\mathrm{H}_{2}$ histamine receptor antagonist, or gastric + , and pepsin secretion in dogs.

Gastroenterology $67: 93,1974$

97 Fischer J.E., Kragelund E., Nielsen A. and Wesdorp R.I.C.

Basal and meatextract plasma gastrin before and after parietal cell vagotomy and selective gastric vagotomy with drainige in patients with duodenal ulcer. Ann.Surg. 183(11): 167,1976 .

98 Johnson L.R.

Effect of gastric mucosal acidification on the action of pepsigogues.

Am.J.Physiol. 1335:1411,1973.

99 Johnson L.R., Lichtenberger L.M., Copeland E.M., Dudrick S.J. and Castro G.A.

Actions of gastrin on gastrointestinal structure and function.

Gastroenterology 68:1184,1972.

100 Rehfeld J.F.

Gastrointestinal hormones and insulin secretion.

Scand.J.Gastroent. 7:289, 1972,

101 Care A.D., Bates R.F.C., Bruce J.B., Swammathan R., Bloom S. and Ganguli P.C.

Stimulation of calcitonin secretion by gastrointestinal hormones.

J. Endocrinol. 52:27,1972.

102 Ebeid A.M. and Fischer J.E.

Gastrin and ulcer disease: what is known.

in press 1977.

103 Cohen S. and Lipschutz W.

Hormonal regulation of human lower esophageal sphincter competence:

Interaction of gastrim secretion.

J.Clin.lnvest. 50:449,1971.

104 McCall I.W., Harvey R.F., Owens C.J. and Clendinnen B.G.

Relationship between changes in plasma gastrin and lower esophageal sphincter pressure after meals.

Br.J.Surq. 62(1):15,1975.

105 Dodds W.J., Hogan W.J., Miller W.N., Barreras R.F., Arndorfer R.C. and Stieff J.J.

Relationship between serum gastrin concentration and lower esophageal sphincter pressure. 
Am.J.Dig.Dis 20(3):201,1975.

106 Goyal R.K. and McGuigan J.E.

Fallure of gastrin antiserum to influence lower esophageal sphincter pressure: A double-blind controlled study.

Gastroenterology 68:951,1975.

107 Wright L.F., Slaughter R.L., Gibson R.G. and Hirschowitz B.l.

Correlation of lower esophageal sphincter pressure and serum gastrin level in man.

Am.J.Dig.Dis 20(7):603,1975.

108 Isenberg J., Csendes A. and Walsh J.A.

Resting and pentagastrin stimulated gastro-esophageal sphincter pressure in patients with Zollinger-Ellison syndrome.

Gastroenterology 61:655,1971.

109 Johnson L.R.

Gut hormones in growth of gastrointestinall mucosa.

In "Endocrinology of the Gut'. Ed. Chey and Brooks, published by Charles B. Slack Inc. N.J. pp. 163,1974.

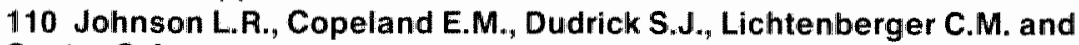
Castro G.A.

Structural and hormonal alterations in the gastrointestinal tract of parenterally fed rats.

Gastroenterology 68:1177,1975.

111 Neuburger P.H., Lewin M., Bonfils S.

Parietal and chief cell populations in four cases of the Zollinger-Ellison

syndrome.

Gastroenteralogy 63:937,1972.

112 Peterson $\mathrm{H}_{\text {, }}$, Myren J. and Liavag I.

Secretory response to secretin in a patient with diarrhea, and the Zollinger-

Ellison pattern of gastric secretion.

Gut 10:786,1969.

113 Dreiling O.A. and Greenstein A.

Pancreatic function in patients with the Zollinger-Ellison Syndrome.

Med.Chir.Dig. 1:1,1975.

114 Thompson J.C., Reeder D.D., Villar H.V. and Fender H.R.

Naturall history and experience with diagnosis and treatment of the Zollinger-

Ellison Syndrome.

Surg.Gyn. \& Obst. 140:721,1975.

115 Walsh $J_{.} H_{*}$, Debas H.I. and Grossman M.I.

Pure human "big gastrin": Immunochemical properties, disappearance half time and acid stimulating action in dogs.

J.Clin.Invest $54: 477,1974$.

116 Debas H.T., Walsh J.H. and Grossman M.I.

Pure human minigastrin: Secretory potency and disappearance rate

Gut 15:686,1974.

117 Straus E. \& Yalow R.S.

Studies on the distribution and degradation of heptadecapeptides, big and big-big gastrin.

Gastroenterology 66:936,1974.

118 Clendinnen B.G., Davidson W.O., Reeder D.D., Jackson B.M. and

Thompson J.C.

Renal uptake and excretion of gastrin in the dog

Surg.Gyn. \& Obstet. 132:1039,1971.

119 Booth R.A.O., Reeder D.D., Hjelmquist U.B., Brandt E. N ${ }_{n}$ and

Thompson J.C.

Renal inactivation of endogenous gastrin in dogs. 
Arch.Surg. 106:851,1973.

120 Davidson W.O., Springberg P.O., Falkinburg N.R.

Renal extraction and excretion of endogenous gastrin in the dog.

Gastroenterology 64:955, 1973 .

121 Walter R. and Bowman R.H.

Mechanism of inactivation of vasopressin and oxytocin by the isolated perfused rat kidney.

Endocrinology 92:189,1973.

122 Walsh J.H. $_{\text {. and Laster L. }}$

Enzymatic deamidation of the C-terminal tetrapeptide amide of gastrim by normalized tissues.

Biochem. Med. 8:432,1973.

123 Falcao H.A., Wesdorp R.I.C. and Fischer J.E.

Gastrin levels and gastrilc acid secretion in anephric patients and in patients with chronic and acute renal failure.

J.of Surg.Res. 18:809,1975.

124 Maxwell J.G., Moore J.C., Dixon J. and Stevens L.E.

Gastrin levels in anephric patients.

Surg.Forum 305, 1971.

125 Korman M.G., Laver M.C. and Hansky J.

Hypergastrinemia in chronic renal failure.

Br.Med.J. I:209,1972.

126 Shepard A.M.M., Stewart W.K. and Wormsley K.G.

Peptic ulceration in chronic renal failure.

Lancet 1357,1973.

127 Straus E., Gerson C.D. and Yalow R.S.\$

Hypersecretion of gastrin associated with the short bowell syndrome. Gastroenterology 66:175,1974.

128 Wickbom G., Landon J.H., Bushkin F.C. and McGuigan J.E.

Changes in canine gastric acid output and serum gastrin levels following massive small intestinal resection.

Gastroenterology 69(2):448,1975.

129 Coyle J.J., Varco R.L. and Buchwald $H$.

Gastric secretion and serum gastrin in human small bowel bypass.

Arch.Surg. 110(8), 1036, 1975.

130 Thompson J.C., Reeder D.D., Davidson W.D.

Studies on the metabolism of gastrin.

Nobel Symposium 16: Frontiers in Gastrointestinal Hormone Research,

Ed. Andersson, published by Almqvist \& Wiksell pp. 111,1973.

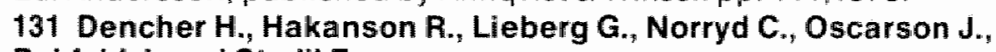

Rehfeld J. and Stadil F.

Gastrin in portal and peripheral venous blood after feeding in man

Gut 14:856,1973.

132 Wyllie J.H. Stagg B.H., Temperley J.M.

Inactivation of pentagastrin by the liver.

Br.J.Surg. 61:22,1974.

133 Dent R.I., Levine B., James J.H. and Fischer J.E.

Effects of isolated perfused canine lung and kidney on gastrin

heptadecapeptide.

Am.J.Physiol. 225:1038,1973. 


$$
48
$$




\section{Chapter III}

\section{Clinical aspects of gastrin}

In addition to its spectrum of physiologic functions, gastrin has been shown to be important in a number of clinical disorders. These can be subdivided under the headings of:

1. Increased amounts of circulating gastrin, either due to excessive production or diminished metabolism.

Syndromes which fall into this category are the Z.E.-syndrome, Multiple Endocrine Adenomatosis (MEA), retained antrum (1) and renall failure.

2. Increased amounts of circulating gastrin but with either absence or decreased responsiveness of the parietal cells. Conditions in this category are Type A autoimmune gastritis $(1,2)$ and after vagotomy $(3-6)$.

3. Normal amounts of circulating gastrin but increased responsiveness of the possible target-cells or organ as seen in achalasia of the esophagus $(1,7)$ and possibly in duodenal ulcer.

Within the limitations of this thesis, this chapter will deal briefly with the Z.E.syndrome as an introduction to the clinical study concerning plasma and parathyroid tumor tissue-gastrin in hyperparathyroidism. And in two following prospective studies the role of gastrin in peptic ulceration and in different forms of renal failure is studied.

\section{The Zollinger-Ellison Syndrome (Gastrinoma)}

The syndrome was first described by Zollinger and Ellison in 1955 (8) who suggested that the responsible secretaguogue was glucagon. The responsible secretaguogue was definitely characterized as gastrin by Gregory et all. in 1967 (9) although earllier work had suggested it (10). It is now known that the disorder results from prolonged hypergastrinemia due to release of gastrin from a tumor known as gastrinoma.

The tumor is a non-Beta islet cell tumor of the pancreas and belongs to the APUDOMAS or tumors arising from APUD-cells. The APUD-cells situated in the pancreas islets normally don't secrete gastrin, but the neoplastic changed APUD-cells or APUDOMAS seem to be able to synthetize and secrete other polypeptide hormones. However, gastrinomas can also arise from G-cells in duodenum and antrum.

Not uncommonly, ZE exists with other neuroendocrine tumors or APUDOMAS as part of the multiple endocrine adenomatosis. (MEA) in which adenomas of the parathyroids with hyperparathyroidism is the most common association (24, 25).

Associated endocrine adenomas in type $\mid M E A$ include along with the islet cell tumors of the pancreas, the anterior pituitary and parathyroids $(12,13,26)$.

The clinical syndrome consists of the following features $(11-15)$ although they are not all invariably present:

1. Fulminant or recurrent ulcer dilsease, often in atypical locations.

2. Massive hypersecretion of gastric acid. 
3. Diarthea.

4. Hypergastrinemia.

5. A non-Beta islet cell tumor of the pancreas (gastrinoma). This is occasionally found in the wall of the duodenum or stomach, or rarely in extragastrointestinal locations.

The importance of the Z.E.-syndrome lies in its seriousness. When untreated the mortality has been reported to be $78 \%(16)$, while a reported $30 \%$ of the diagnoses are still made in the autopsy room. Of nearly 1000 cases collected by Wilson (15), $59 \%$ of the tumors were malignant.

Although malignancy is a problem with late survival, early mortality is more often the result of excessive gastrin release, which has the following effects:

- an increasing rate of gastric acid secretion that gives rise to al most pure $\mathrm{HCL}$ with maximal secretion (17). In one study, ten Z.E. patients had a mean basal acid secretion of $44.3 \mathrm{mEq} / \mathrm{hr}$ compared with $2.3 \mathrm{mEq} / \mathrm{hr}$ in normals (18). The above changes are also accompanied by a reciprocal decrease in $\mathrm{Na}+$ and an increase in $\mathrm{K}+$ secretions (17).

- the wide spectrum of actions of gastrin is evident in gastrinoma patients in whom both basal and secretin stimulated pancreatic secretion are elevated as regards volume and bicarbonate secretions (18). Concomitantly, gastrin could also interfere with intestinal water and $\mathrm{Na}+$ absorption (19) as well as be responsible for the steatorrhea (20) perhaps associated with lack of activation of pancreatic lipase by acidified chyme. All features of the disease need not be present in each patient. Diarrhea may be the only symptom, but is absent in $30 \%$ (13) to $70 \%$ of the cases (12). Some patients lack the massive acid hypersecretion (21).

Occasionnally plasma gastrin is not elevated $(2,22)$, despite repeated determinations. Finally, some patients with the classical features of the syndrome have diffuse hyperplasia of the islets, but no tumor (14).

Zollinger and Ellison realized more than 20 years ago, that adequate treatment of the syndrome requires total gastrectomy ( 8 ) and this remains equally true today.

It is only in exceptional circumstances that a solitary non metastasing responsible adenoma is found $(2,8)$, and the rationale of removing the target organ is therefore obvious, as most of the mortality results from ulcer disease per se. Removal of the acid secreting stomach also removes the main cause for secretin release (acid in duodenum). Secretin is a known releaser of gastrin from gastrinomas (27), and this may cause a vicious circle. 


\section{Plasma and Parathyroid Tumor Tissues Gastrin and Hyperparathyroidism}

Hyperparathyroidism has been associated with an increased incidence of peptic ulceration $(25,28,29)$, increased gastric acid secretion $(25,29,30)$, and increased plasma gastrin levels (25). A relationship between these changes, increased serum calcium levels, and the increased incidence of peptic ulceration has been suggested, especially since increased plasma gastrin levels (25), serum calcium levels (29), and gastric acid secretion $(25,29,30)$ decrease after parathyroidectomy.

We have previously suggested that the fall in plasma gastrin after parathyroidectomy may suggest an extragastric source of gastrin (25). Others (31) using immunofluorescent studies have suggested that the parathyroid adenomas themselves might be the source of this gastrin. Friesen (32) in reviewing the clinical manifestations of multiple endocrine adenomatosis (MEA) has pointed out the genetic and embryologic similarities of the endocrine cells that may result in the production of many different hormones by the same tumor. Parathyroid tumors have been found to secrete parathyroid hormone and possibly adrenocorticotropic hormone (ACTH) (33).

To our knowledge, gastrin as measured by radioimmunoassay has not been recovered from a parathyroid adenoma. The purpose of this study was to determine if parathyroid adenomas might be the source of this gastrin (31) and to confirm the relation of serum calcium and plasma gastrin levels before and after parathyroidectomy.

\section{Materials and methods}

Fifteen patients with primary hyperparathyroidism before and after parathyroidectomy were studied prospectively. There were seven women (average age 51 years, range 41 to 71 years) and eight men (average age 55 years, range 48 to 71 years). Four patients complained of epigastric symptoms related to food and three had radiologically proven duodenal uilceration, an incidence in this small group of $20 \%$, similar to previous experience (25).

In each patient, serum calcium and plasma gastrin levels were determined simultaneously on at least two occasions before and after parathyroidectomy. Parathyroid tumor was obtained in the operating room in all fifteen patients. A portion of the parathyroid tumor was immediately frozen and several sections saved for formalin fixation and examination by light microscopy. The remainder of the frozen parathyroid tumor was used for determination of tissue gastrin content.

For this purpose the tumor tissue was homogenized in $2 \mathrm{ml}$ of $0.02 \mathrm{M}$ barbital buffer, $\mathrm{pH} 8.4$, after which it was rapidly frozen and thawed ten times to release all bound hormone and reduce the non-specific binding. Gastrin radioimmunoassay was performed using antibodies that had been produced in rabbits after repeated immunization with synthetic humanlike gastrin (SHG 2-17) conjugated to bovine serum albumin as previously described (25). Dextran-coated charcoal was used to separate labeled gastrin bound to antibody from free labeled gastrin. Each sample was assayed in triplicate on at least two separate assay determinations. 
In fourteen patients the diagnosis of primary hyperparathyroidism was confirmed pathologically by demonstrating a parathyroid adenoma in the absence of hyperplasia in at least one other gland. There was no demonstrable cause for the parathyroid hyperplasia found in one patient, and he was considered to have primary hyperplasia.

Statistical analysis of differences was by use of correlated and uncorrelated Student $t$ test. Data are given as mean + standlard of mean and $p \quad 0.05$ is considered significant.

\section{Results}

The mean basal plasma gastrin level before operation was $146 \pm 46 \mathrm{pg} / \mathrm{ml}$, significantly higher than a control group matched for age $(26 \pm 4 \mathrm{pg} / \mathrm{ml})$, and which decreased to a mean of $86 \pm 22 \mathrm{pg} / \mathrm{ml}$ postoperatively (correlated t-test. $p<0.30$ ) (Figure 17). One patient without a duodenal ulcer or symptoms had pre-and postoperative plasma gastrin values in the range characteristic of Zollinger-Ellison syndrome $(>4,000 \mathrm{pg} / \mathrm{ml})$ and was excluded, since inclusion would have unduly biased the mean. As can be seen in Figure 18, not all plasma gastrin levels decreased after operation, in contrast to calcium levels. The mean preoperative serum calcium level was increased to $12.1 \pm 0.03 \mathrm{mg} / 100 \mathrm{ml}$ and decreased to $9.1 \pm 0.04 \mathrm{mg} / 100 \mathrm{~m} /$ postoperatively $(p<0.02)$. (Figure 17)

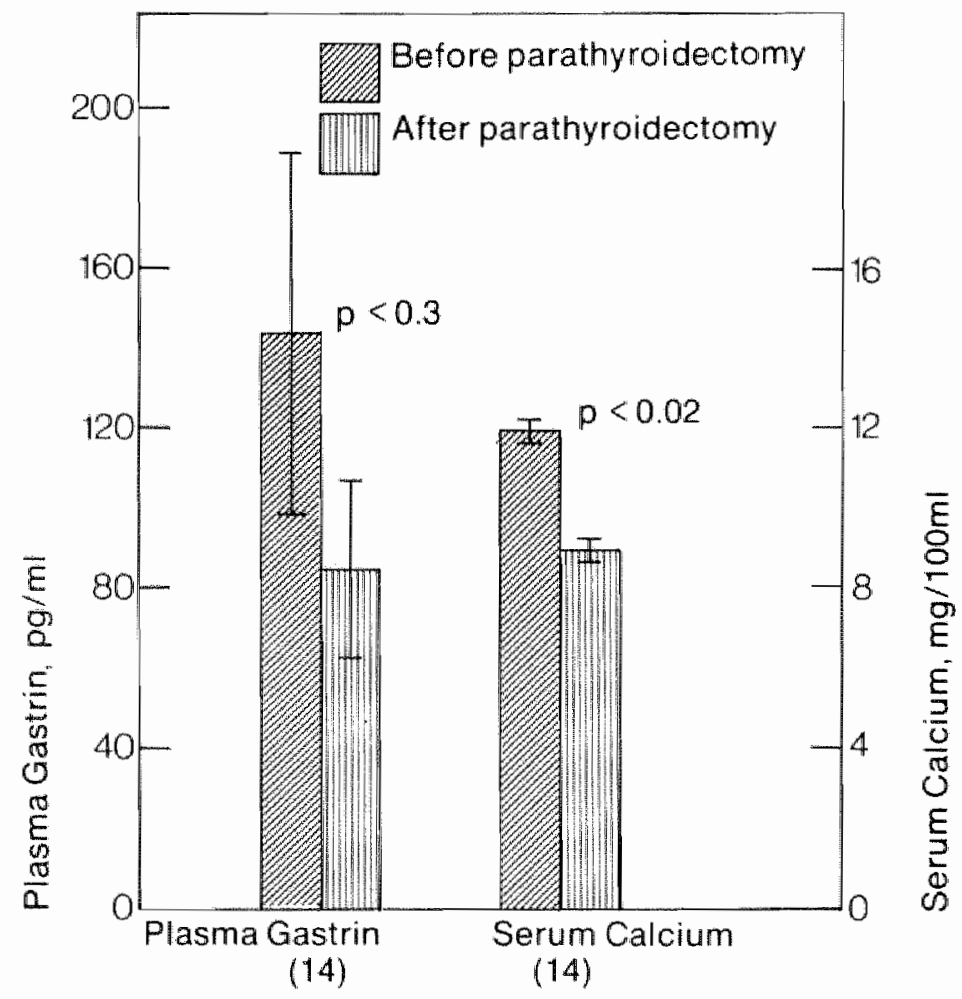

Figure 17. Mean Galcium and Gastrin hevels before and after parathyroidectomy. 
Parathyroid tumor tissue of the lifteen patients was assayed for gastrin content by the radioimmunoassay technique and no detectable amounts of gastrin could be recovered from any tumor. Of the three patients with proven duodenal ulceration, only one patient had high preoperative plasma gastrin values $(930$ and $780 \mathrm{pg} / \mathrm{ml})$, which decreased after parathyroidectomy $(330$. $450,280 \mathrm{pg} / \mathrm{ml}$ ), whereas the plasma gastrin levels in all the other patients were within normal iimits.

Furthermore, no positive correlation could be found between plasma gastrin and serum calcium levels before and after operation.

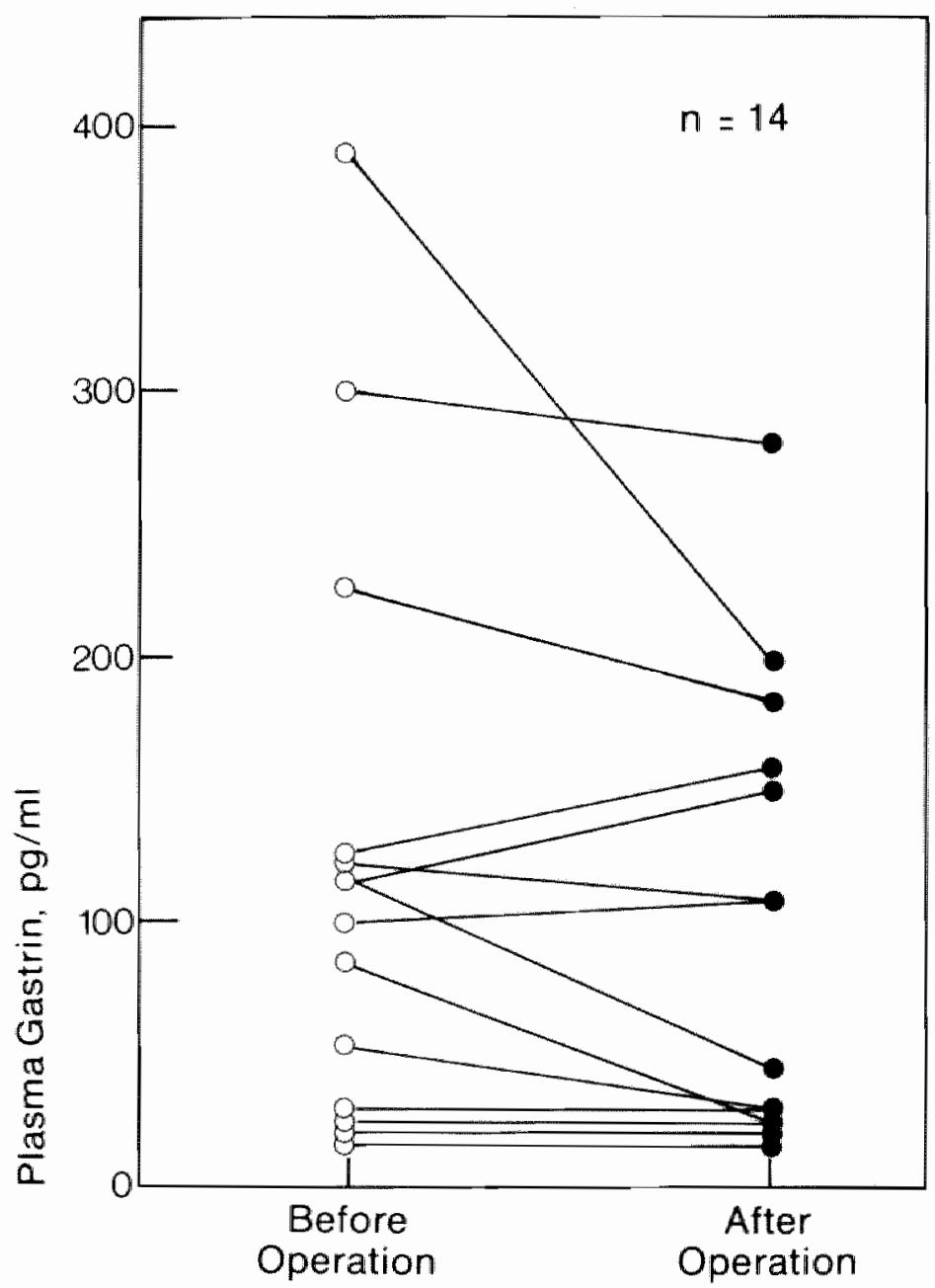




\section{Discussion}

The relationship between hyperparathyroidism and peptic ulceration has been well documented, but its exact causation remains unclear $(28,34,35)$, possibly because the precise etiologic feature of uncomplicated peptic ulcer disease still remains an enigma.

Most reported clinical studies suggest a primary relationship between serum calcium and plasma gastrin levels resulting in an increased gastric acid secretion $(25,29,31,36)$, whereas the possible secondary role of excessive parathyroid hormone still remains uncertain $(25,36,37)$. It has been shown that hypercalcemia induced by intravenous calcium infusions stimulates gastric acid secretion and increases plasma gastrin levels in normal subjects, in patients with duodenal ulcer, and in patients with the Zollinger-Ellison syndrome $(38,39)$. Similarly, it has been shown that intragastric calcium can act both to release gastrin under some circumstances $(37,40)$ and to stimulate the parietal cell directly in healthy subjects and in patients with duodenal ulcer (37).

However, all those clinical studies concern rapidly changing serum calcium levels, in contrast to the persistently elevated calcium values seen in patients with hyperparathyroidism, in whom adaptation to the hypercalcemic state might occur.

The finding in this and other reported series $(25,31,38)$ that only 50 per cent of the patients with hyperparathyroidism show elevated preoperative plasma gastrin values, whereas the rest are within normallimits, might indeed suggest that in some cases of primary hyperparathyroidism there is a certain adaptation to the elevated serum calcium levels.

Stremple and Watson (31) suggested that the parathyroid adenomas might be able to produce gastrin and give rise to increased gastric acid secretion, as in the Zollinger-Ellison syndrome. As a rationale, they pointed out that the parathyroid hormone- and gastrin-secreting cells share a common embryologic background and belong to the APUD-cells (41). Most of the lumors arising from these cells ("APUDOMAS") seem to be able to secrete more than one hormone as described for some islet cell tumors $(42,43)$. However, the results reported herein do not support this concept in the patients with primary hyperparathyroidism and ellevated plasma gastrin levels, since we were unable to recover any gastrin in fourteen parathyroid adenomas or in one patient with parathyroid hyperplasia. lif there is an extragastric source of gastrin in patients with hyperparathyroidism, it does not arise in the parathyroid adenomas. 


\section{Gastrin and Acid Secretion in Peptic Ulceration}

Gastrin plays a crucial role in gastric-acid secretion in man, but its rolle in the pathogenesis of peptic ulceration is still uncertain. Onlly in patients with a gastrinoma, it has been shown that there is a direct relationship between the very high plasma-gastrin levels, the extremely elevated rates of gastric-acid secretion, and severe upper-gastrointestinal ulcer disease $(8,14)$. This represents, for the most part, extra-antral gastrin released from a tumor, and no such relation has been shown in peptic ulceration.

While the few reports of basal plasma-gastrin levels in patients with a gastric ulcer indicate higher levels than in normal subjects $(44,45)$, there still exists considerable controversy about basal plasma-gastrin levels in patients with a duodenal ulcer. In this group of patients, basal plasma-gastrin in different reports has ranged from low (46) to normal $(45,47,48)$, high (49-51) and very high (52) levells. The majority of patients with a duodenal ulcer have a basal intragastric pH of less than two. It might be expected, therefore, that patients with duodenal ulcer would have low basal plasma-gastrin levels, since acid inhibition is the most potent inhibiting influence on gastrin release. The present study examines the relation between basal plasma-gastrin levels, basal intragastric $\mathrm{pH}$, and basal and stimulated gastric-acid secretion in patients with gastric and duodenal ulceration. The findings imply some autonomy of gastrin release in duodenal ulcer disease.

\section{Patients, materials and methods}

101 patients with a duodenal ulcer and 31 patients with a gastric ulcer were studied. The duodenal ulcer patients consisted of 23 women (mean age 50 years, range $31-75$ ) and 78 men (mean age 51 years, range $17-77$ ), while the gastric ullcer group consisted of 15 women (mean age 51 years, range 21-68) and 16 men (mean age 52 years, range $22-74$ ). The diagnosis for all patients included in this study was established by multiple upper-gastrointestinal $X$-rays, and, in most, by endoscopic examination. The control group consisted of 30 persons, 11 women and 19 men (mean age 54 years, range 30-72). They included laboratory workers and hospital in-patients, all without recognised gastrointestimal disease, and matched for age distribution. In the present study, patients over 80 years of age and those with proven atrophy of the gastric mucosa and achlorhydria were excluded.

Gastric secretion studies were carried out on all the duodenal and gastric ulcer patients by a single technician, long experienced in acid studies. Following an overnight fast, a no. 16 or no. 18 nasogastric tube was passed into the stomach. Overnight gastric contents were manually aspirated and discarded, and a basal one-hour collection of gastric contents abtained (BAO) by intermittent pump and hand aspiration every fifteen minutes. The maximum acid secretion was then determined by collection of four consecutive fifteen-minute aspirates of gastric juice by intermittent pump and manual aspiration after subcutaneous administration of either histamine $0.04 \mathrm{mg}$ per $\mathrm{kg}$ of bodyweight or pentagastrin ("Peptavlon" "I.C.I.) $0.006 \mathrm{mg}$ per kg of bodyweight. Patients stimulated with histamine received $50 \mathrm{mg}$ of diphenhydramine hydrochloride ("Benadryl") subcutaneously thirty minutes before histamine administration. The maximum 
acid secretion (P.A.O.) was expressed as the peak thirty-minutes output multiplied by two in milliequivalents per hour. Prior to insertion of the gastric tube, fasting venous blood was obtained from each patient; plasma was separated rapidly by centrifugation and stored at $-20^{\circ}$ before radioimmunoassay.

After an overnight fast, fasting blood was also obtained from 30 control subjects, separated, and stored at $-20^{\circ} \mathrm{C}$.

Gastrin radioimmunoassay was performed using antibodies that had been produced in rabbits after repeated immunisation with synthetic human gastrin I (SHG 2-17) conjugated to bovine serum-albumin as previously described (25).

Dextran-coated charchoal was used to separate labeled gastrin bound to antibody from free ${ }^{125}$ gastrin. Each sample was assayed in triplicate in at least two separate assay determinations.

Statistical method - Plasma gastrin levels were submitted to group comparisons by means of the Student t test.

\section{Results}

\section{Gastric-acid secretion}

The mean B.A.O. was $5.3 \pm 0.4 \mathrm{mEq} / \mathrm{hr}$ in the duodenal ulcer group and $2.7 \pm 0.4 \mathrm{mEq} / \mathrm{hr}$ in the gastric ulcer patients $(p<0.001)$. The mean P.A.O. Was $34.0 \pm 1.3 \mathrm{mEq} / \mathrm{hr}$ in the duodenal ulcer group and $19.8 \pm 2.0 \mathrm{mEq} / \mathrm{hr}$ in the gastric ulcer patients $(\mathrm{p}<0.001)$. The mean basal intragastric $\mathrm{pH}$ was, as expected, significantly lower $(p<0.02)$ in the duodenal ulcer group $(1.8 \pm 0.06)$ than in the gastric ulcer patients $(2.6 \pm 0.01)$.

\section{Plasma-gastrin}

The mean plasma-gastrin (P.G.j level in the 101 patients with duodenal ulcer was $61 \pm 7 \mathrm{pg} / \mathrm{ml}$, which was only slightly higher than in the 30 control patients (54 $\pm 9 \mathrm{pg} / \mathrm{ml}, \mathrm{p}<0.2$ ). However, the mean basal P.G. in the gastric ulcer group was significantly higher than in the control group $(93 \pm 17 \mathrm{pg} / \mathrm{ml}, \mathrm{p}<0.05)$.

When we compare the mean basal P.G. of the two groups with their mean basal intragastric $\mathrm{pH}$ and B.A.O. (Table II), a direct inverse relationship seems to

Table II:

\begin{tabular}{|c|c|c|c|c|}
\hline Group & $\begin{array}{l}\text { No. of } \\
\text { patients }\end{array}$ & $\begin{array}{l}\text { Mean } \\
\text { basal } \\
\text { P.G. } \\
\text { (pg./ml.) }\end{array}$ & $\begin{array}{l}\text { Mean basal } \\
\text { Intragastric } \\
\text { pH }\end{array}$ & $\begin{array}{l}\text { Mean } \\
\text { B.A.O. } \\
\text { (mEq/hr) }\end{array}$ \\
\hline Duodenal ullcer & 101 & $61+7$ & $1.8 \pm 0.06$ & $5.4 \pm 0.4$ \\
\hline Gastric ulcer & 31 & $93 \pm 17$ & $2.6 \pm 0.01$ & $2.7 \pm 0.7$ \\
\hline
\end{tabular}


exist between basal P.G. on the one hand, and basal intragastric pH and B.A.O. on the other, a low $\mathrm{pH}$ reflecting greater acid inhibition of gastrin release. However, when the 132 patients are grouped according to their basal intragastric pH and their basal P.G. is compared, the inverse relationship disappears (figure 19), and we find no significant differences between the different groups. Also, when the gastric and duodenal ulcer patients are compared separately, no inverse relationship can be found, although the number of patients with a pH greater than 4.5 is small.

\section{Combined duodenal gastric ulcer patients}

Duodenall ulcer patients

Castric ulcer patients

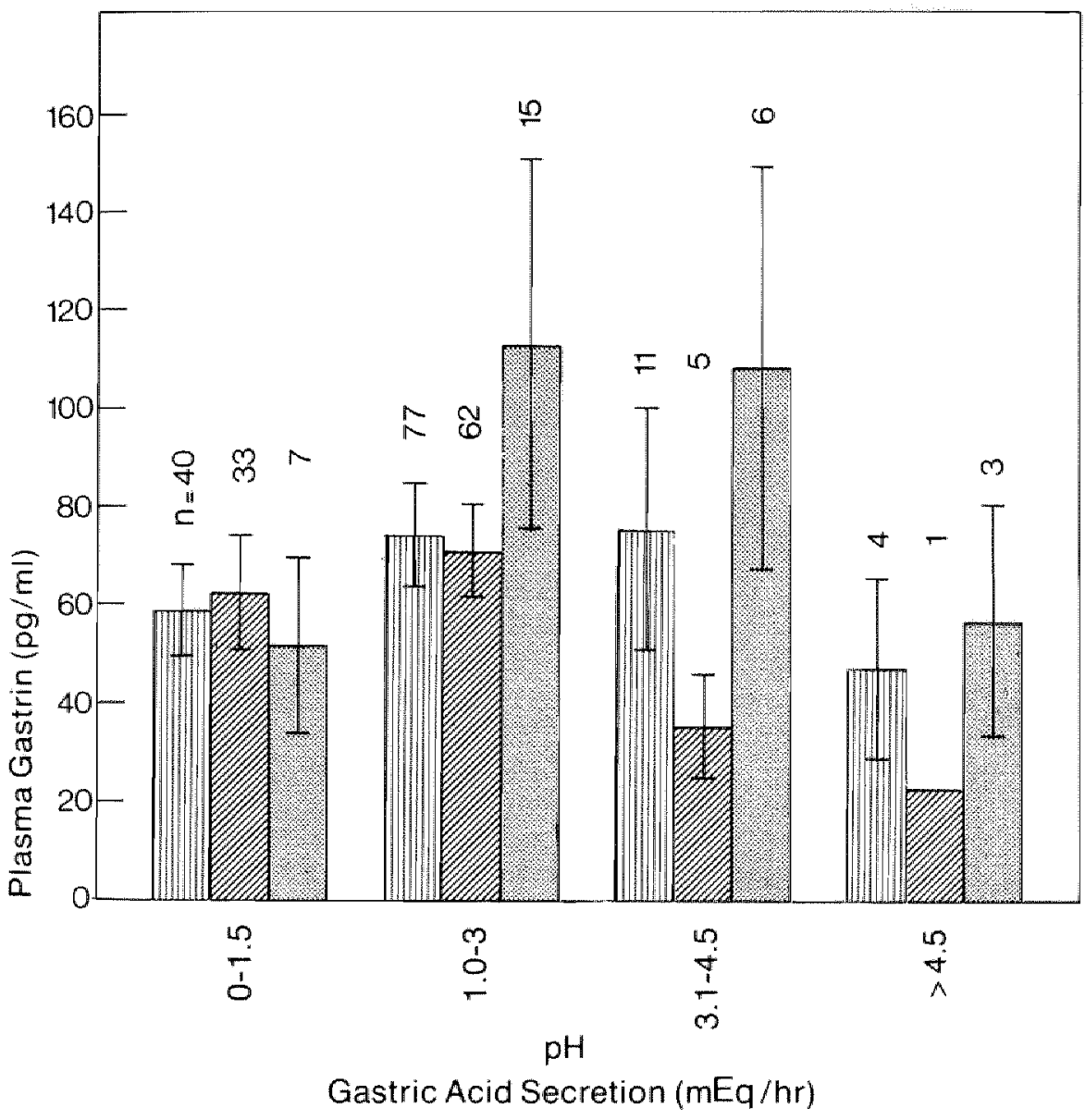




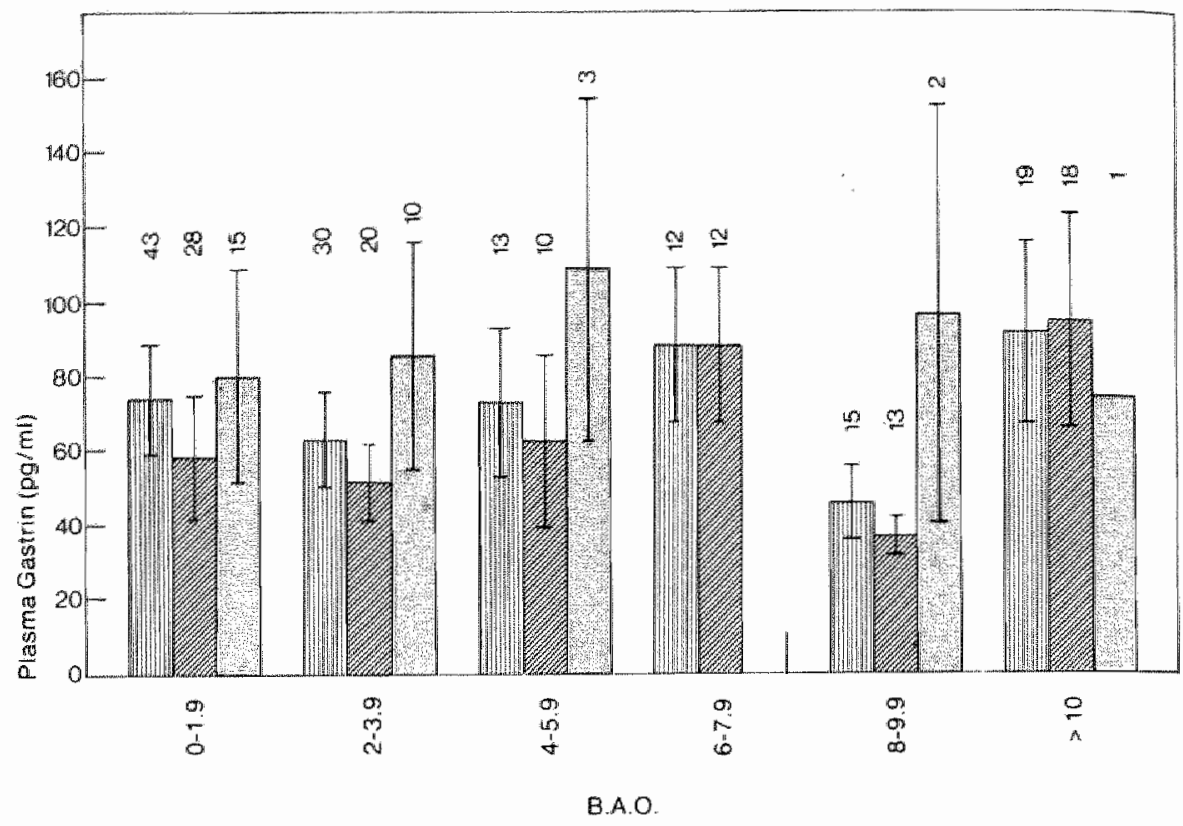

Gastric Acid Secretion (mEq/hr)

Figure 20. Mean besal plasma gastrintevels (1 S.E.M.) versus basal acid secretion (BAO) for the total of 132 patients and for the gastric and duodenal ulicer patients separately.

When we grouped the patients according to their rates of basal acid secretion and compared their basal P.G. (figure 20) there was no significant difference between the groups and no inverse relationship was shown, whether all cases were grouped together or the cases were separated in those with a duodenal or gastric ulcer. When the patients were grouped according to their rates of P.A.O. and their basal P.G. was compared in the same manner, no relationship could be demonstrated (figure 21).

\section{Discussion}

Gastric acid has been implicated in the pathogenesis of peptic ulceration and. although the dictum "no acid, no ulcer" is still largely true, the precise role of gastric acid and its relation to other factors have not been defined. Even less is known about the role of gastrin, the most potent stimulator of gastric-acid secretion, in the pathogenesis of peptic ulcer disease.

Only in the Zollinger-Ellison syndrome is there a direct relationship between very high basal gastrin levels, increased rates of gastric-acid secretion, and upper-gastrointestinal ulcer disease.

Except for this syndrome, a low basal intragastric $\mathrm{pH}$ is thought to effectively inhibit antral gastrin release.

Hansky and Korman (53) have reported a direct inverse relationship between the mean basal P.G. and mean basal intragastric $\mathrm{pH}$ in duodenal and gastric ulcer patients as well as in a group of controls. When all patients are grouped 


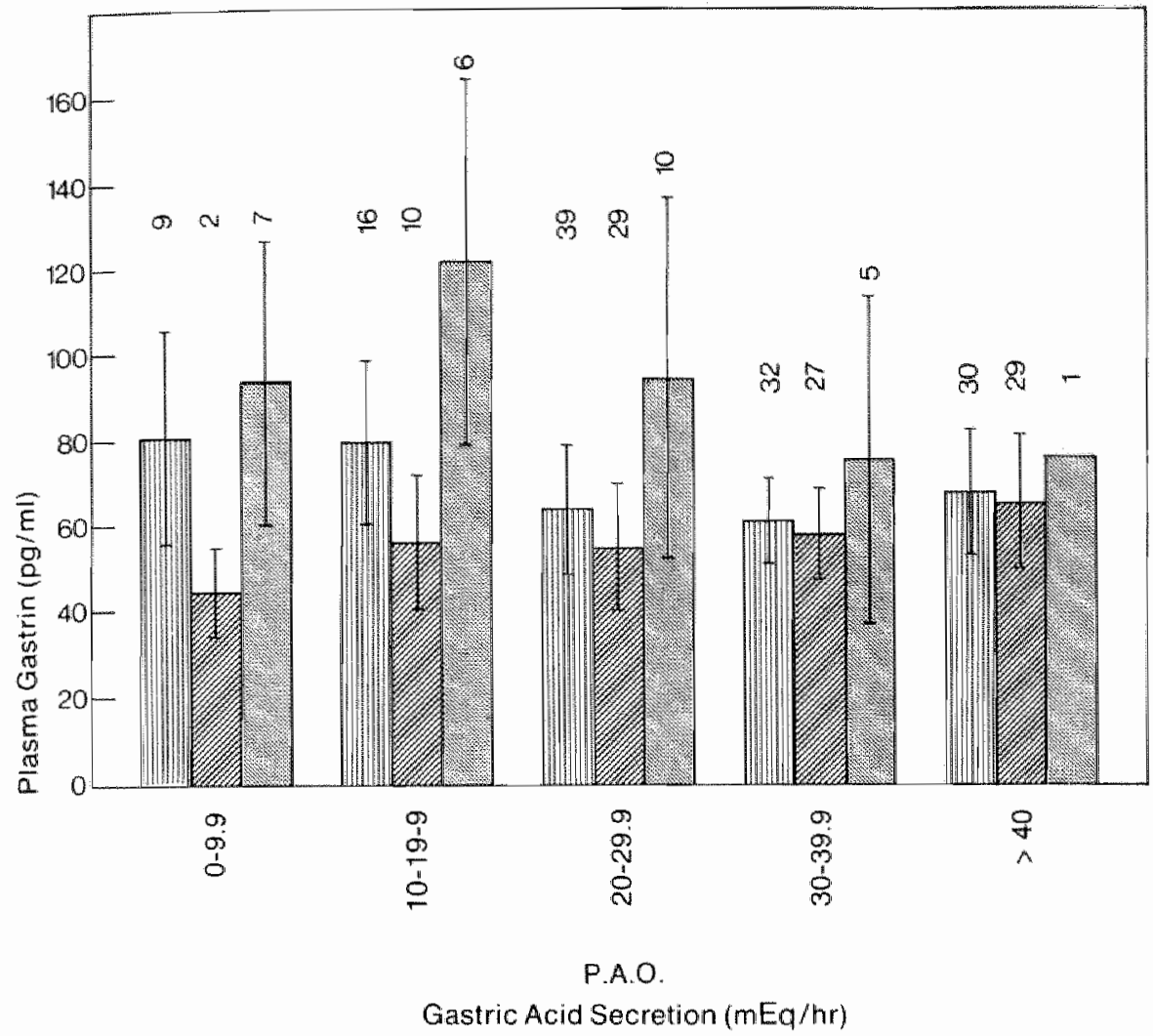

Figure 21. Mean basal plasma gastrin levels ( \pm S. E.M.) wersus maximum stimulated gastric acid ( $P$ AO) secretion for the total of 132 patients and for the gastric and duodenal ulcer patients separately.

according to whether they have either duodenal or gastric ulcer, this relationship seems to exist (table $\| I$ ), but when they are grouped according to their basal intragastric $\mathrm{pH}$ as a function of basal P.G. (figure 19) we cannot demonstrate this inverse relationship in the sense of increasing P.G. levels with an increasing $\mathrm{pH}$. Also, when the patients in the two groups were grouped according to their different rates of B.A.O. (figure 20), we were not able to demonstrate the inverse relationship reported by Trudeau and McGuigan in their heterogenous group of patients (54). Similarly Gedde-Dahl (55) was unable to show an inverse relationship between basal P.G. and B.A.O. in a total of 298 patients with widely differing lesions.

The fact that we did not find an inverse relationship between basal P.G. and B.A.O. could imply some autonomy of gastrin release in peptic ulceration, a defective feedback mechanism, or a major contribution of extra-antrall gastrin to basal circulatory gastrin.

There is some support for the autonomy of gastrin release in the few reports of P.G. levels measured by bioassay in plasma of duodenal ulcer patients, which were significantly higher than in normal subjects (56) and furthermore in the 
Table ll:

Basal plasma gastrin levels in normals and in duodenal ulcer and gastric ulcer patients

\begin{tabular}{|c|c|c|c|c|c|c|}
\hline \multirow[t]{2}{*}{ Source } & \multicolumn{2}{|c|}{ Normals } & \multicolumn{2}{|c|}{ Duodenal ulcer } & \multicolumn{2}{|c|}{ Gastric ulcer } \\
\hline & No. & $\begin{array}{l}\text { Gastrin } \\
\mathrm{pg} / \mathrm{ml}\end{array}$ & No. & $\begin{array}{l}\text { Gastrin } \\
\mathrm{pg} / \mathrm{ml}\end{array}$ & No. & $\begin{array}{l}\text { Gastrin } \\
\mathrm{pg} / \mathrm{ml}\end{array}$ \\
\hline \multicolumn{7}{|l|}{ Byrnes et al. } \\
\hline 1970 & 41 & 400 & 27 & 1300 & 12 & 400 \\
\hline \multicolumn{7}{|l|}{ Stadil and } \\
\hline Rehfeld 1971 & 20 & 93 & 12 & 76 & - & \\
\hline \multicolumn{7}{|l|}{ Trudeau and } \\
\hline McGuigan, 1972 & 10 & $71 \pm 9.4$ & 22 & $76 \pm 7$ & - & \\
\hline \multicolumn{7}{|l|}{ Ganguli and } \\
\hline Hunter, 1972 & 113 & $105 \pm 7$ & 27 & $91 \pm 6$ & 14 & $285 \pm 31$ \\
\hline \multicolumn{7}{|l|}{ Stern and } \\
\hline Walsh, 1972 & 8 & $54+8$ & 8 & $65 \pm 7$ & $\longrightarrow$ & \\
\hline \multicolumn{7}{|l|}{ Hansky and } \\
\hline Korman, 1973 & 252 & $36 \pm 3.7$ & 206 & $13 \pm 0.8$ & 75 & $99 \pm 6$ \\
\hline \multicolumn{7}{|l|}{ Wesdorp and } \\
\hline Fischer, 1974 & 30 & $54 \pm 9$ & 101 & $61 \pm 7$ & 31 & $93+17$ \\
\hline
\end{tabular}

finding of antral G-cell hyperplasia in some patients with peptic ulceration and lhypergastrinemia without a gastrinoma (57).

Although there is little question that antral secretion of gastrin is inhibited by a low intragastric $\mathrm{pH}$, one wonders how much this should affect circultating fasting or basal gastrin levels, most of which presumably are not antral in origin (58). It has been shown that the quantities of gastrin extracted from human duodenal mucosa are nearly equal to those obtained from the antrum (59), and that after a Billroth I gastrectomy without vagotomy there is no decrease in basal P.G. levels (60) suggesting a major contribution of duodenal gastrin to basal P.G. levels.

However, little is known about the exact mechanism of release and inhibition of duodenal gastrin in man and it is not known what effect, if any, basal intragastric $\mathrm{pH}$ and B.A.O. has on the release of duodenal gastrin. Although it has been shown by us that acidification inhibited release of duodenal gastrin by acetylcholine in the dog (61).

Furthermore, McGuigan and Herbst have shown, by using antibodies which tended to differentiate "big" gastrin and the heptadecapeptide form of gastrin, that circulatory basal gastrin is largely extra-antral, while post-prandial P.G. is mostly antral in origin (62).

In gastric ulcer patients we find, as in a few previous reports $(44,45)$ higher basal P.G. levels than in normais. Diminished inhibition of gastrin release by gastric acid can account only partly for these higher basal levels since we did 
not find an inverse relationship between basal P.G. and B.A.O. in these patients either (the numbers are small).

The greatest problem in evaluating and comparing gastrin levels is that the different antisera, even in the same laboratory $(62,63)$ measure different forms of circulating gastrin, which can explain the variability in results between laboratories.

In the present investigation the apparent absence of inverse relationship between basal P.G. and B.A.O. may also be due to the fact that we measure a different circulating form of gastrin.

So long as the form of gastrin predominantly circulating in peptic ulcer disease, and the molecular species of gastrin measured by one particular immunoassay. are unknown it is difficult to draw conclusions about a possible role of gastrin in the pathogenesis of peptic ulceration. The results in this study suggest that the duodenum may make a major contribution to basal circulating gastrin or that there may be some autonomy of gastrin release in duodenal ulcer patients, since an inverse relationship between basal P.G. levels and B.A.O. or basal intragastric $\mathrm{pH}$ could not be demonstrated. Alternatively, the data may be interpreted as showing that basal acid secretion neither determines nor is determined by basal P.G. 


\section{Gastrin and gastric acid secretion in renal failure}

The kidneys are well established as a major site of accumulation and degradation of many polypeptide hormones (64-65) including gastrin (67). Earlier reports have shown that approximately $40 \%$ of exogenous synthetic human gastrin (68) and $30 \%$ of stimulated endogenous dog gastrin $(69,70)$ is extracted from the renal artery plasma in a single pass through the kidney. As very little gastrin appears in the urine (71), the peptide is presumably metabolized within the kidney. Further proof is that an enzymatic activity has been described in perfused rat kidney that catalyzed cleavage of the $\mathrm{C}$-terminal glycinamide form oxytocin and vasopressin (72). while another activity was found in rat kidney homogenates that cleaved the $\mathrm{C}$-terminal dipeptide amide Asp Phe- $\mathrm{NH}_{2}$ from gastrin tetrapeptide (73).

Furthermore clinical studies have demonstrated increased plasma gastrin (PG) llevels in nephrectomized patients (74), and in patients with severe renal disease $(75,76)$. And although it is known that there is a high incidence of gastritis and upper gastrointestinal bleeding, as well as duodenal ulceration in patients with renal failure, comparatively little attention has been paid to gastric acid secretion in these patients, as it has been assumed that the formation of gastric ammonia decreased titratable acidity.

However, in the last few years there have been reports of elevated basal and stimulated gastric acid secretion in uremic patients $(77,78)$. This raises the possibility that some of the gastro-intestinal bleeding and ulceration seen in uremia may in fact be due to increased gastric acid secretion caused in turn by elevated PG levels, secondary to inadequate renal activation. To study this possible correlation, we measured basal PG levels and basal and stimulated gastric acid secretion in three groups of renal failure patients: patients with acute renal failure, chronic renal failure and anephric patients awaiting transplantation.

\section{Patients and methods}

The three groups of patients consisted of 10 anephric patients awaiting cadaver donor transplantation, 15 patients with chronic renal failure (CRF) and 30 patients with acute renal failure (ARF).

The mean age of the anephric, CRF and ARF patients was respectively 34 years, 49 years, and 52 years, whille the mean age of the 15 healthy control persons. was 42 years. They included laboratory workers and hospitalized patients, all without recognized gastrointestinal disease.

Multiple fasting PG samples were obtained from the 10 anephric patients before transplantation and from eight transplanted patients daily after kidney transplantation.

From 15 patients on hemodialysis (CRF) fasting PG samples were obtained just before and directly after hemodialysis. In the group of 30 patients with ARF daily PG samples were obtained until kidney function returned to normal. The plasma samples were stored at $-20^{\circ} \mathrm{C}$ before radioimmunoassay. Serum creatinine, blood urea nitrogen, and urinary outputs were recorded from all patients on the same day as the PG samples were taken.

Gastrin radioimmunoassay was performed using antibodies that had been produced in rabbits after repeated immunisation with synthetic human gastrin (SHG 2-17) conjugated to bovine serum albumin as previously described (25). Dextran-coated charcoal was used to separate labeled gastrin bound to 
antibody from free 125 -gastrin. Each sample was assayed in triplicate on at least two separate occasions.

Gastric acid secretion studies were carried out in seven anephric patients, ten patients with CRF, and in ten ARF patients during their anuric period. After an overnight fast, a no. 16 or no. 18 nasogastric tube was passed into the stomach, overnight gastric contents were manually aspirated and discarded, and a basal one hour collection of gastric contents obtained (BAO) by intermittent pump and hand aspiration every 15 minutes.

The maximum acid secretion was then determined by collection of four consecutive 15 -minute aspirates of gastric juice by intermittent pump and manual aspiration.

The maximum acid secretion was then determined by collection of four consecutive 15-minute aspirates of gastric juice by intermittent pump and manual aspiration after subcutaneous injection of Peptavlon (ICl) $0.006 \mathrm{mg} / \mathrm{kg}$ of body weight. The volume of each sample of gastric juice was noted and the total acidity measured by titration with $0.1 \mathrm{~N} \mathrm{NaOH}$ and $\mathrm{pH}$ of 7 ( $\mathrm{pH}-$ meter-25. Radiometer, Copenhagen). The maximum acid secretion (PAO) was expressed as the peak 30-minute output multiplied by two in $\mathrm{mEq} / \mathrm{hr}$.

Hemodialysis was carried out in all the anephric and CRF patients as well as in some patients with ARF.

Statistical comparison of the results involved the calculation of mean values and standard errors of the mean. Statistical analysis of differences was by use of correlated and uncorrelated Student t test. In the text, data are given as a mean \pm SEM and where the word significantly is used it indicates a calculated p value of less than 0.05 .

\section{Results}

The mean basal PG in the 10 anephric patients was $176 \pm 28 \mathrm{pg} / \mathrm{ml}$, significantIy higher $(p<0.001)$ than in the 15 control persons $(26 \pm 4 \mathrm{pg} / \mathrm{ml})$. This mean value decreased significantly $(p<0.01)$ after kidney transplantation in 8 patients to $16 \pm 3 \mathrm{pg} / \mathrm{ml}$ at dischargle (figure 22 ).

As can be seen in figure 23 , one of the transplanted patients, a 32 year old male, remained anuric immediately after renal transplantation, during which period also the PG levels remained elevated. They only decreased and returned to normal when the kidney function improved and BUN and creatinine returned to mormal. Another interesting finding was in 2 other transplanted patients where PG levels decreased dramatically after transplantation, but started to rise again when the transplanted kidney was being rejected (figure 24). In both cases, the PG levels tended to rise earlier than the BUN and serum creatinine. In the 15 patients with CRF, the mean PG was 89 - $19 \mathrm{pg} / \mathrm{ml}$ higher $(\mathrm{p}<0.001)$ than the control group (figure 25).

The mean PG in 25 patients with ARF was $149 \pm 40 \mathrm{pg} / \mathrm{ml}(\mathrm{p}<0.02)$ while five patients at some time during their acute renal failure had $P G$ levels in the Zollinger-Ellison syndrome range $(11000-5000 \mathrm{pg} / \mathrm{ml})$ which would have unduly biased the mean value. It is interesting that only 15 of the 30 patients with ARF $(50 \%)$ and 8 of the 15 patients with CRF $(55 \%)$ showed elevated PG values, while all the anephric patients had elevated $\mathrm{PG}$ levels. This would seem to indicate that only certain pathologic changes involve the gastrin inactivating mechanism. Again in the ARF group, PG levels decreased to normal as kidney function improved.

At variance with other reports, hemodialysis did decrease PG levels in 15 


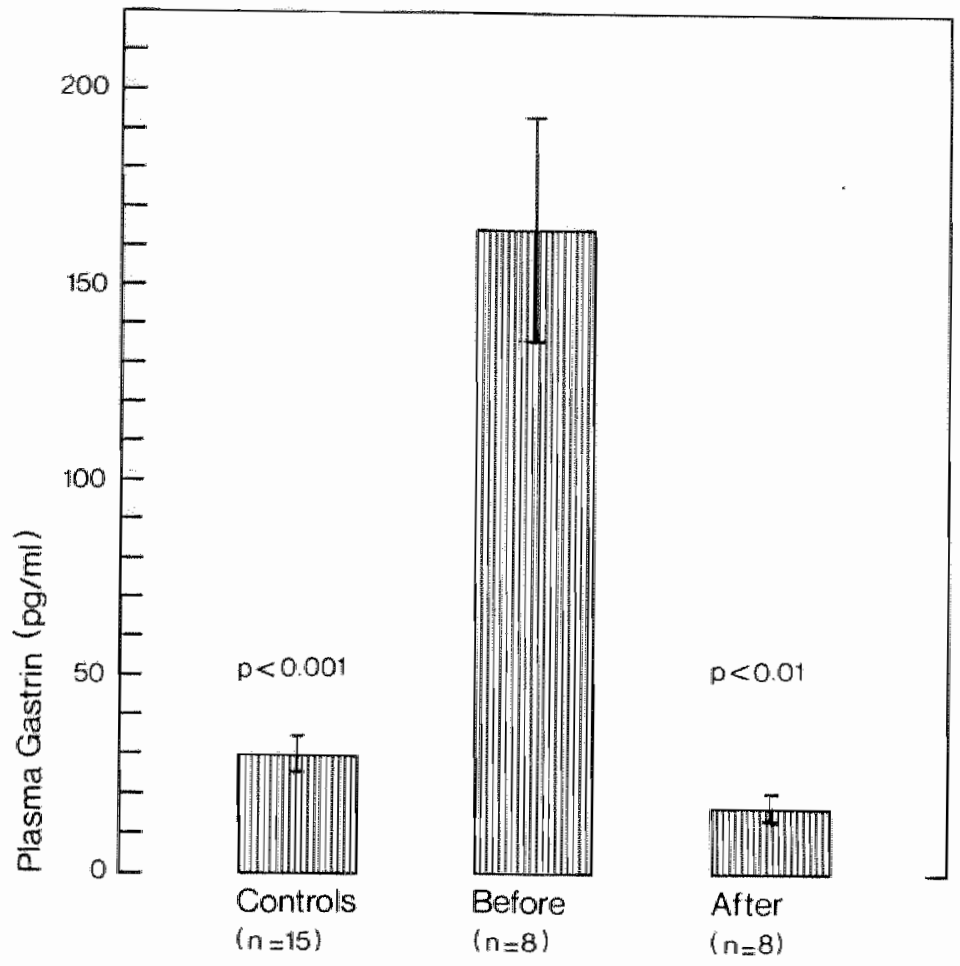

Figure 22. Mean plasma gastrin levels (土 S.E.M.) before and ater kidney transplantation in eight anephric patients.

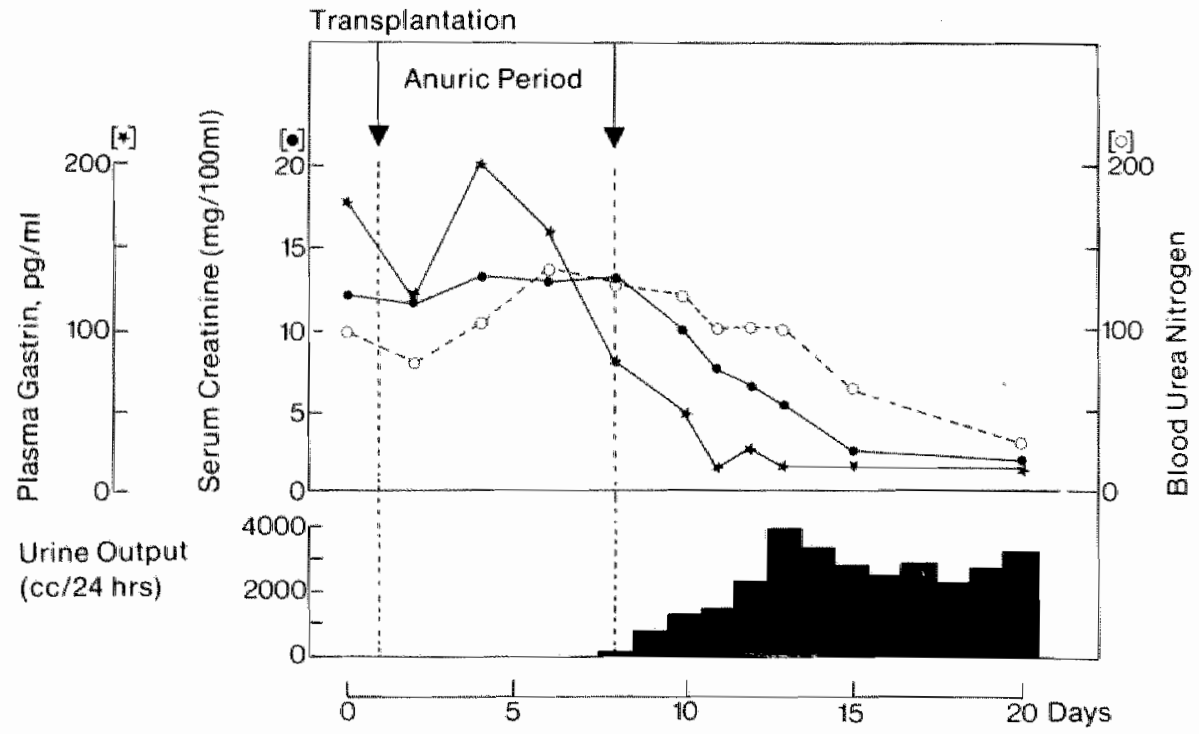

Figure 23. Plasma gastrin, serum creathine. blood urea nitrogen, and urinary wolume in an anephric patient (man, 32 yr) before and after kidney transplantation. Note elevated plasma gastrin levels during anuric period. immediately after transplantation. As renal function improwes plasima gastrin llewels rekurnt to normal. 


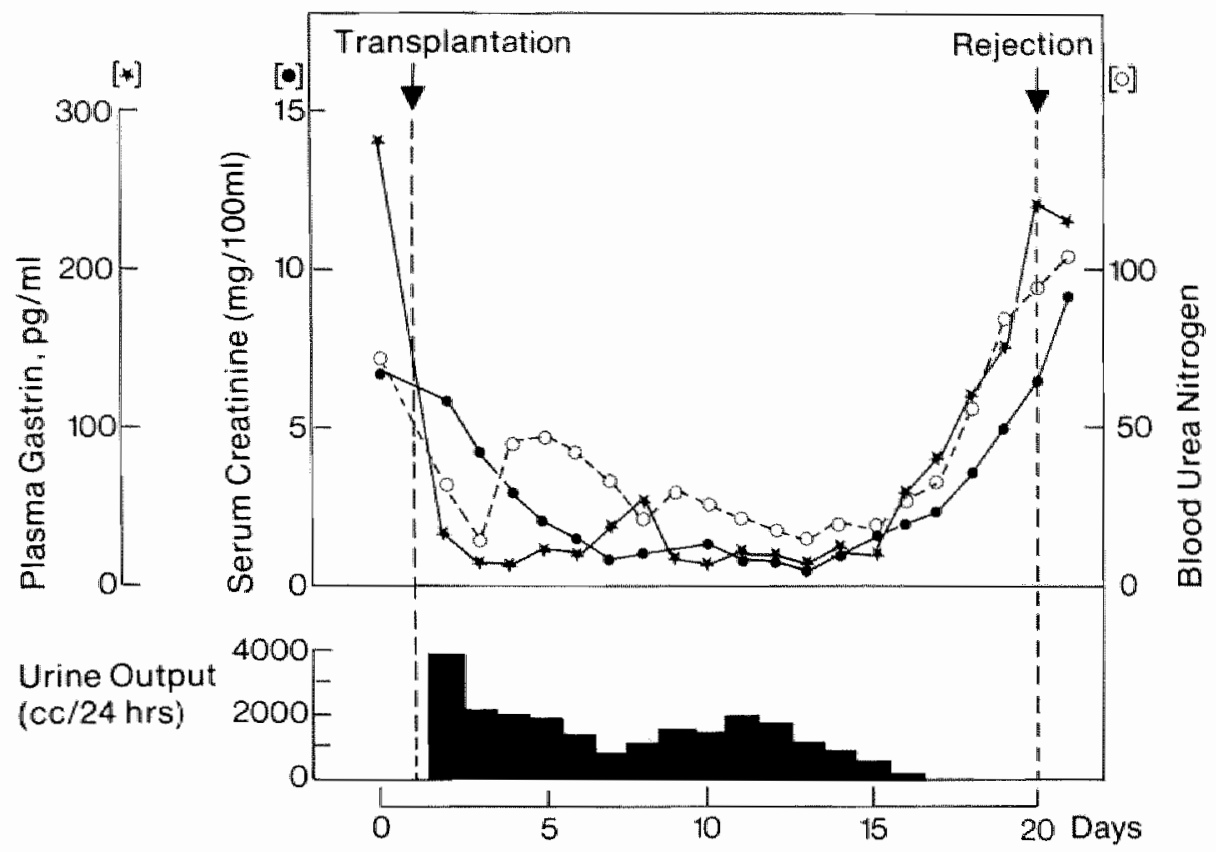

Figure 24. Plasma gastrin, serum creatinine, blood urea nitrogen, and urinary volume in an anephric patient (female, 24 yr) before and after kidney transplantation. Note rise of plasma gastrin during rejection episode.

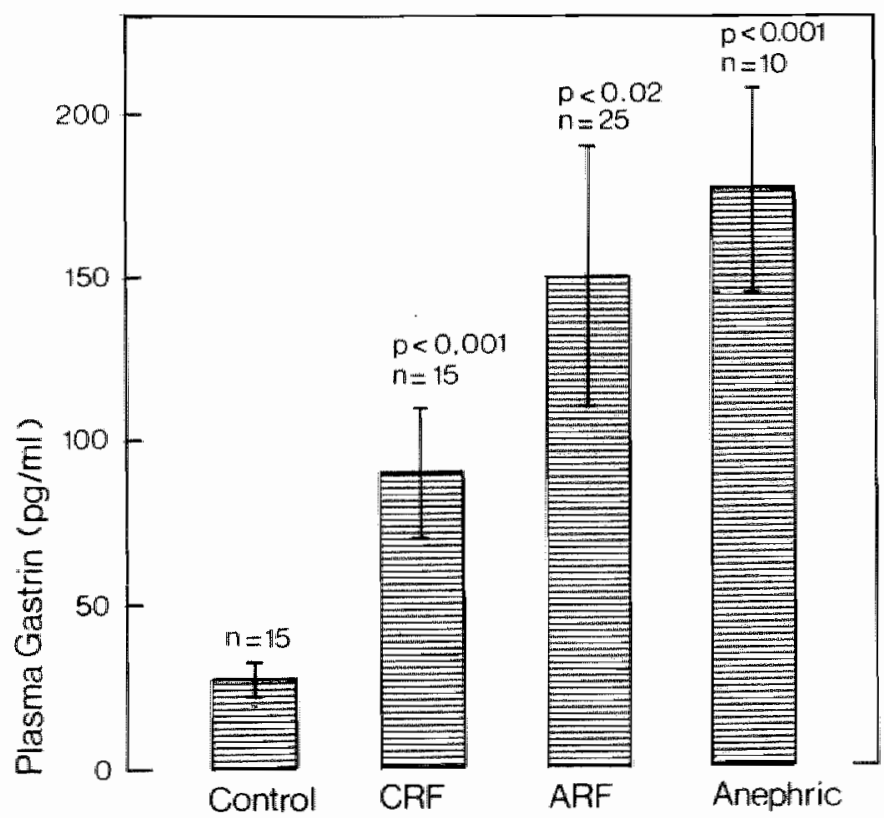

Figure 25. Mean plasma gastrin levels ( I S. E. I in the three groups of patients studied anephric patients awaiting transplantation, patients with chronic (CRF) and acule renal fail Lre (ARF). 
patients (CRF) from $297 \pm 186 \mathrm{pg} / \mathrm{ml}$ pre- to $252 \pm 182 \mathrm{pg} / \mathrm{ml}$ post-dialysis (corr t-test, $t=4.3, p<0.001$ ) (figure 26).

Gastric acid secretion studies showed a consistent pattern in all the 3 groups of patients, of a low $\mathrm{BAO}$, a high basal intragastric $\mathrm{pH}$ and a very significant release of gastric acid secretion upon pentagastrin stimulation, especially in the anephric group (figure 27). The mean $\mathrm{BAO}$ was $0.1 \pm 0.06 \mathrm{mEq} / \mathrm{hr}, 0.2 \pm 0.04$ $\mathrm{mEq} / \mathrm{hr}$ and $0.2 \pm 0.06 \mathrm{mEq} / \mathrm{hr}$ in the anephric, CRF and ARF patients

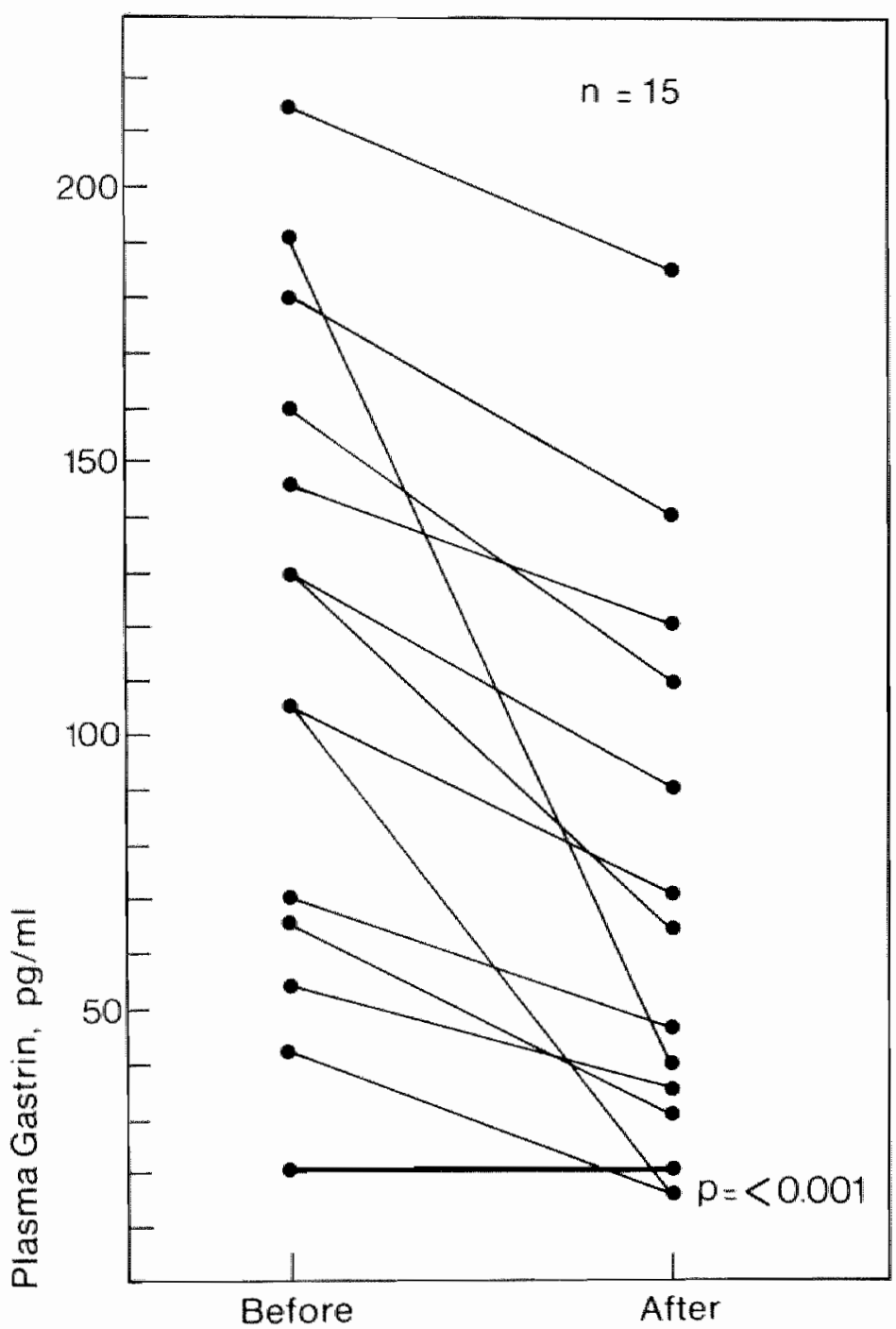

Figure 26. Plasma gastrin levels before and after hemodialysis in 15 patients (CRF) which show a significant decrease of plasma gastrin (correlated (-test $t=4,3, P<0.001$ ). 
respectively with a corresponding low mean basal intragastric pH of $6.4 \pm 0.8$ (anephric), $6.8 \pm 0.4$ (CRF) and $6.2 \pm 0.2$ (ARF). The mean PAO in the amephric patients was $32.1 \pm 4.4 \mathrm{mEq} / \mathrm{hr}$ while in the two other groups the mean PAO was within normal range of 22.0 I $3.2 \mathrm{mEq} / \mathrm{hr}$ (CRF) and $20.1 \pm 2.8 \mathrm{mEq} / \mathrm{hr}$ (ARF). As a primary relationship between elevated $\mathrm{PG}$ and serum calcium levels is suggested by most reported clinical studies $(25,79,80,81)$ we measured plasma calcium levels in 15 CRF patients as well as in 8 anephric patients. The mean plasma calcium level in these 2 groups was within normal range of $8.1 \mathrm{mg} / 100 \mathrm{ml}$ before to $7.8 \mathrm{mg} / 100 \mathrm{ml}$ after dialysis (CRF) and $9 \mathrm{mg} / 100 \mathrm{ml}$ before to $8.4 \mathrm{mg} / 100 \mathrm{ml}$ after transplantation. Finally, we were unable to find any correlation between PG levels and BAO or PAO or between PG levels and BUN or creatinine in these three groups of patients with different degrees of renal failure.

\section{Discussion}

Although it is known that radiolabeled gastrin accumulates in the renal cortex and that the cortex can inactivate gastrin in vivo (68) and in vitro (82), the exact mechanism of degradation is unknown. Davidson and coworkers (83) have suggested that the removal of gastrin from the circulation during passage through the kidney is a result of direct uptake from the peritubular capillary blood, as has also been described for insulin, pro-insulin and the $\mathrm{C}$-peptide of pro-insulin (84).

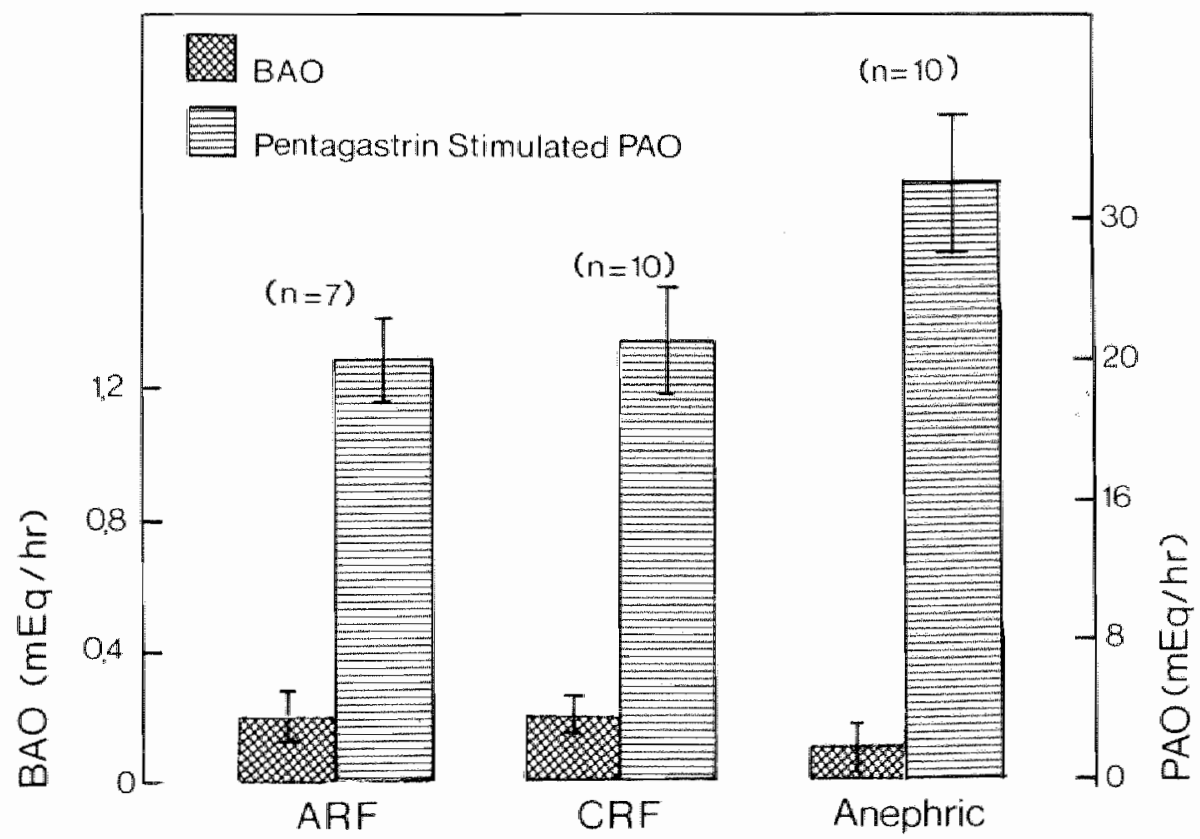


Recently, an enzymatic activity has been described in perfused rat kidney that catalyzes cleavage of the C-terminal dipeptide amide from gastrin terrapeptide (72) but it is not known if this is also active against whole gastrin and the different molecular forms of gastrin. But as gastrin is not excreted in the urine in any significant or detectable amount, it is presumably metabolized in the kidney. Impaired renal function would then result in an impaired metabolism of gastrin. Our clinicall results seem to support this concept since all anephric patients and $55 \%$ and $50 \%$ of patients with respectively CRF and ARF had consistent elevated PG levels, whille PG levels decreased dramatically after kidney transplantation or when the kidney function returned to normal in the ARF patients.

Very interesting was the finding in 2 patients of an increase in $P G$ levels during rejection of the transplanted kidney. This increase in PG tended to be earlier and maybe even more sensitive than the rise in BUN and creatinine when the transplanted kidney is being rejected.

The fact that $50 \%$ of AFF patients and $55 \%$ of CAF patients thad elevated PG levels may indicate that of the various pathologic changes in the kidney, only some involve the gastrin inactivating mechanism and that when in ARF patients elevated PG levels decrease, as renal function improves, there is a recovery of the same mechanism. However, in the different pathologic changes, we were unable to show a correlation between PG levels and BUN or serum creatinine. We have no good explanation for the five ARF patients with $P G$ values in the $Z E$-range during their period of acute renal failure, which were higher than in the anephric patients. A possible explanation might be that in CRF and in anephric patients, in a chronic situation, other gastrin metabolism-systems, such as small bowel and fundus of the stomach (85) have partially assumed the kidney"s function, and alternatively that an trophic gastritis may be present as well.

That the elevated PG levels are not an effect of the uremia per se, has been demonstrated in experiments in which nephrectomized rats showed a very significant increase in PG values while bilateral ureteral ligation showed the same increase in BUN, but failed to increase PG lievels (83).

Our results of a moderate but significant decrease of $P G$ levels during hemodialysis are at variance with other reports $(76,86,87)$ where no decrease was found. The pore of the dialysis membrane used in our dialysis unit, permits molecules with a molecular weight of less than 18.000 to pass, which would mean that theoretically $G-17, G-13$ and $G-34$ can pass through the membrane. Gastro-intestinal bleeding and peptic ulceration of the stomach and duodenum has been suggested to be more common in anephric patients and in patients with renal failure, although the incidence in the different series varies between $10 \%$ and $50 \%(77,88-91)$ with a higher incidence in the smaller series. The role of gastric acid secretion in the development of these gastroduodenal lesions in uremia has been evaluated by a number of investigators, but the results of the different clinical studies are conflicting and vary from a low BAO and $\mathrm{PAO}(92)$ to normal values $(88,93)$, to gastric acid hypersecretion (91). We found a very low BAO with a high basal intragastric pH in all the three groups of patients. This probably reflects the neutralizing effect of a high gastric ammonia content, corresponding to the blood urea nitrogen level. Several studies have shown that the concentration of gastric juice ammonia is a function of the blood urea nitrogen concentration and that the gastric ammonia is derived from the plasma urea through gastric urease activity $(94,95)$.

We were unable to show any correlation between basal PG levels and BAO or 
basal intragastric $\mathrm{pH}$, which may indicate that the increased basal PG levells are not the result of decreased acid inhibition, but further studies are necessary to confirm this.

Pentagastrin-stimulated gastric acid secretion (PAO) was normal in the ARF and CRF patients. This suggests that while there is a neutralizing effect of gastric ammonia in the basal state, there is no such effect after pentagastrin stimulation in ARF and CRF patients, and a high parietal cell response in the anephric patients, perhaps secondary to chronically elevated $P G$ levels which may partially explain the gastropathy present and the increased incidence of gastrointestinal bleeding in patients with different degrees of renal insufficiency

\section{References}

\section{Hansky J.}

Clinical aspects of Gastrin physiology.

Med.Clin. of N.America 58:1217,1974.

2 Walsh J.H. and Grossman M.I.

Gastrin (second of two parts).

N.Eng.J.Med. 1377, 1975 .

3 McGuigan J.E. and Trudeau W.L.

Serum gastrin levels before and after vagotomy and pyloroplasty or vagotomy and antrectomy.

N.Eng.J.Med, 286:184, 1972.

4 Kronborg O., Stadil F., Rehfeld J.

Relationship between serum gastrin concentrations and gastric acid secretion in duodenal ulcer patients before and after selective and highly selective vagotomy.

Scand.J.Gastroent. 8:491,1973.

5 Jaffe B.M., Clendinnen B.G., Clark R.J.

Effect of selective and proximal gastric vagotomy on serum gastrin.

Gastroenterology 66:944,1974.

6 Fischer J.E., Kragelund E., Nielson A., and Wesdorp R.I.C.

Basal and meat extract plasma gastrin before and after parietal cell vagotomy and selective gastric vagotomy with drainage in patients with duodenal ulcer. Ann.Surgery 183:167,1976.

7 Cohen S., Lipshutz W. and Hughes $W$.

Role of gastrin supersensitivity in the pathogenesis of lower esophageal sphincter function in achalasia.

J.Cilin. Invest. 50:1241, 1971.

\section{Zollinger R.M. and Ellison E.H.}

Primary peptic ulcerations of the jejunum associated with islet cell tumors of the pancreas.

Ann.Surg. 142:709,1955.

9 Gregory R.A., Grossman M.I., Tracy H.J. and Bentley P.H.

Nature of the gastric secretaguogue in Zollinger-Ellison tumors.

Lancet II:543,1967.

10 Gregory R.A., Tracy H.ل..., French J.M. and Sircus W.

Extraction of a gastrin like substance from a pancreatic tumor in a case of Zollinger-Ellison syndrome.

Lancet I: 1045, 1960.

\section{Lamers C.B.H.W.}

Some aspects of the Zollinger-Ellison syndrome and serum gastrin.

Thesis. University of Nijmegen, 1976. 
12 Bonfils S, and Baden J.P.

The diagnosis of Zollinger-Ellison syndrome with special reference to multiple endocrine adenomas.

In Progress in Gastroenterology vol.2, Ed. Glass, published by Grune \& Stratton Inc New York pp. 332.1970.

13 Ellison E.H. and Wilson S.D.

Zollinger-Ellison Syndrome: Reappraisal and evaluation of 260 registered cases.

Ann.Surg. 160:512,1964

14 Isenberg J.I., Walsh J.H. and Grossman M.I.

Zollinger-Ellison Syndrome.

Gastroenterology 65:140,1973

15 Willson S.D.

Ullcerogenic tumors of the pancreas: the Zollinger-Ellison Syndrome.

In "The Pancreas" Ed.Carey. Published by C.V.Mosby Co St.Louis pp.295,1973.

16 Ellison E.H. and Wilson S.D.

Ulcerogenic tumor of the pancreas

Progr.Clin. Cancer 3:225.1967.

17 McGuigan J.E.

Consequence of excess hormonal secretion in digestive disease.

Mayo Clin Proc. 48:634,1973.

18 Dreiling O.A. and Greemstein A.

Pancreatic function in patients with the Zollinger-Ellison Syndrome.

Am.J.Gastroent. 58:66,1972.

19 Gregory R.A.

The gastrointestinal hormones: A review of recent advances.

J.Physiol. 241:1,1974.

20 Thompson J.C., Reeder D.D., Villar H.V. and Fender H.R.

Natural history and experience with diagnosis and treatment of the Zollinger-

Ellison Syindrome.

Surg.Gyn \& Obstet. 140:721,1975

21 Winship D.H. and Ellison E.H.

Variability of gastric secretion in patients with and without Zollinger-Ellison

Syndrome.

Lancet I: $1128,1967$.

22 Thompson J.C." Reeder D.D. and Buchanan H.A.

Glinical role of serum gastrin measurements in the Zollinger-Ellison Syndrome Am.J.Surg. 124:250,1972.

23 Cameron A.J. and Holfman H.M.

Zollinger-Ellison Syndrome.

Mayo Clin. Proc. 49:44,1974.

24 Ballard H.S., Frane B., and Hartsock R.J.

Familial multiple endocrine adenoma-peptic ulcer complex.

Medicine 43:481,1964.

25 Dent R.I., James J.H., Wang C.A., Deftos L.J., Talamo R. and Fischer J.E. Hyperparathyroidism, gastric acid secretion and gastrin.

Ann Sura. 176:360, 1972 .

26 Moldawer M.P., Nardi G.L. and Balur J.W.

Concomitance of multiple adenomas of the parathyroids and pancreatic islets with tumor of the pituitary. A syndrome with famil al incidence.

Am.J.Med. 228:190,1954.

27 Bradley E.L., Galambos J.T., Lobley C.R. and Chan Y.K. Secretin-gastrin relationship in Zollinger-Ellison Syndrome

Surg. $73: 550,1973$.

28 Wilder W.T., Frame B., Haubrich W.S. 
Peptic ulcer in hyperparathyroidism.

Ann. Intern. Med. 55:885, 1961.

29 Barreras $R$.

Calcium and gastric secretion.

Gastroenterology 64:1168,1973.

30 Christiansen J., Aagaard P.

Parathyroid ademoma and gastric acid secretion.

Scand.J.Gastroent. 7:445,1972.

31 Stremple J.F., Watson C. G.

Serum calcium and gastrin and gastric acid secretion before and after parathyroidectomy for hyperparathyroidism.

Surgery $75: 841,1974$

\section{Friesen S.}

Zollinger-Ellison Syndrome. Current Problems in Surgery (Ravitch M. ed.)

Chicago, Year Book Medicall Publishers, April 1972.

\section{Robinson $W$.}

Need for further study about the role of the parathyroids in Cushings Syndrome (Abstr).

J.Clin. Endocrim Metabol. 14:811,1954.

34. Cope 0.

Hyperparathyroidism: diagnosis and management.

Am.d.Surg. 99:394, 1974.

35 Barreras R.F., Donaldson R.M.

Role of calcium in gastrin hypersecretion, parathyroid adenoma and peptic ulcer.

N.Engl.J.Med. 272:1122,1967.

36 Hughes W.S., Hawker C.O., Brooks F.P., Utiger R.O.

The relationship between serum gastrin, parathyroid hormone and calcium.

Clin Res. 18:607,1971.

37 Holtermuller K.H., Goldsmith R.S., Zizemore G.W., Go V.L.W.

Dissociation of gastric acid and serum gastrin responses to intraluminal

calcium in man: influence on calcitonin and parathyroid hormone.

Gastroenterology 67:1101,1974.

38 Reeder D.D., Jackson B.M., Ban J. et al.

Influence of hypercalcemia on gastric acid secretion and serum gastrin concentration in man.

Ann. Surg. 172:540,1970.

39 Trudeau W.L., McGuigan J.E.

Effects of calcium on serum gastrin levels in the Zollinger-Ellison Syndrome.

N. Engl. Med 281:862, 1969 .

40 Levant J.A., Walsh J.H., Isenberg J.I.

Stimulation of gastric secretion and gastrin release by single oral doses of calcium carbonate in man.

N. Engl.J.Med. 289:555, 1974.

41 Friesen S.R., Hermreck A.S., Mantz F.A.

Glucagon, gastrin and carcinoid tumors of the duodenum, pancreas and stomach: polypeptide "Apudomas" of the foregut.

Am.J.Surg. 127:90,1974.

42 Law D.H., Liddle G.W., Scott H.W.Jr., et al.

Ectopic production of multiple hormones (ACTH, MSH and gastrin) by a single malignant tumor.

N.Eng.J.Med. 273:292,1965.

43 Murray-Lyon I.M., Eddllestone A.L.W.F., Williams R. et al.

Treatment of multiple hormone producing malignant islet-cell tumor with streptozotocin. 
Lancet 2: 895, 1968.

44 Korman M.G., Soveny $\mathrm{C}_{\text {, }}$, Hansky J.

Gastrin studies in gastric ulcer.

Gut 13:166,1972.

45 Ganguli P.C., Hunter W.M.

Radioimmunoassay of gastrin in human plasma.

J.Physial.London 220:499,1972.

46 Korman M.G., Soveny C., Hansky J.

Serum gastrin in duodenal ulcer.

Gut 12:899.1971.

47 Trudeau W.L., McGuigan J.E.

Differences in rates of gastrin release in normal individuals, patients with

duodenal ulcer and following gastric surgery.

Gastroenterology 62:822,1972.

48 Stadil F, Rehfeld J.E.

Radioimmunoassay of gastrin in human serum.

Scand.J.Gastroent, suppl. 9:61,1971.

49 Stern D.H., Walsh J.H.

Rellease of gastrin in postoperative duodenal ulcer patients.

Gastroenterology 62:817,1972.

50 Feurle G., Ketterer H., Becker H.D., Creutzfeldt W.

Circadian serum gastrin concentrations in control persons and in patients with ulcer disease.

Gastroenterology $7: 177,1972$.

51 Reeder D.D., Jackson B.M., Ban J.L., Davidson W.D., Thompson J.C.

Surg. Forum 21:290,1970.

52 Byrnes D.J., Young J.D., Chisholm D.J., Lazarus L.

Serum gastrin in patients with peptic ulceration.

Br.Med. . i ii,626, 1970.

53 Hansky J., Korman M.G.

Immunoassay studies in peptic ullcer

Clin.Gastroent. 2:275,1973.

54 Trudeau W.L., McGuigan J.E.

Relations between serum gastrin levels and rates of gastric hydrochloric acid secretion.

New Engl.J.Med. 284:408,1971

55 Gedde-Dahi D.

Radioimmunoassay of gastrin. Fasting serum levels in humans with normal and high gastric acid secretion.

Scand.J.Gastroent. 9:41,1974.

56 Herring D.W., Blair E.L.

Gastrin activity in the plasma of normal subjects in patients with duodenal ulceration.

Br.J.Surg. 56:707,1969.

57 Gangull P.C., Polak J.M., Pearse A.G.E., Edler J.B., Hegarty M.

Antral-gastrin-cell hyperplasia in peptic ulcer disease.

Lancet I: $583,1974$.

58 Yalow R.S., Berson S.A.

Further studies on the nature of immunoreactive gastrin in human plasma.

Gastroenterology 60:203, 1971.

59 Nilsson G. Yalow B.S., Berson S.A.

Distribution of gastrin in gastrointestinal tract of human, dog. cat and hog in

"Frontiers in Gastrointestinal Hormone Research" Nobel Symposium XVI,

Ed. S.Anderssan, published by Almquist and Wiksell, Stockholm, pp. 95,1973.

60 Stern D.H., Walsh J.H. 
Gastrin release in postoperative ulcer patients.

Evidence for release of duodenal gastrin.

Gastroenterology $64: 363,1973$.

61 Wesdorp R.I.C., Funovics J.M., Hirsch H., Fischer J.E.

Characteristics of release of duodenal gastrin.

Surgical Forum XXVI, 383,1975.

62 McGuigan J.E., Herbst C.A.

Separate immunochemical measurements of heptadecapeptide and big gastrin by use of region specific antibodies to gastrin.

Gastroenterology 66:854,1974.

63 Dockray G.J.., Walsh J.H.

$\|$ dentification of an $N$-terminal fragment of heptadecapeptide gastrin in the serum of patients with Zollinger-Ellison Syndrome.

Gastroenterology 66:874,1974.

64 Glass J.O., Schwartz I.L. and Rodevich W.

Enzymatic inactivation of peptide hormones possessing a C-terminal amide group.

Proc.Nat.Acad.Sci. 63:1426,1969.

65 Martin T.J., Melich R.A. and de Louise M.

Metabolism of parathyroid hormone. Degradation of ${ }^{25}$ /-labeled hormone by a kidney enzyme.

Biochem.J. 3:509, 1969.

66 Rabkin R., Simon H.M., Steiner S. and Colwell J.A.

Effect of renal disease on renal uptake and excretion of insulin in man.

N.Engl.J.Med. 282:182,1970.

67 Walsh J.H. and Grossman M.I.

Gastrin (first of two parts).

N.Engl.J.Med. 1323,1975

68 Clendinnen B.G., Davildson W.O., Reeder D.D., Jackson B.M. and

Thompson J.C.

Renall uptake and excretion of gastrin in the dog.

Surg.Gyn.\&Obstet. 132:1039,1971.

69 Booth R.A.D., Reeder D.D., Hjelmquist U.B., Brandt E.N., and

Thompson J.C.

Renal inactivation of endogenous gastrin in dogs.

Arch. Surg. 106:851,1973.

70 Davidson W.D., Springberg P.O., Falkinburg N.R.

Renal extraction and excretion of endogenous gastrin in the dog.

Gastroenterology 64:955, 1973.

71 Thompson J.C., Becker H.D., Evans J.C.W., Hjelmquist U.B.E., Brandt E.N. and Reeder D.D.

Studies on the catabolism of gastrin.

In Endocrinology of the Gut, Ed. Chey \& Brooks, published by Charles B. Slack Inc. pp. 295,1974.

72 Walter R, and Bowman R.H.

Mechanism of inactivation of vasopressin and oxytocin by the isolated perfused rat kidney.

Endocrinology $92: 189,1973$.

73. Walsh J.H. and Laster L.

Enzymatic deamidation of the C-terminal tetrapeptide amide of gastrin by

mammalian tissue.

Biochem. Med. 8:432,1973.

74 Maxwell J.G., Moore J.G., Dixon J. and Stevens L.E.

Gastrin levels in anephric patients. 
Surg. Forum:305, 1971.

75 Dent R.I., Hirsch H., James J.H., Fischer J.E.

Hypergastrinema in patients with acute renal failure.

Surg. Forum :312,1972.

76 Korman M.G., Laver M.C. and Hansky J.

Hypergastrinemia in chronic renal fallure.

Br.Med.J. 1:209,1972.

77 Shepard A.M.M., Stewart W.K. and Wormsley K.G.

Peptic uliceration in chronic renal failure.

Lancet: 1357,1973.

78 Shepard A.M.M., Stewart W.K., Thjodleifsson B. and Wormsley K.G.

Further studies on gastric hypersecretion in chronic renal failure.

Br.Med J. 96,1974.

79 Barreras $\mathbf{R}$.

Calcium and gastric secretion.

Gastroenterology 64:1168,1973.

80 Stremple J.F. and Watson C.G.

Serum calcium and gastrin and gastric acid secretion before and after parathyroidectomy for hyperparathyroidism.

Surgery $75: 841,1974$.

81 Hughes W.S., Hawker C.O., Brooks F.P. and Utiger R.O.

The relationship between serum gastrini, parathyroid hormone and calcium.

Clin.Res. 18:607,1971.

82 Dent R.I., Levine B., James J.H., Hirsch H. and Fischer J.E.

Effects of isolated perfused canine lung and kidney on gastrin

heptadecapeptide.

Am.J.Physiol. 225:1038,1973.

83 Davidson W.O., Moore T.C., Shipey W. and Conovaloff A.J.

Effect of bilateral nephrectomy and billateral utereral ligation on serum gastrin levels in the rat.

Gastroenterology 66:522,1974

84 Katz A.I., and Rubenstein H.H.

Metabolism of pro-insulin, insulin and $\mathrm{C}$-peptide in the rat.

J.Clin. Invest. 52:1113,1973.

85 Temperley J. M., Stagg B.H. and Wyllie J.H.

Disappearance of gastrin and pentagastrin in the portal circulation.

Gut $12: 372,1971$.

86 Durkin M.G., Essig L.J. and Nolph K.D.

Peritoneal dialysis of gastrin (abstr.).

Clin. Res. 20:40, 1972

87 Reeder D.D. and Thompson J.C.

Effect of hemodialysis on serum gastrin levels in uremic patients (abstr.).

Gastroenterology 60:795,1971

88 Goldstein H., Murphy D., Sokal A. and Rubini M.E.

Gastric acid secretion in patients undergoing chronic dialysis.

Arch. Intern. Med. 120;645,1967.

89 Hadjiyannakis E.J., Evans D.B., Smellie W.A.B. and Calne R.Y.

Gastrointestinal complications after renal transplantation.

Lancet II : 781, 1971.

90 Moore T.C. and Hume D.M.

The period of nature of hazard in clinical renal transplantation. I. The hazard to patient survival.

Ann.Surg. 170:1,1969.

91 Verkanteswaren P.S., Jeffers A. and Hocker A.G.

Gastric acid secretion in chronic remal faillure. 
Br.Med.J. 4:22,1972.

92 Lieber C.S. and Lefevre A.

Ammonia as a source of gastric hypoacidity in patients with uremia.

J.Clin. Invest. 38:1271,1959.

93 Gingell J.C. Burns G.P. and Chishold G.D.

Gastric acid secretion in chronic uremia and after renal transplantation.

Br.Med.J. 4:424,1968.

94 Von Korff R.W., Ferguson D.J. and Glick D.

Role of urease in the gastric mucosa in gastric juice of histamine-stimulated dog.

Am.J.Physial. 165:695,1951.

85 Meyers S. and Lieber C.S.

Reduction of gastric ammonia by ampicillin in normal and azotemic subjects. Gastroenterology $70: 244,1976$. 


$$
76
$$




\section{Chapter IV}

\section{General discussion and summary}

In this thesis, additional clinical and experimental data are provided as a contribution to unravel the physiological and clinical significance of gastrin.

With a very specific and sensitive radioimmunoassay whose characteristics are described in Chapter 1, experimental and clinical studies were performed at the Laboratory of Surgical Physiology and the departments of Surgery and Medicine of the Massachusetts General Hospital in Boston (U.S.A.). In Chapter 11 , following a brief review of the actions, sites of production and the release in vivo, the release of gastrin in vitro from isolated rat antra is studied by perfusing the rat antra in an adapted perfusion set up with different releasing agents in an oxygenated Krebs-Ringers-A solution.

Upon perfusion with $50 \mathrm{mM}$ acetylcholine $(+0.1 \mathrm{mM}$ eserine) the mean gastrin levels in the effluent increased within 2 minutes to 4 times the basal level, while there was a smaller but significant secondary release after 20 minutes. During perfusion with $50 \mathrm{mM}$ glycine and $10 \mathrm{mM}$ or $30 \mathrm{mM}$ calciumchloride containing Krebs-Ringers-A solution, gastrin levels in the effluent increased within 4 minutes to twice the basal level, without a secondary release of gastrin. Control perfusions with eserine alone or with Krebs-Ringers-A solution failed to release gastrin in vitro. The apparent biphasic release of gastrin in vitro with acetylcholine is a new finding and may suggest that the initial peak consists only of stored gastrin and the second peak of newly synthetized gastrim. stimulated only by the physiological stimulus acetylcholine, but not by other releasers. It is not unreasonable to assume that perhaps by acetylcholine synthesis of gastrin is stimulated as well. This is in accordance with the finding of a glucose induced biphasic release of insulin in vitro which is enhanced by acetyllcholine. However further perfusion studies, with for example Actinomycine-D treated rats to block synthesis, are necessary.

As gastrin containing G-cells have been demonstrated in the duodenum of man and dog and very little is known about the characteristics of release of duodenal gastrin, we studied the release of duodenal gastrin in an acute experiment in 13 healthy mongrel dogs. Under general anesthesia, a mucosal antrectomy was performed to exclude the contribution of antral gastrin, following which basal gastrin levels fell significantly.

Three general types of stimulation were administered: "vagal" stimulation with either insulin or 2 deoxy-D-glucose, local perfusion with various solutions known to release antral gastrin and distension of the duodenum.

Acetylcholine at $\mathrm{pH} 7$, but not at $\mathrm{pH} 1.5$, and insulin hypoglycemia but not 2-deoxy-D-glucose did release duodenal gastrin. Glycine ( $\rho H 7)$, physiological saline $(\mathrm{pH} 7)$ and balloon distension failed to release duodenal gastrin. These findings show some distinct differences in release characteristics between canine antral and duodenal gastrin.

However, these experiments cannot be taken as excluding the role of distension or food in releasing duodenal gastrin in man, but they confirm the suggestion that canine duodenal gastrin is of less consequence than in man, where in climical studies a significant post-prandial rise in plasma gastrim is seen after total gastrectomy, in contrast to the dog. In respect to the clinical significance, the contribution of duodenal gastrin may especially be important after a highly 
selective vagotomy after which the antrum and duodenum are intact and vagally inmervated.

In Chapter III, three prospective clinical studies are reported after a brief review of the Zollinger-Ellison syndrome as an introduction to the first clinical study concerning plasma and parathyroid tumor tissue gastrin in hyperparathyroidism.

Hyperparathyroidism thas been associated with an increased incidence of duodenal ulcer, increased acid secrelion, and increased plasma gastrin levels. A relationship between these changes, increased serum calcium levels, and the increased incidence of peptic ulceration has been suggested, especially since increased plasma gastrin levels, serum calcium levels, and gastric acid secretion decrease after parathyroidectomy. We have previously suggested that the decrease in plasma gastrin levels after parathyroidectomy may suggest an extragastric source of gastrin, whereas others using immunofluorescent studies have suggested that the parathyroid adenomas themselves might be the source of the gastrin, as there is growing evidence that also the parathyroid cells are of neuroectodermal origin and belong to the APUD-cells.

Prospectively fifteen patients were studied with primary hyperparathyroidism. Plasma gastrin and serum calcium levels before and after parathyroidectomy. as well as the gastrin content of parathyroid tumor tissue, were measured. The mean basal plasma gastrin level before operation was significantly greater than that of a control group and decreased insignificantly after operation, in contrast to serum calcium levels. No positive correliation could be found between plasma gastrin and serum calcium levels before and after operation. Parathyroid tumor tissue was assayed for gastrin content by radioimmunoassay and no detectable amounts of gastrin could be recovered from any tumor. These results do not support the concept that the extragastric source of gastrin in patients with hyperparathyroidism is the parathyroid adenoma itself, as is suggested by the APUD-cell concept.

As the precise role of gastric acid secretion and gastrin in the pathogenesis of peptic ulceration is still unknown and only in the Zollinger-Ellison syndrome there is a direct relationship between very high basal gastrin levels, increased rates of gastric acid secretion and ulcer disease, we studied the relation between basal plasma gastrin (PG) levels, basal intragastric $\mathrm{pH}$ and basal (BAO) and stimulated (PAO) gastric acid secretion in 132 patients with peptic ulceration of which 101 had a duodenal ulcer (D.U.) and 31 a gastric ulcer (G.U.).

While the mean basal PG for the 101 patients with D.U. was $61 \pm 7 \mathrm{pg} / \mathrm{ml}$, only slightly higher than that of a control group $(54 \pm 9 \mathrm{pg} / \mathrm{mll})$, the mean basal PG in the G.U. patients $(93+17 \mathrm{pg} / \mathrm{m} /)$ was higher than that in the control group $(p<0.05)$. The mean basal intragastric pH was, as expected, significantly lower $(p<0.02)$ in the D.U. patients $(1.8 \pm 0.06)$ than in the G.U. patients $(2.6 \pm 0.01)$. In the entire series basal $\mathrm{PG}$ seemed to be related to basal intragastric $\mathrm{pH}$, but, when the 132 patients were grouped according to their intragastric $\mathrm{pH}$ and their basal PG was compared ${ }_{i}$ the relationship disappeared. Also, when the cases were grouped according to their B.A.O. or P.A.O., and their basal PG was compared, there was no decrease in $P G$ levels as acid secretion increased progressively. Conclusively, we were not able to find any relation between PG levels and gastric acid secretion in D.U. or G.U. patients. The finding of normal levels of PG in D.U. patients implies some autonomy of gastrin release in this disease. There is some support for this concept in the 
few reports of PG levels measured by bio-assay in plasma for D. U patients which were significantly higher than in normal subjects. Alternatively, basal acid secretion neither determines nor is dettermined by plasma gastrin.

The kidneys are well established as a major site of accumulation and degradation of many hormones, including gastrin. Clinical studies have demonstrated increased plasma gastrin levels in anephric patients and in patients with severe renal disease, and alithough it is known that there is a high incidence of gastritis and upper gastro-intestinal bleeding and ulceration in patients withrenal failure. comparatively little attention has been paid to gastric acid secretion in these patients, as it has been assumed that the formation of gastric ammonia decreased titratable acidity. In a prospective study in three groups of patients, we measured daily basal plasma gastrin levels in 10 anephric patients awaiting transplantation, in 8 transplanted patients, in 15 patients with chronic renal failure (CRF) before and after hemodialysis and in 30 patients with acute renal failure (ARF). Significant elevated $P G$ levels were found in all the anephric patients, in $50 \%$ of ARF patients and in $55 \%$ of CRF patients what would seem to indicate that only certain pathologic changes involve the gastrin inactivating mechanism. Elevated PG levels decreased to normal after kidney transplantation or when the kidney function returned to normal in ARF patients, suggesting a recovery of the same mechanism.

Gastric acid secretion studies performed in the three groups of patients showed a consistent pattern in all the patients of a low $B A O$, a high basal intragastric $\mathrm{pH}$ and a very significant PAO. This suggests that while there is a neutralizing effect of gastric ammonia in the basal state, there is no such effect after pentagastrin stimulation in ARF and CRF patients, and a high parietal cell response in the anephric patients, perhaps secondary to chronically elevated $P G$ levels, which may partially explain the increased incidence of gastrointestinal bleeding and gastropathy seen in patients with different degrees of renal failure.

In this thesis a few new findings and suggestions concerning the physiological and clinical significance of gastrin have been made, but the tale is far from being told.....

A great problem in evaluating and comparing gastrin levels in clinical and experimental studies is that we measure only total gastrin immunoreactivity. which differs from laboratory to laboratory, as most antisera, although raised against synthetic human or crude porcine gastrin, differ from laboratory to laboratory. Although with most antisera, it seems that $\mathrm{G}-13, \mathrm{G}-17$ and $\mathrm{G}-34$ are immunochemically identical, the exact immunoreactive components of gastrin measured by one's assay are not precisely known. Studies with specific antisera raised against the different synthetic molecular forms of gastrin are needed to define more clearly the physiological and clinical significance of its molecular heterogeneity. Clarification is also needed of the relationship between the different gastrin molecules and whether they are produced independently or by enzyme degradation from the largest molecule. 


\section{Samenvatting}

In dit proefschrift dat gebaseerd is op 7 artikels wordt een bijdrage geleverd aan het onderzoek naar de fysiologische en klinische betekenis van het gastro-intestinale hormoon gastrine.

Met behulp van een zeer specifieke en gevoelige radio-immunoassay, welke in het eerste hoofdstuk beschreven wordt, werden experimentele en klinische onderzoekingen verricht op het laboratorium voor chirurgische fysiologie en op de afdeling Algemene Heelkunde en Interne van het Massachusetts General Hospital in Bosten (U.S.A.).

In het tweede hoofdstuk wordt na een kort overzicht omtrent wat er tot op heden bekend is over de verschillende werkingen van gastrine, over de localisatie van de gastrine producerende cellen en over de uitscheiding in vivo, een onderzoek beschreven waarin de uitscheiding van gastrine in vitro is bestudeerd in geissoleerde rat antra. Deze rat antra werden in een proefopstelling geperfundeerd, met verschillende stoffen opgelost in een KrebsRingers-A oplossing. Tijdens perfusie met een $50 \mathrm{mM}$ acetylcholine $(+0.1 \mathrm{mM}$ eserine) oplossing stegen de gemiddelde gastrinewaarden binnen 2 minuten naar 4 maal de basale waarde, terwijl er na 20 minuten nogmaals een significante secundaire uitscheiding van gastrine plaatsvond. Tijdens perfusie met een $50 \mathrm{mM}$ glycine of een 10 en $30 \mathrm{mM}$ calciumchloride oplossing steeg de gemiddelde basale gastrinewaarde langzamer (4 minuten) naar 2 keer deze waarde, echter zonder de boven beschreven secundaire uitscheiding. Deze biphasische uitscheiding van gastrine in vitro na perfusie met acetylcholine is een geheel nieuwe bevinding en zou kunnen betekenen dat bij de eerste uitscheiding voornamelijk het $\mathrm{zg}$. opgeslagen gastrine wordt uitgescheiden, terwijl tijdens de tweede uitscheiding nieuw gesynthetiseerd gastrine wordt uitgescheiden, wat in dit geval alleen gesynthetiseerd zou worden ma stimulatie door de fysiologische stimulus acetylcholine, maar niet door andere stoffen die wel aanleiding geven tot een uitscheiding van gastrine. Een ondersteuning van deze theorie vinden we in de biphasische uitscheiding van insulline in vitro na stimulatie door glucose, welke nog versterkt wordt door acetylcholine. Echter verdere perfusiestudies, met bijvoorbeeld met actinomycine- $D$ behandelde ratten om de synthese van gastrine te blokkeren, zijn nog noodzakelijk.

Ook in het duodenum van de mens zowel als van de hond heeft men in de laatste jaren gastrine bevattende G-cellen kunnen aantonen.

Omdat er nog zeer weinig bekend is omtrent de eigenschappen en het uitscheidingsmechanisme van dit duodenale gastrine, bestudeerdlen wij de uitscheiding van het duodenale gastrine in een acuut experiment in 13 honden. Hierbij werd onder algehele narcose een zg. "'mucosal antrectomy" verricht om bijdrage van het antrale gastrine uit te sluiten. Na de verwijdering van de mucosa van het antrum daalde de gemiddelde basale gastrinewaarde significant. De uitscheiding van het duodenale gastrine werd op 3 manieren beproefd: stimulatie van de nervus vagus door middel van insuline en 2-deoxy-D-glucose, locale perfusie met verschilende oplossingen waarvan bekend is dat het een uitscheiding geeft van het antrale gastrine en een drukverhoging in het duodenum. Nu bleek dat acetylcholine van een $\mathrm{pH} 7$ en niet van een $\mathrm{pH} 1,5$ insuline hypoglycemie maar niet 2-deoxy-D-glucose aanleiding gaven tot uitscheiding van het duodenale gastrine. Glycine $(\mathrm{pH} 7)$, fysiologisch zout $(\mathrm{pH} 7)$ 
en uitzelting van het duodenum met behulp valn een opblaasbare ballon gaven geen uitscheiding te zien van het duodenalle gastrine. In deze experimenten zien wij dus duidelijke verschillen tussen het uitscheidingsmechanisme van het duodenale en antrale gastrine in de hond. Echter deze experimenten kunnen nog niet als maatgevend worden geduid woor de uitscheiding van het duodenale gastrine in de mens, en wel omdat recent gebleken is dat het duodenum van de mens aanzienlijk meer gastrine bevat dan het duodenum van de hond, en dat verder in enkele klinische studies een significant stijgen van het plasma gastrine wordt gezien na het innemen van voedsel bij patienten na een totale maagresectie, dit ook in tegenstelling tot de hond.

In hoofdstuk drie worden drie prospectieve klinische onderzaekingen besproken na een zeer beknopt overzicht van het Zollinger-Ellison syndroom als een inleiding tot de eerste klinische studie naar de oorsprong van de verhoogde plasma gastrinewaarden in patienten met een hyperparathyreoidie. Het is bekend dat in hyperparathyreoidie vaker het voorkomen van peptische ulcera wordt gezien, die gepaard kunnen gaan met een verhoogde maagzuursecretie en verhoogde plasma gastrinewaarden. Door vele auteurs wordt hier een verband aangegeven, zeker omdat na parathyreoidectomie deze verhoogde plasma gastrinewaarden en de zuursecretie zouden verminderen, evenals het serum calcium. In overeenstemming met de theorie rond de APUD-cell tumoren of APUDOMAS zouden deze verhoogde gastrinewaarden ook het gevolg kunnen zijn van productie van gastrime door de adenomen van het parathyreoud, wat in een enkele patient beschreven is. In 15 patienten met primaire hyperparathyreoidie werden plasma gastrine en serum calcium waarden gemeten , enkele malen vóór en enkele malen na een parathyreoidectomie. Tevens werd in het verwijderde parathyreoid tumorweefsel met behulp van de radioimmunoassay het gastrinegehalte gemeten. De gemiddelde basale plasma gastrinewaarde vóór operatie bleek inderdaad significant hoger te zijn dan die van de controlegroep, doch deze daalde niet significant na de operatie, dit in tegenstelling tot de serum calcium waarden. Wij konden verder ook geen positieve correlatie aantonen tussen de plasma gastrine en de serum calcium waarden vóo of na de operatie. In geen van deze 15 patienten bleek het verwijderde parathyreoidweefsel een spoor gastrine te bevatten. Deze resultaten ondersteunen dus niet de theorie dat, in patienten met hyperparathyreodie de verhoogde gastrinespiegels in het bloed een gevolg zijn van productie door de parathyreoid adenomen zelf, zoals dit voor vele APUDOMAS wel beschreven wordt.

Over de rol die het maagzuur en het gastrine spelen in de pathogenese van het peptisch ulcus is na jaren onderzoekingen nog zeer weinig bekend, en alleen in het Zollinger-Ellison syndroom zien wij een direct verband tussen de zeer hoge gastrinewaarden, de uitbundige maagzuursecretie en het optreden van multipele ulcera.

In een prospectief onderzoek gingen will de relatie na tussen basale plasma gastrinewaarden, de basale pH in de maag en de basale en gestimuleerde maagzuursecretie in 132 patienten met een ulcus pepticum, waarvan 101 een ulcus duodeni en 31 een ulcus ventricull hadden. Terwijl de gemiddelde basale plasma glastrinewaarde in de 101 patienten met een ulcus duodeni iets hoger was dan dat van de controlegroep, was de gemidlellde basale gastrinewaarde in de ulcus ventriculi patienten significant hoger dan wat van de controlegroep. Zoals verwacht was de gemiddelde basale $\mathrm{pH}$ van de maag in de ulcus duodeni patienten significant lager en de gemiddelde basale zuursecretie 
significant hoger dan die van de ulcus ventriculi patienten, wat er op lijkt te wijzen dat er een ongekeerde relatie bestaat tussen de basale plasma gastrinewaarden en de basale pH en zuursecretie in de maag. Echter, wanneer de 132 patienten gerangschikt werden naar hun $\mathrm{pH}$ in de maag en respectievelijk hun basale plasma gastrinewaarden vergeleken, dan verdween deze relatie geheel. Ook wanneer de patienten gerangschikt werden naar hun basale en gestimuleerde zuursecretie en hum basalle plasma gastrinewaarden vergeleken. was er geen verband aantoonbaar in de zin van een vermindering van de plasma gastrinewaarden wanneer de zuursecretie groter werd.

De bevinding van normale plasma gastrinewaarden in ulcus duodeni patienten, waarin men door de hogere zuursecretie eigenlijk veel lagere waarden zou verwachten, suggereert een zekere autonomie van de gastrine uitscheiding bij deze patienten. Deze bevinding wordt ondersteund door enkele publicaties waarin men met behulp van een bio-assay verhoogde plasma gastrinewaarden vond in ulcus duodeni patienten.

Verder is uit dit onderzoek duidelijk gebleken dat de basale zuursecretie niet bepaald wordt door, of bepalend is voor de plasma gastrinewaarden.

Van de nieren is bekend dat zij een groot aantal hormonen kunnen afbreken, waaronder het gastrine. Enkele klinische studies hebben ook verhoogde plasma gastrinewaarden aangetoond in de patienten zonder nieren en in patienten met een nierinsufficiënte. Hoewel in deze patienten vaker het optreden van gastritiden en gastro-intestinale bloedingen word beschreven, is er relatief weinig aandacht besteed aan de maagzuursecretie bij deze patienten, daar men uit een enkele publicatie had begrepen dat deze patienten altijd een zeer lage zuursecretie hadden door het neutraliserend effect van het hoge ammonia gehalte in de maag. In 3 groepen patienten, bestaande uit patienten zonder nieren die op transplantatie wachten, en uit patienten met een acute en een chronische nierinsufficiëntie werden basale plasma gastrinewaarden gemeten en zuursecretie studies verricht. In de 10 patienten zonder nieren, en in 8 patienten na niertransplantatie werden dagelijks plasma gastrinewaarden gemeten. Verder werden in 15 patienten met een chronische nierinsufficiëntie basale gastrinewaarden gemeten vóór en na hemodialyse, terwijl in de groep van 30 patienten met een acute nierinsufficiëntie dagelijks plasma gastrinewaarden werden bepaald totdat de nierfunctie zich had hersteld. Tevens werd in deze patienten een basale en een door pentagastrine gestimuleerde zuursecretie gemeten. Significant verhoogde basale plasma gastrinewaarden werden gevonden in al de patienten zonder nieren, in $50 \%$ van de patienten met een acute nierinsufficiëntie en in $55 \%$ van de patienten met een chronische nierinsufficièntie, hetgeen erop zou kunnen wijzen dat slechts in bepaalde aandoeningen van de nier ook het afbraakmechanisme van gastrine aangetast wordt. De verhoogde gastrinewaarden daalden tot de norm na niertransplantatie, wanneer de nier goed functioneerde en in acute nierinsufficiëntie wanneer de nierfunctie zich had hersteld.

Zuursecretie studies lieten in de 3 groepen patienten eigenlijk eenzelfde patroon zien van een zeer lage basale zuursecretie en hoge basale $\mathrm{pH}$ van de maag met een normale to verhoogde gestimuleerde zuursecretie. Dit toont aan dat tijdens de basale zuursecretie er waarschijnlijk een neutraliserend effect bestaat door het hoge ammonia gehal te van de maag, terwijl dit effect na stimulatie kennelijk niet optreedt, zeker niet in de patienten zonder nieren waar een zeer aanzienlijke zuursecretie werd gevonden. 


\section{Curriculum vitae}

Op 19 juni 1943 werd Rob Wesdorp te Amsterdam geboren. Hij bezocht aldaar het Spinoza Lyceum waar hij in 1960 het eindexamen HBS-B behaalde. In hetzelfde jaar werd de studie in de medicijnen aangevangen aan de Gemeentelijke Universiteit te Amsterdam, waar ook in 1969 het arts-examen werd behaald

In september 1969 begon hij met de opleiding Algemene Heelkunde in het St. Lucas Ziekenhuis te Amsterdam, onder leiding van Dr. W.H. Brummelkamp en Dr. J.M. Greep (later Dr. J.M. Greep, Dr. J.N. Keeman en Dr. H.W. Dicke). Deze opleiding werd in 1973 onderbroken voor een verblijf van anderhalf jaar in Boston (U.S.A.). In deze periode, 1973-1974, werkte hij als research en clinical fellow op de afdeling Chirurgie en het Chirurgisch Fysiologisch Laboratorium (hoofd Prof. J.E. Fischer) van het Massachusetts General Hospital en Harvard Medical School, alwaar de in dit proefschrift beschreven onderzoeken werden verricht.

Na terugkomst in Nederland in november 1974 werd de opleiding tot algemeen chirurg voortgezet in het St. Lucas Ziekenhuis te Amsterdam en sedert 1 december 1975 in het Ziekenhuis St. Annadal in Maastricht onder leiding van Prof.Dr. J.M. Greep en Dr. H.A.J. Lemmens.

Op 15 juli 1976 werd hij in het specialistenregister ingeschreven en is sedertdien werkzaam als Chef de Clinique op de afdeling Algemene Heelkunde, Ziekenhuis St. Annadal, Maastricht en als wetenschappelijk hoofdmedewerker aan de Rijksuniversiteit Limburg (Capaciteitsgroep Heelkunde). 